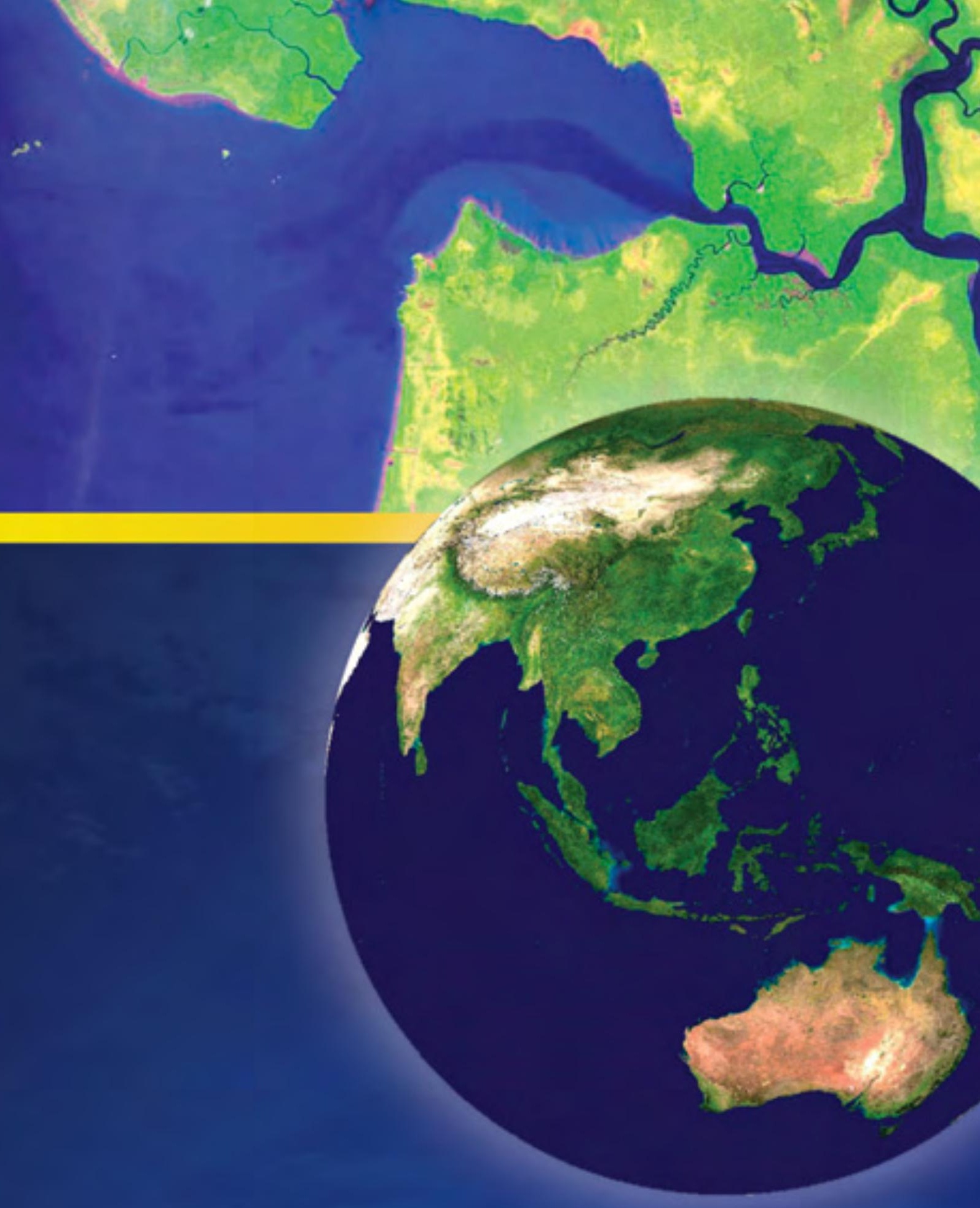

\title{
Determination of Eligible Lands for A/R CDM Project Activities and of Priority Districts for Project Development Support in Indonesia
}

Daniel Murdiyarso | Atie Puntodewo | Atiek Widayati $\mid$ Meine van Noordwijk 



\section{Determination of Eligible Lands for A/R CDM Project Activities and of Priority Districts for Project Development Support in Indonesia}

Daniel Murdiyarso

Atie Puntodewo

Atiek Widayati

Meine van Noordwijk 
Murdiyarso, D. et al.

Determination of eligible lands for A/R CDM project activities and of priority districts for project development support in Indonesia/by Daniel Murdiyarso, Atie Puntodewo, Atiek Widayati, Meine van Noordwijk. Bogor, Indonesia: Center for International Forestry Research (CIFOR), 2006.

39p.

ISBN: 979-24-4622-2

CAB Thesaurus: 1. carbon sequestration 2. greenhouse gases 3. emission 4. projects

5. selection criteria 6. land use 7. afforestation 8. forests 9. Indonesia I. Title II. Puntodewo, A. III. Widayati, A. IV. van Noordwijk, M. V. Clean Development Mechanism (Program).

\author{
(c) 2006 by CIFOR \\ All rights reserved. Published in 2006 \\ Printed by Inti Prima Karya, Jakarta \\ Design and layout by Catur Wahyu \\ Cover photos by Daniel Murdiyarso and Ramadhani Achdiawan \\ Cover maps* by Mohammad Agus Salim
}

*Globe ESRI World Cloud Free generated from 2001 NASA Moderate Resolution Imaging Spectroradiometer (MODIS) satellite images enhanced with shaded relief imagery derived from the USGS GTOPO30 digital elevation data and Satellite imagery generated from Landsat 7 ETM Path 121 Row 061 acquired on 22 June 2001 and Landsat 7 ETM Path 128 Row 058 acquired on 2 February 2002, originate by Eros Data Center - U.S. Geological Survey (EDC-USGS).

\author{
Published by \\ Center for International Forestry Research \\ Jl. CIFOR, Situ Gede, Sindang Barang \\ Bogor Barat 16680, Indonesia \\ Tel.: +62 (251) 622622; Fax: +62 (251) 622100 \\ E-mail: cifor@cgiar.org \\ Web site: http://www.cifor.cgiar.org
}




\section{Contents}

List of Appendices $\quad$ iv

List of Figures $\quad$ v

List of Tables $\quad$ vi

Preface vii

Abstract viii

1. Introduction 1

2. Materials and Methods 2

2.1 Indonesian forest cover 2

2.2 'Hard' selection criteria of Kyoto eligible lands 3

2.3 'Soft' selection criteria of Kyoto eligible lands 5

3. Relationships among the quantitative indicators 9

4. District Typologies $\quad 12$

4.1 A/R CDM eligible land area by district $\quad 12$

4.2 Meeting sustainable development objectives 12

$\begin{array}{ll}\text { 4.3 Applying criteria for prioritising districts } & 12\end{array}$

4.4 Clustering of districts based on similarity 13

5. Further Considerations 16

$\begin{array}{ll}\text { References } & 17\end{array}$ 


\section{List of Appendices}

1. CDM eligible land by district $\quad 18$

2. Population density and Human Development Index by district 25

3. Fire risk in CDM eligible land by district 31

4. Land cover classification at $1 \mathrm{~km}$ nominal spatial resolution for Indonesia according to the IGBP legend based on imagery of the 1992-1993 period

5. Land cover classification for Indonesia's islands (excluding the seas) according to the IGBP legend

6. Workbook for applying specified prioritisation criteria to a list of district level statistics of land cover, fire frequency, population density and Human

Development Index 


\section{List of Figures}

1. The Indonesian forest cover before 1990

2. The Indonesian forest cover after 1990

3. Stepwise procedures to select eligible land using 'hard' and 'soft' criteria 4

4. Population density data for Indonesia, classified as low $\left(<10\right.$ persons $\left./ \mathrm{km}^{2}\right)$, lower-medium (10-100 persons $\left./ \mathrm{km}^{2}\right)$, upper-medium (100-300 persons $\left./ \mathrm{km}^{2}\right)$ and high $\left(>300\right.$ persons $\left./ \mathrm{km}^{2}\right) \quad 6$

5. Human Development Index by district for Indonesia (low < 50; lower-medium 50-66; upper-medium 66-79; and high > 80)

6. Indication of frequency of fire (hot spots) on lands that were deforested before 1990

7. Relationship between district-level population density (number of persons per square kilometer; a logarithmic scale is used) and the fraction of the district (Kabupaten) with (natural) forest cover at the start of 1990 (to the best of our knowledge), the fraction in paddy rice fields, the Human Development Index and an indicator of fire frequency (hot spots) over recent years

8. Exploration of relationships among the 'residues' (differences between 1990 forest cover and that expected on the basis of the 2002 population density and a logarithmic relationship derived from Fig. 7) and the paddy rice fraction, Human Development Index and fire frequency indicator

9. Relationships among Human Development Index, Fire Frequency Index and the forest fraction of districts in Java, Sumatra, Kalimantan and Nusa Tenggara

10. Districts prioritised for CDM based on the criteria: minimum $15 \%$ of eligible lands in the district, population density between 10 and 100 persons $/ \mathrm{km}^{2}$, HDI below 65

11. Three clusters suggested representing districts with degrees of similarity 


\section{List of Tables}

1. Coefficients of simple linear regression equations among forest fraction $(y)$ of districts in Java, Sumatra, Kalimantan and (Bali +) Nusa Tenggara, the Human Development Index (HDI) and the Fire Frequency Index, shown in Figure 3

2. Districts that meet the 'priority' criteria of HDI below data set mean, population density between 10 and 100 persons $/ \mathrm{km}^{2}$ and at least $15 \%$ of district eligible 


\section{Preface}

The Government of Indonesia has ratified the Kyoto Protocol and is preparing to engage projects under the Clean Development Mechanism (CDM). Since Indonesia has no experience in this the technical assistance offered by the Asian Development Bank (ADB) was welcomed (Project code: TA 4137-INO). The overall goal of the ADB-Technical Assistance project is to help the Government of Indonesia work with local stakeholders to prepare projects that (i) promote sustainable forest development, and (ii) can earn Certified Emission Reduction (CER) units for the reduction of greenhouse gas (GHG) emissions under the CDM of the Kyoto Protocol.

The Center for International Forestry Research (CIFOR), in collaboration with the World Agroforestry Centre (ICRAF), was asked to support selection, evaluation and development of CDM projects according to the Kyoto Protocol's modalities and procedures. CIFOR and ICRAF also took the lead in modeling at least two pilot districts to support baseline and scenario evaluation to be included in the Project Design Document (PDD).

This document reports on the selection criteria and results for further consideration by the Government of Indonesia in consultation with other stakeholders, including local governments and civil societies. This is in line with the immediate purpose of the technical assistance, which is to develop the capacity of the Government and Indonesian stakeholders for pilot testing carbon sequestration projects under the CDM that will strengthen understanding of the processes, implications, and potential applications of the CDM. It is expected that this document will help both local hosts and investors prepare the necessary data, documents, and human resources to fully implement the projects.

We would like to take this opportunity to gratefully acknowledge Winrock International and the Land Management Grant College of Bogor Agricultural University for their collaboration as consultants to the Government of Indonesia, especially in the process of stakeholder consultations and the provision of necessary data and information. Critical inputs were also given by the National Project Director and the Steering Committee.

February 2006

CIFOR-ICRAF Team 


\section{Abstract}

Based on the best available remote sensing data from before 1990, the total area of formally eligible lands in Indonesia for the afforestation and reforestation (A/R) Clean Development Mechanism (CDM) activities under the Kyoto protocol is about $46 \mathrm{M}$ ha. Priorities for assistance in the development of A/R CDM project activities may use criteria based on (i) the Human Development Index (HDI), which is focused on districts with below-average HDI; (ii) population density, which is in the range where the land/labour ratio is conducive to profitable tree-based farming systems; and (iii) Fire Risk Index (FRI).

Overall the lists for Java, Sumatra, Kalimantan, Nusa Tenggara, Sulawesi, Molluca, and Papua that meet these criteria involve 302 Districts, $195 \mathrm{M}$ ha of total area in the districts with $48 \mathrm{M}$ ha of 'eligible Kyoto lands' and $158 \mathrm{M}$ people and a mean HDI of 64.7. The mean of district-level population density is 293 persons $/ \mathrm{km}^{2}$ and the mean FRI is 0.086 .

When a 'default' setting of the criteria (minimum 15\% of eligible lands in the district, population density between 10 and 100 persons $/ \mathrm{km}^{2}$, HDI below 65), we obtain a priority list of 60 districts ( $20 \%$ of the total). This priority lists involves $46 \mathrm{M}$ ha in the districts (24\% of the total) with $19 \mathrm{M}$ ha of 'Kyoto lands' ( $40 \%$ of the total) and $19.5 \mathrm{M}$ people ( $12 \%$ of the total) and a mean HDI of 62.9 (reflecting the 'pro-poor' prioritisation), mean of district-level population density of 53 persons $/ \mathrm{km}^{2}$ (the larger districts tend to have lower densities) and mean FRI of 0.135 (60\% higher than for the set as a whole). 


\section{Introduction}

Clean Development Mechanism (CDM) project activities have to meet a number of requirements to ensure that they truly support 'development' for the people living in the area, that they are 'clean' and that they follow proper procedures. Technically, eligibility of lands for the implementation of CDM project activities requires compliance with the international rules and national regulations and priorities. In the first commitment period of the Kyoto Protocol, Land-use, Land-use Change and Forestry (LULUCF) activities under the CDM are limited to afforestation and reforestation. In this connection, the Conference of Parties of the United Nations Framework Convention on Climate Change (UNFCCC) provided the definition of afforestation and reforestation under the provision of Decision 17/CP.7, where:

\section{'Afforestation' is the direct human-induced conversion of land that has not been forested for a period of at least 50 years to forested land through planting, seeding andlor the human- induced promotion of natural seed sources. While}

\begin{abstract}
'Reforestation' is the direct human-induced conversion of non-forested land to forested land through planting, seeding andlor the humaninduced promotion of natural seed sources, on land that was forested but that has been converted to non-forested land. For the first commitment period, reforestation activities will be limited to reforestation occurring on those lands that did not contain forest on 31 December 1989.
\end{abstract}

The definitions of 'forest' and 'tree' in this regard are left to the national authorities, but require consistency. A strict definition of forest that only includes natural old-growth forest will ensure that a large area of land is 'eligible', but disqualifies most 'reforestation' activities as not restoring land to the 'forest' condition. A looser definition substantially increases the scope for 'reforestation' but reduces 'eligibility'. In practice, Indonesia has chosen a definition of forest that is based on at least 30\% of crown cover by trees at least $5 \mathrm{~m}$ high. This definition means that cassava fields (a perennial at least $2 \mathrm{~m}$ high) and monoculture coffee or tree gardens are excluded, but coffee gardens with 30\% crown cover of emergent trees are 'in'. Rubber, oil palm and industrial timber plantations are effectively included, as are most agroforestry systems where timber or fruit trees are grown in combination with annual food crops or grass as fodder. Once lands are classified as 'eligible', the next steps in the CDM process require estimates of actual $\mathrm{C}$ sequestration, and will thus differentiate among these various reforestation options.

Back-dated quality-controlled datasets are crucial to determine eligible lands to carry out CDM project activities under the Kyoto Protocol. They should use the same 'forest'/'non-forest' delineation as will be used for judging acceptability of reforestation activities. This report provides a spatially explicit identification of 'eligible lands' for Indonesia, acknowledging the limitations of maps that used a 'natural forest' definition that excludes much of the plantations, agroforest and trees in agroforestry landscapes. Higher-resolution data within selected candidate project areas will have to add these land cover types to the consideration.

Further biophysical and socio-economic data and information within administrative boundaries of districts (Kabupaten) and province were analysed to help in the assessment of the suitability of reforestation for the local economy and in the setting of priorities for support in CDM project development. These data are only a first step in a process where project developers will have to consult local government and other stakeholders as part of a process that is meant to ensure 'clean development' and guard against the imposition of land use restrictions on rural poor households. 


\section{Materials and Methods}

\subsection{Indonesian forest cover}

Two kinds of spatial datasets were used as materials to determine eligible lands for $\mathrm{A} / \mathrm{R} \mathrm{CDM}$ project activities. The World Conservation Monitoring Centre (WCMC 1996) originated the first dataset, which represents information on the tropical moist forest in Indonesia before 1990 using very broad vegetation type categories. The information was gathered from various sources including:

- Three thematic maps $(1: 250,000)$ of land systems and land suitability, land use, and land status produced by the Regional Physical Planning Programme for Transmigration (RePPProT) project. The project was started in 1984 in association with the National Centre for Co-ordination of Surveys and Mapping (BAKOSURTANAL). The dates of the maps are: Sumatra, 1988; Java and Nusa Tenggara, 1989; central Kalimantan, 1985; south, west and east Kalimantan, 1987; Sulawesi, 1988; Moluccas, 1989; and Irian Jaya, 1986.

- Remote sensing imagery for Indonesia used in preparing the maps included air photography, Landsats 2, 3, 4 and 5, SPOT, and radar, including SAR and SLAR. Areas covered, dates and scales varied greatly and full details are available from BAKOSURTANAL and RePPProT's regional reviews (RePPProT 1990).

The legend includes eleven forest categories:

- Upper montane forest

- Lower montane forest

- Needleleaf forest

- Deciduous/semi-deciduous forest

- Lowland evergreen broadleaf rain forest

- Semi-evergreen broadleaf forest

- Disturbed natural forest

- Freshwater swamp forest

- Mangrove

Forest logged but left to regenerate either with or without silvicultural treatment was not distinguished from pristine forest in this dataset. Thus, this dataset does not distinguish the areas of recently logged

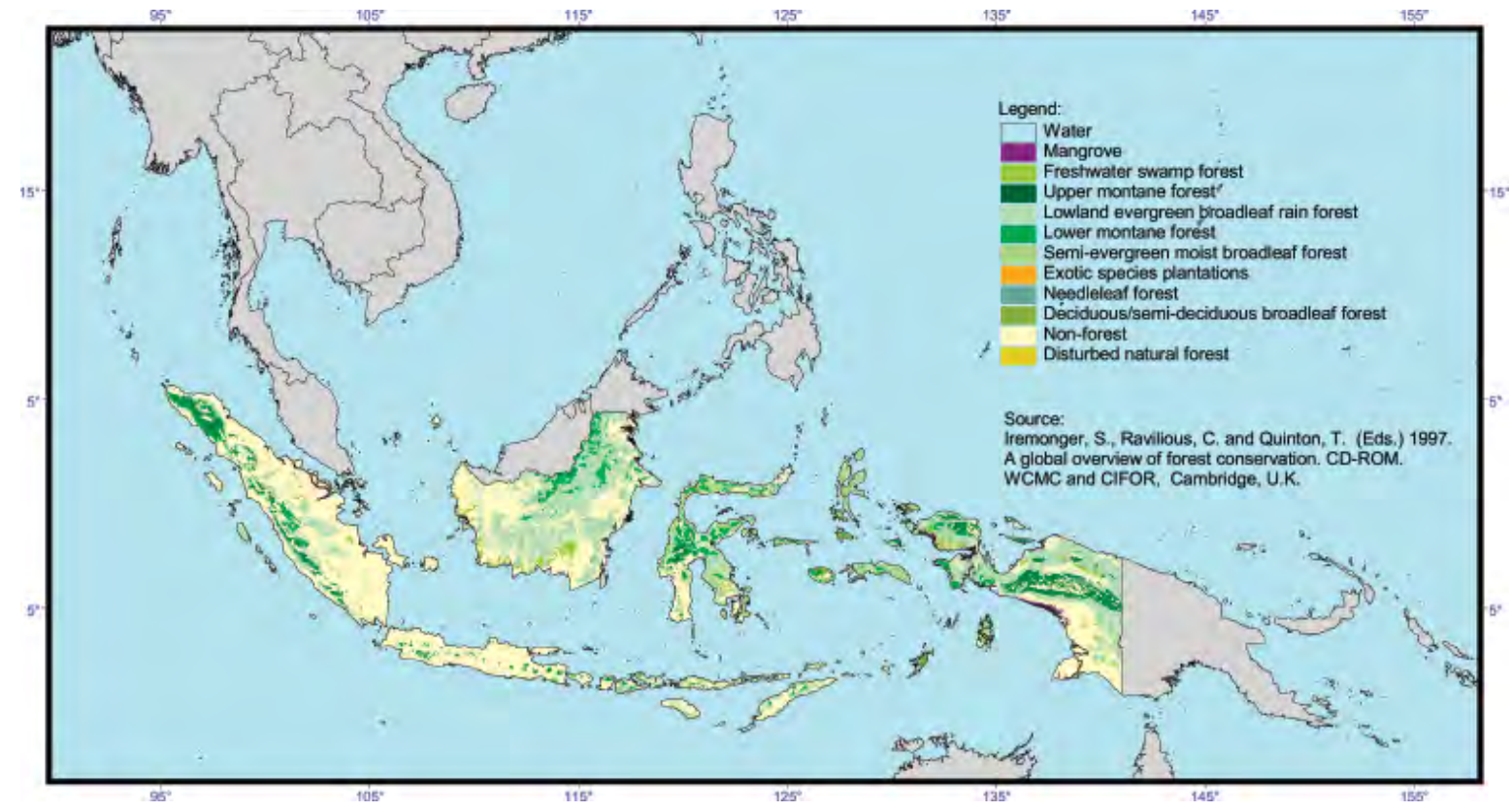

Figure 1. The Indonesian forest cover before 1990 (Iremonger et al. 1997) 
forest, which were identified by RePPProT. Areas that RePPProT showed as converted from forestry to other land uses are clearly identified.

In addition, there are two non-forest categories, which are water bodies and non-forest lands. The summary of forest cover before 1990 is shown in Figure 1.

The second dataset represents the forest cover after 1990. These data were obtained from the Forest Cover Map of Insular Southeast Asia produced by the Tropical Ecosystem Environment observation by Satellite (TREES) project of the EU-Joint Research Center (Stibig et al. 2002). The map was based on the SPOT4 VEGETATION satellite imageries with a spatial resolution of $1 \mathrm{~km}$.

The high spectral resolution of SPOT imageries could identify land-cover type with greater accuracy. However, the coarse spatial resolution has to be traded off by validating them with LANDSAT-TM products, which have a resolution of $30 \times 30 \mathrm{~m}^{2}$.

The TREES legend includes nine categories of landcover, including non-forest:

- Evergreen montane forest

- Closed evergreen forest

- Dense evergreen forest

- Swamp forest
- Mangrove forest

- Mixed bush and shrubs

- Cropland

- Burnt area

- Non-forest

Based on the map produced by TREES project the Indonesian forest cover after 1990 is summarised in Figure 2 .

\section{2 'Hard' selection criteria of Kyoto eligible lands}

The term 'hard' does not connote the difficulty in accessing the data but simply expresses the nonnegotiable nature of the agreed rules and modalities. The following criteria are considered 'hard' because of the following reasons:

- The land should comply with the definitions of forest, afforestation, and reforestation

- The data are spatially explicit and compatible with GIS processes

- Non-spatial data may be used as long as they represent an identifiable domain that may be deducted from or added to the values derived from spatial data

It is necessary, therefore, to compare land-cover maps dated before and after 1990 as well as to overlay other working maps and data concerning land-uses

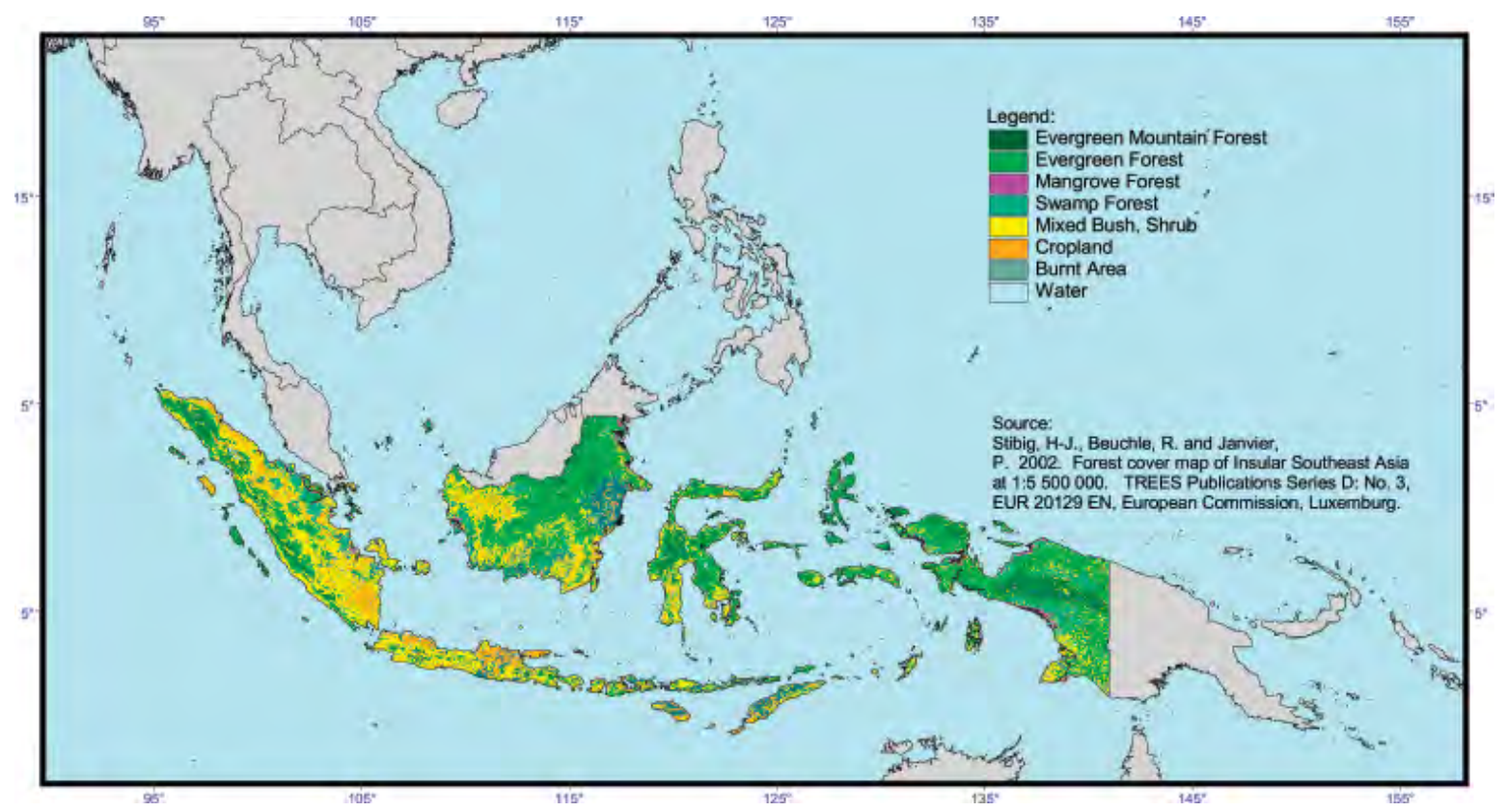

Figure 2. The Indonesian forest cover after 1990 (Stibig et al. 2002) 
and administrative jurisdictions. The Kyoto eligible lands could then be presented, for example, by district. The procedure of determining eligible lands using 'hard' criteria is summarised in Figure 3. The process is then followed by 'soft' selection criteria, which will be described below.

\subsubsection{Land cover changes before and after 1990}

After excluding water bodies and overlaying the WCMC and TREES maps and based on the definitions of afforestation and reforestation, the CDM project activities may be carried out in areas which are non-forest and remain unchanged after
1990 , and areas which are under the following categories of change:

- From non-forest to mixed bush and shrubs

- From non-forest to cropland

The mixed bush and shrubs class contains all nonforest vegetation cover with a more or less evergreen appearance. This class may include natural vegetation cover but also mature plantation coconut, oil-palm and rubber. Under the forest definition chosen by Indonesia in fact at least part of the lands in this category are considered to be 'forest'. Further studies with higher-resolution data will be needed to clarify the status of these lands.

\section{Site Selection Procedure for CDM}

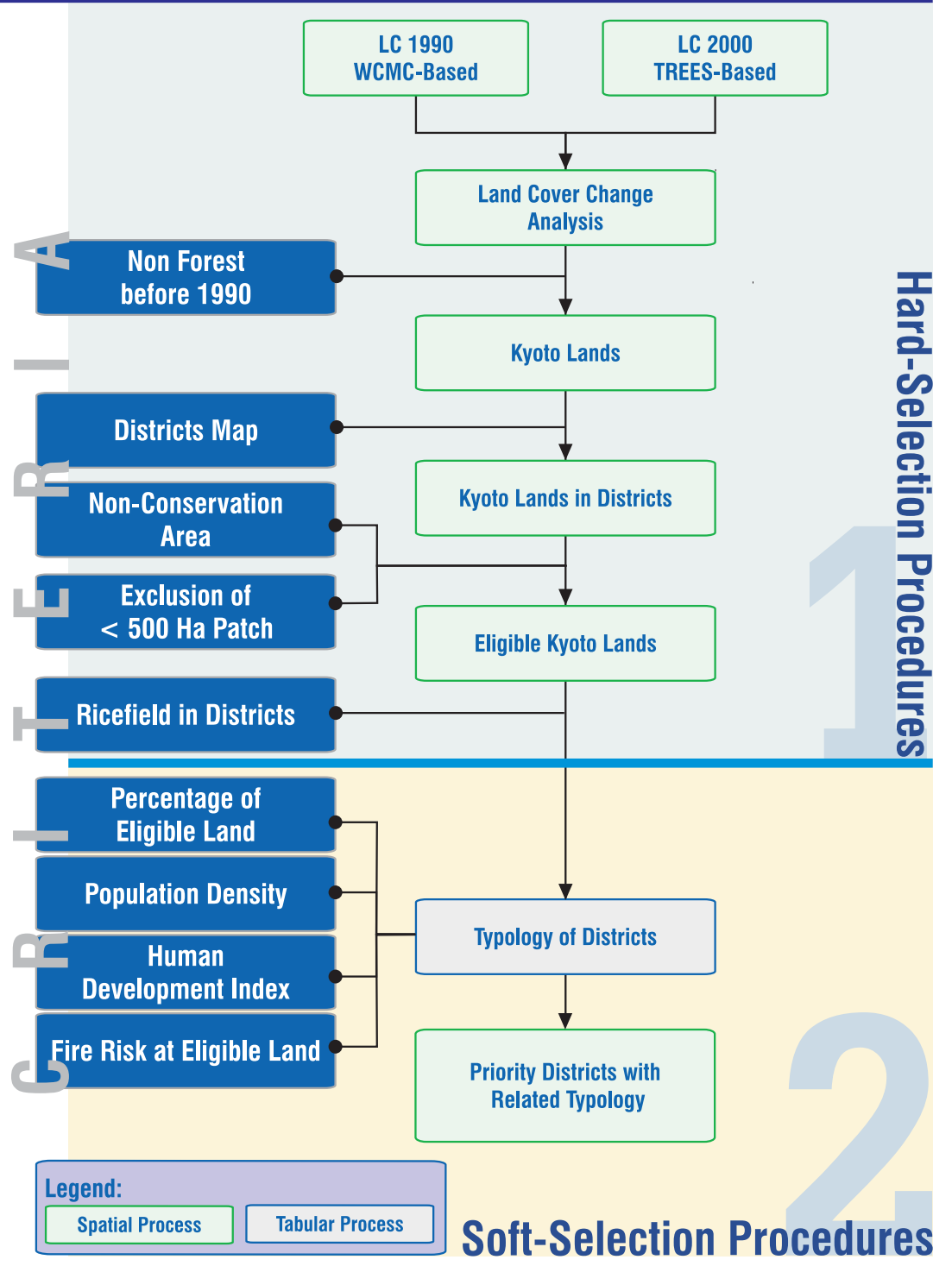

Figure 3. Stepwise procedures to select eligible land using 'hard' and 'soft' criteria 
The cropland class includes more intensively cultivated areas, such as rice fields. These will be treated separately using agricultural statistics data available at district level. Parts of this class displays stages of bare soil. Early stages of tree crop plantations will be included in this category as well.

\subsubsection{Conservation and production areas}

The Agency of Forest Planning of the Ministry of Forestry produced a map of forest land-use by consensus, known as TGHK (Ministry of Forestry 1999), which indicates the following categories:

- Protection forest

- Nature Reserve

- Production forest

- Limited production forest

- Convertible production forest

By definition the first two categories do not comply with the Kyoto rules and technically speaking will not produce significant additionality. Therefore, they are excluded from the map of land cover change before and after 1990 .

\subsubsection{Small patches}

Numerous small patches of eligible land are usually found after such overlaying. All patches smaller than 500 ha of eligible land will be excluded, because even with a relatively high mean annual increment of biomass (say, $10 \mathrm{~m}^{3} /$ year), such patches would not significantly contribute meaningful additionality or carbon sequestration. One may argue that they could be combined to form a substantially 'large' aggregate of eligible lands. This may be true in terms of physical sum, but it is highly likely that one would face rather complicated institutional and regulatory arrangements. Such an aggregate also probably would not be cost-effective as it usually entails high transaction costs.

\subsubsection{Area of rice fields}

Large areas under non-forest or cropland categories may be dominated by irrigated or rainfed rice fields, especially on Java, Bali, southern Sumatra and Sulawesi. They will definitely not be converted into carbon sequestering land, although they are eligible by definition. As the data of rice field area are available at district level, the area will be deducted from the spatial data of eligible land after incorporating district boundary.
It would then be possible to show the fractions of eligible land and rice fields by district. Such information may be useful in order to provide information for general land-use planning at the district level.

\section{3 'Soft' selection criteria of Kyoto eligible lands}

'Soft' criteria (not legally constrained, negotiable indications of priority) consider the possibility of including or excluding particular criteria or findings, which may or may not be spatially explicit but relevant to the national and local initiatives. Among these criteria population density, human development index and fire risk were selected. They are well documented and highly deserved from the perspective of sustainable development objectives.

\subsubsection{Population density}

District level data collated by the National Statistical Agency are used to calculate population density. The distribution of population density is highly skewed towards districts on Java. It is argued that $\mathrm{A} / \mathrm{R} \mathrm{CDM}$ project activities will likely have to support high population densities in terms of their labor requirement. A density of 60 persons/ $\mathrm{km}^{2}$ was found by ICRAF to be the highest where people can find a paid job in caring for the trees in community rubber plantation. It is also considered that C-stock increasing land use is not an 'urban' type of employment. Based on these arguments the categories of population density are proposed to consist of four classes:

$$
\begin{aligned}
\text { Low: } & <10 \text { persons } / \mathrm{km}^{2} \\
\text { Lower-medium: } & 10-100 \text { persons } / \mathrm{km}^{2} \\
\text { Upper-medium: } & 101-300 \text { persons } / \mathrm{km}^{2} \\
\text { High: } & >300 \text { persons } / \mathrm{km}^{2}
\end{aligned}
$$

Further it is worth to consider a population density of 100 persons $/ \mathrm{km}^{2}$ as the threshold to determining the appropriateness of implementing CDM project activities. Thus, districts with population density of more than 100 persons $/ \mathrm{km}^{2}$ should not be prioritised and vise versa.

Figure 4 shows the distribution of population based on the density class category by district. It is obvious that Java is the most densely populated island. In some districts it has well above 1000 people $/ \mathrm{km}^{2}$. 


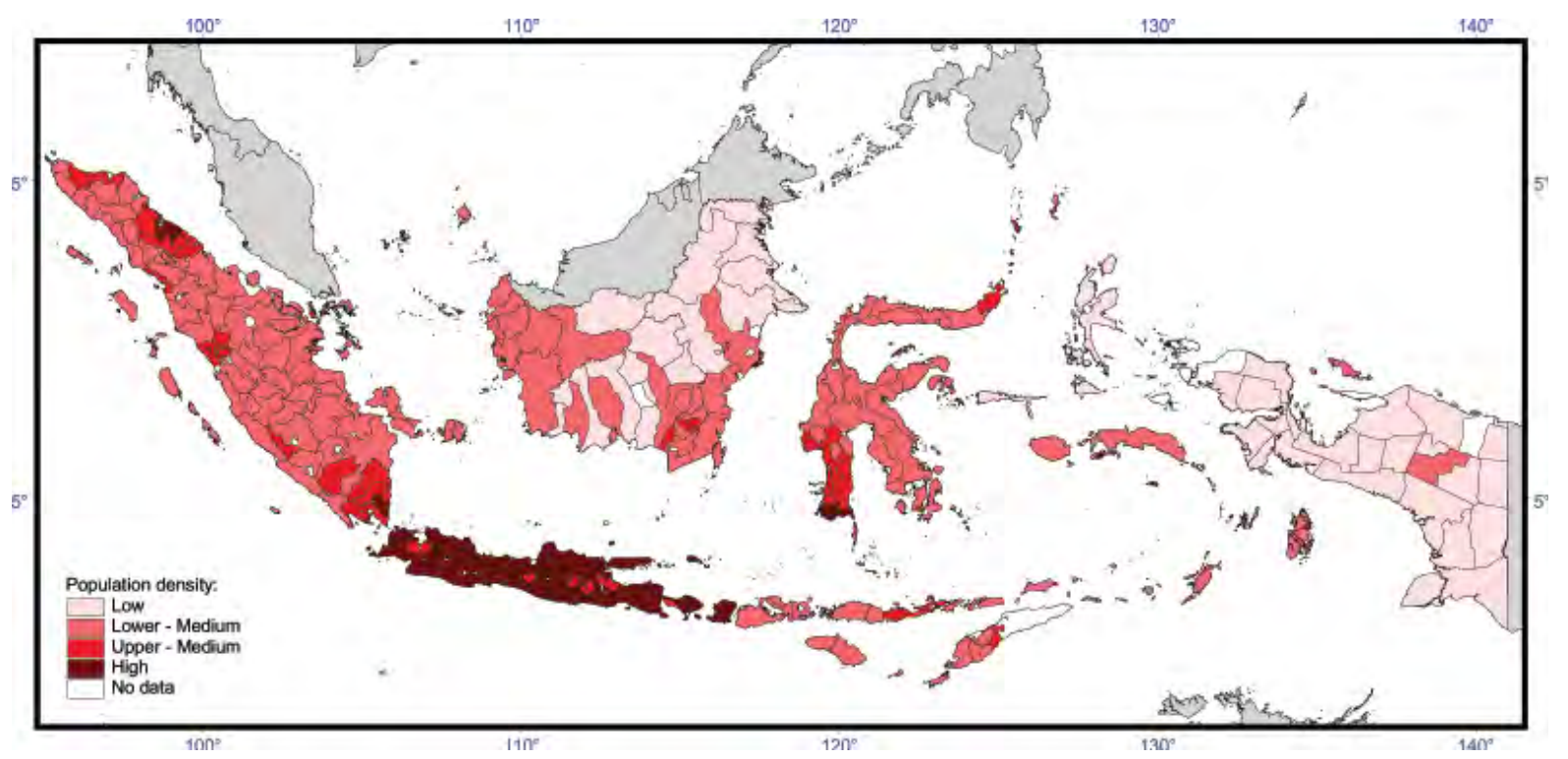

Figure 4. Population density data for Indonesia, classified as low ( $<10$ persons $\left./ \mathrm{km}^{2}\right)$, lower-medium (10-100 persons $\left./ \mathrm{km}^{2}\right)$, upper-medium (100-300 persons $\left./ \mathrm{km}^{2}\right)$ and high (> 300 persons $\left./ \mathrm{km}^{2}\right)$

It should be noted that the missing data in some islands is due to statistical discrepancies after the recent split of some districts.

\subsubsection{Human Development Index}

The Human Development Index (HDI) is considered a better indicator of development equity and people's welfare than per capita income as it measures not merely economic growth. The HDI is based on three components: longevity, as measured by life expectancy at birth; educational attainment, as measured by the combination of adult literacy rate and mean years of schooling; and standard of living, as measured by adjusted per capita expenditure. The index is defined as the simple average of the indices of those three components:

$$
H D I=1 / 3\left(\text { Index } X_{1}+\operatorname{Index} X_{2}+\text { Index } X_{3}\right)
$$

where $\mathrm{X}_{1}, \mathrm{X}_{2}$ and $\mathrm{X}_{3}$ are longevity, educational attainment and standard of living, respectively.

Longevity is measured by using the indicator of life expectancy at birth $\left(e_{0}\right)$. The $e_{0}$ is related to the infant mortality rate (IMR). The estimation of IMR at provincial level is calculated based on data series from the 1971, 1980 and 1990 censuses, and pooled data of the 1995 survey between censuses (SUPAS) and the 1996 national socio-economic survey (SUSENAS).
The component of educational attainment is measured by using two indicators-literacy rate and mean years of schooling. The literacy rate is defined as the proportion of population aged 15 years or older who are able to read and write, in Latin or other script, as a percentage of this age group. Mean years of schooling is defined as the average years of formal schooling attended among the population aged 15 years or older.

As a proxy of standard of living the adjusted real per capita expenditure is used after taking into account the Consumer Price Index (CPI) and the Purchasing Power Parity (PPP) for each region as the relative price of a certain bundle of commodities.

A report by BAPPENAS and UNDP (2004) grouped the HDI into four categories:

$$
\begin{aligned}
\text { Very poor: } & <50 \\
\text { Poor: } & 50-66 \\
\text { Medium: } & 66-80 \\
\text { Not poor: } & >80
\end{aligned}
$$

The gap between the current index and 100 represents the human development 'shortfall'-the distance that each district needs to travel. The 'very poor' and 'poor' districts have a below-average HDI, whereas the HDI of 'medium' districts is above average. There was no district that fell under 'not poor'. 


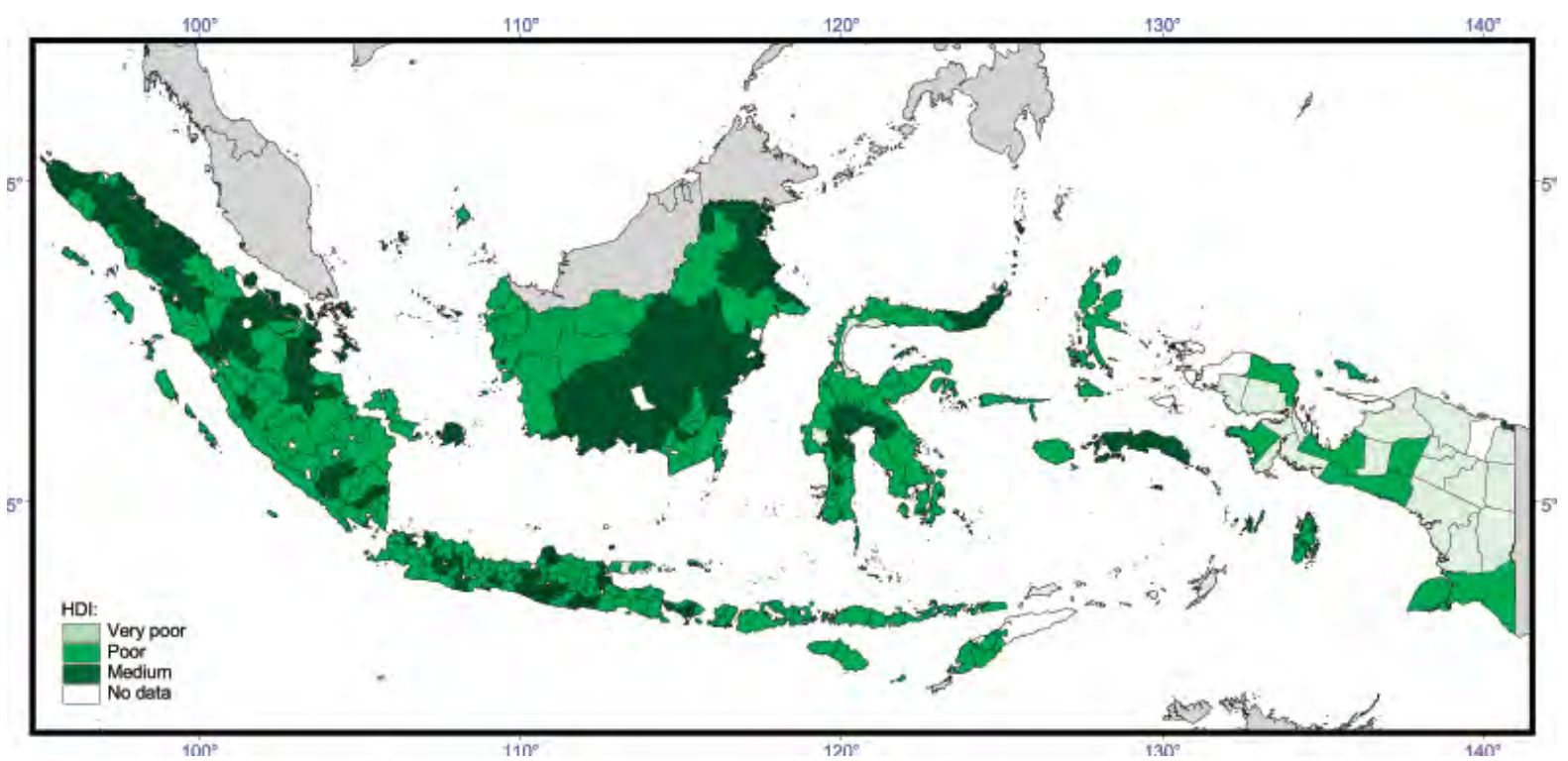

Figure 5. Human Development Index by district for Indonesia (low < 50; lower-medium 50-66; upper-medium 66-79; and high > 80)

Figure 5 shows that HDI categories by district are distributed quite evenly across the archipelago. It also demonstrates that Papua has only poor and very poor categories.

\subsubsection{Fire Risk Index}

Fire risk is associated with fire frequency between El Nino events. It is estimated from the frequency of hot spot occurrence observed by the NOAAAVHRR satellite between 1998 and 2004. Hot spot frequency is grouped into three categories:

$$
\begin{aligned}
\text { Low: } & <6 \\
\text { Medium: } & 7-12 \\
\text { High: } & 13-19
\end{aligned}
$$

Since the NOAA satellite resolution is $1 \mathrm{~km}^{2}$, each hot spot was buffered for this pixel, meaning that one hot spot represents an area of $1 \mathrm{~km}^{2}$. In order to produce a more spatially meaningful representation, the fraction of affected area can be calculated as ratio of the buffered area for each category and the area of the district.

$$
\begin{aligned}
\text { LFraction }= & \text { area affected by low hot spot } \\
& \text { frequency/district area } \\
\text { MFraction }= & \text { area affected by medium hot spot } \\
& \text { frequency/district area } \\
\text { LFraction }= & \text { area affected by low hot spot } \\
& \text { frequency/district area }
\end{aligned}
$$

Fire Risk Index (FRI) can be defined as the sum of fractions of areas affected by each fire frequency category multiplied by weighting factors for each category. The factors were arbitrarily chosen as 1, 3 and 10 for the low, medium and high frequencies, respectively.

$F R I=\left(1^{*}\right.$ LFraction $)+\left(3^{*}\right.$ MFraction $)+\left(10^{*}\right.$ HFraction $)$

The weighting factors may be adjusted depending on the level of risk management capability of the respective implementing units. Based on the range of the indices, they may be grouped into the following categories:

Low: $<0.05$

Medium: $0.05-0.20$

High: $>0.20$

A low FRI means few fire incidents, a medium FRI corresponds with an intermediate number of fire incident and a high FRI describes a situation of having elevated risk of fires.

Figure 6 shows the distribution of FRI, which is highest in the provinces of Riau, South Sumatra and Lampung, West Kalimantan, Central Kalimantan and South Kalimantan. 


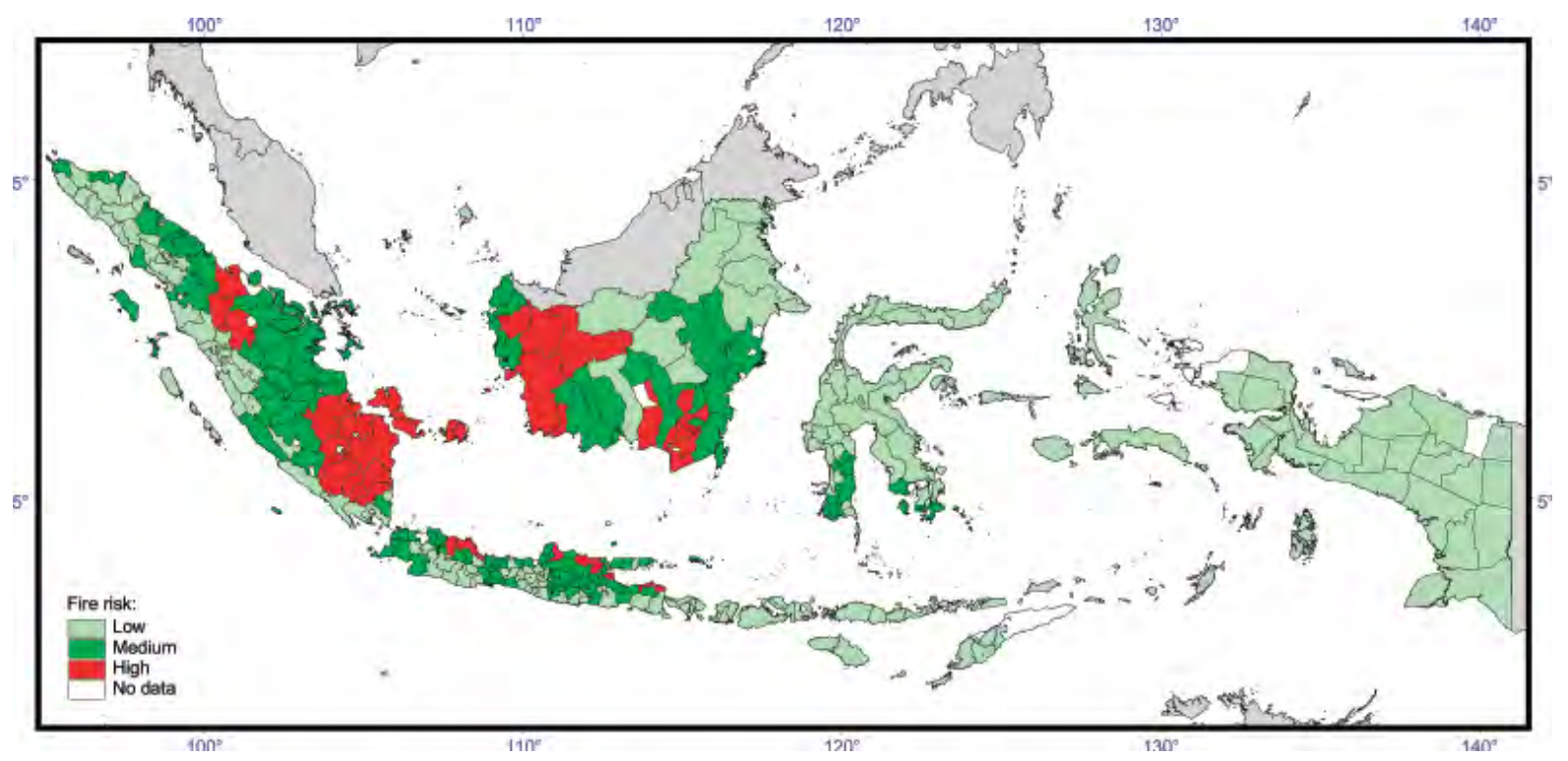

Figure 6. Indication of frequency of fire (hot spots) on lands that were deforested before 1990 


\section{Relationships among the quantitative indicators}

In order to indicate the distribution of eligible land across the districts the forest fraction is defined as the ratio of 'forested' area to district area. Similarly, the rice paddy fraction is the ratio of rice field area to district area. The first task is to explore the (statistical) relationships among these data (Figure 7).

Population density clearly differentiates the islands. Java has the highest population density and Kalimantan the lowest, while those of Sumatra and Nusa Tenggara are intermediate. In an Indonesiawide (at least for the islands included in the analysis) comparison population density has clear relationships (negative and positive, respectively) with forest cover and paddy rice fields. The data for Java and Kalimantan are confined to the upper and lower range, respectively, with Sumatra and Nusa Tenggara in intermediate position. Within each of these islands (island groups) the overall relationship is still maintained, but generally more weakly.

The data on HDI suggests that the poorest districts (lowest HDI) are found on Java and Nusa Tenggara, while most of the districts in Sumatra and Kalimantan
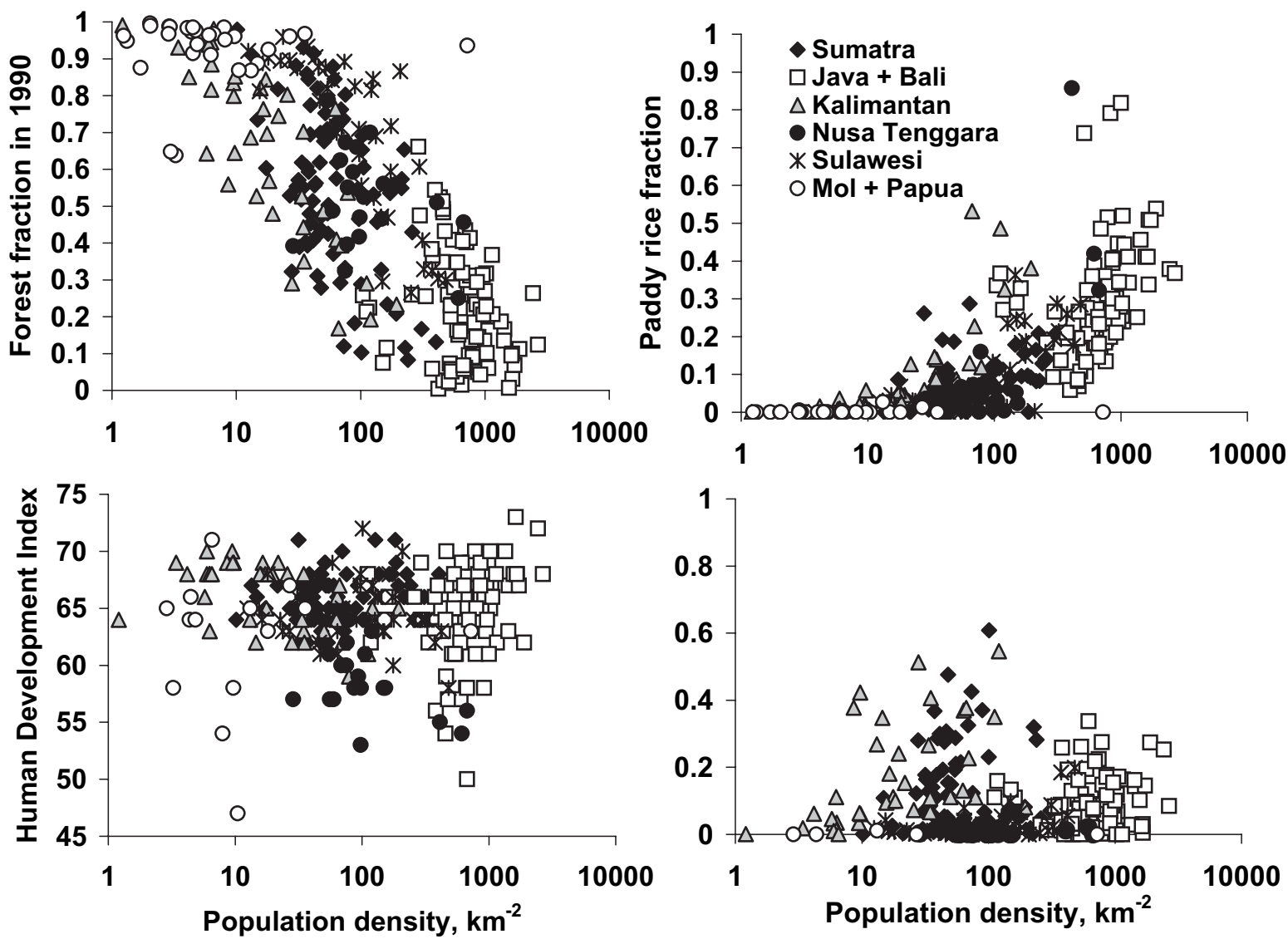

Figure 7. Relationship between district-level population density (number of persons per square kilometer; a logarithmic scale is used) and the fraction of the district (Kabupaten) with (natural) forest cover at the start of 1990 (to the best of our knowledge), the fraction in paddy rice fields, the Human Development Index and an indicator of fire frequency (hot spots) over recent years 
are close to the overall mean value of 65 . The hot spot frequency is highest in parts of Sumatra and Kalimantan as well as in areas on Java. Statistically, the strongest correlation is that between population density and the forest fraction:

$$
\begin{gathered}
\text { ForestFraction }=-0.1239 \operatorname{Ln}(\text { PopDens })+1.0678 \\
\qquad\left(\mathrm{R}^{2}=0.607, \mathrm{n}=224\right)
\end{gathered}
$$

Analysis of the residues (difference between the actual forest fraction of a district and the value expected on the basis of this equation) shows no relationship with the rice field fraction and the Human Development Index, but fire frequency explains part of the negative residues (Figure 8 ).
The relationship between forest fraction and HDI is weak when we consider the data set as a whole (Figure 9; Table 1). But when the data are analysed per island (group) an interesting pattern emerges: for the 'outer islands' of Kalimantan, Nusa Tenggara and Sumatra the slope is positive (more forest is associated with a higher HDI), while for Java the relationship is negative (higher HDI is associated with less forest). In both cases a forest fraction of about $30 \%$ is associated with the lowest HDI. It will be interesting to explore this further for components of the HDI, as the aggregated relationships are weakly defined. It suggests, however, that Sumatra is intermediate between the other outer islands and Java-as it is in many other respects.
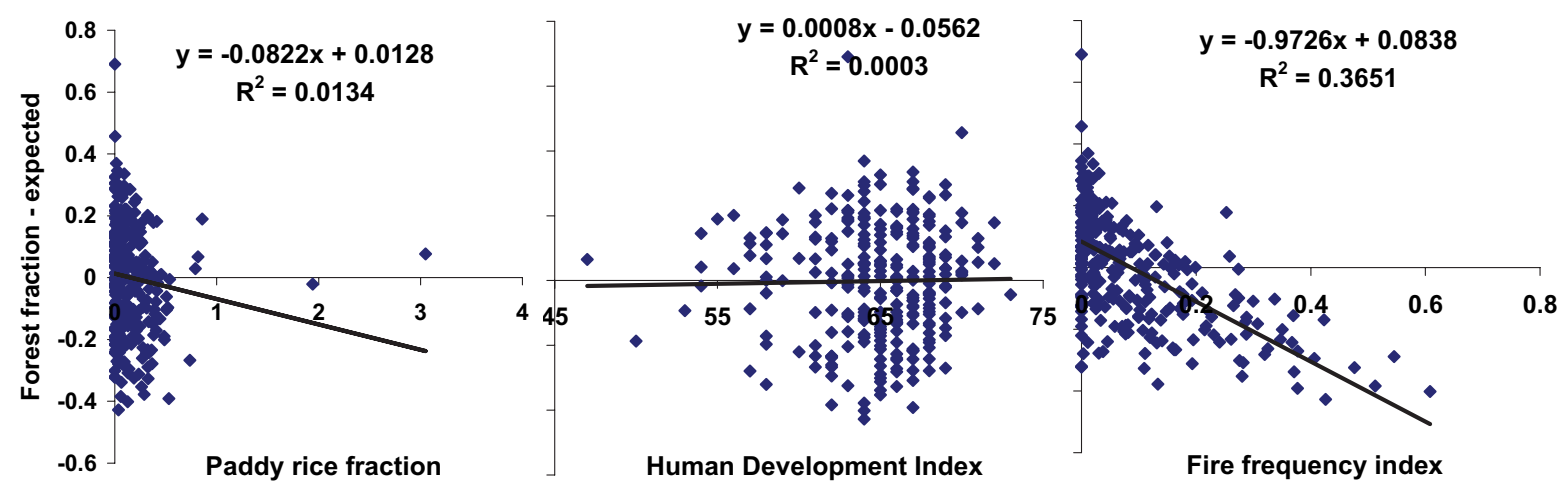

Figure 8. Exploration of relationships among the 'residues' (differences between 1990 forest cover and that expected on the basis of the 2002 population density and a logarithmic relationship derived from Fig. 7) and the paddy rice fraction, Human Development Index and fire frequency indicator
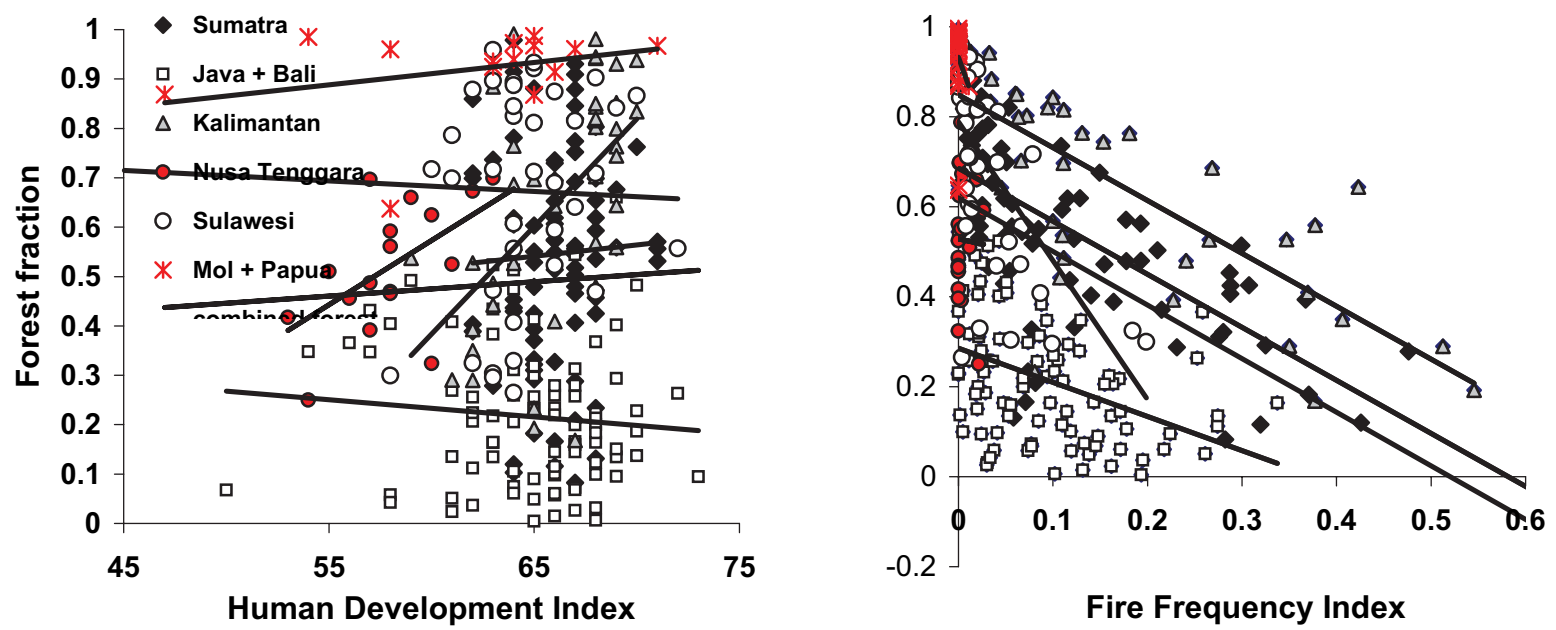

Figure 9. Relationships among Human Development Index, Fire Frequency Index and the forest fraction of districts in Java, Sumatra, Kalimantan and Nusa Tenggara 
Table 1. Coefficients of simple linear regression equations among forest fraction ( $y$ ) of districts in Java, Sumatra, Kalimantan and (Bali +) Nusa Tenggara, the Human Development Index (HDI) and the Fire Frequency Index, shown in Figure 3

\begin{tabular}{lcccc}
\hline & Human Development Index (HDI) & $\mathbf{R}^{2}$ & Fire Frequency Index (FFI) & $\mathbf{R}^{\mathbf{2}}$ \\
\hline $\begin{array}{l}\text { Combined } \\
\text { 'Outer islands' }\end{array}$ & $\mathrm{y}=0.0112 \mathrm{HDI}-0.2695$ & 0.0262 & $\mathrm{y}=-0.4456 \mathrm{FFI}+0.5075$ & 0.042 \\
\hline Sumatra & $y=0.0066 \mathrm{HDI}+0.1363$ & 0.004 & $y=-1.0467 \mathrm{FFI}+0.7261$ & 0.4549 \\
\hline Kalimantan & $y=0.0406 \mathrm{HDI}-1.9986$ & 0.2911 & $y=-1.2302 \mathrm{FFI}+0.8704$ & 0.5397 \\
\hline Nusa Tenggara & $y=0.0205 \mathrm{HDI}-0.7682$ & 0.1499 & $y=-0.0178 \mathrm{FFI}+0.4366$ & $1 E-06$ \\
\hline Java & $\mathrm{y}=-0.0103 \mathrm{HDI}+0.905$ & 0.089 & $\mathrm{y}=-0.0703 \mathrm{FFI}+0.2438$ & 0.0016 \\
\hline
\end{tabular}




\section{District Typologies}

The 'hard' and 'soft' selection processes produce eligible land for $\mathrm{A} / \mathrm{R}$ CDM project activities with the embedded opportunity to meet the objective of sustainable development. At the same time local governments and hosts could anticipate potential project risks for the carbon assets to leak. The terms 'eligible' and 'ineligible' to label each district should be interpreted in association with the potential threatening factors.

The further discussion is based on a data set of 'potentially eligible' areas, which were identified as meeting the requirement of having been deforested before 1990, called 'Kyoto lands', and where at least 500 ha of such lands are available to make a project possible.

District typologies that indicate groupings based on a certain attribute may further be clustered. This way site selection to host A/R CDM may begin. The typology should be further refined or fine-tuned and guided by local considerations. Stakeholder consultation, which was not undertaken for this reporting, should be prioritised.

\section{1 $A / R$ CDM eligible land area by district}

In the next step, the Kyoto lands are split between paddy rice fields (where tree-based production is unlikely to be relevant) and 'eligible Kyoto lands' with other upland uses, where CDM can be explored.

The CDM eligible lands derived from 'hard' selection criteria are shown in Appendix 1. The area in each district may be further adjusted depending on local priorities. For example, some district may well in advance plan to increase its cultivated area as irrigation scheme and market for the commodities had been previously studied. In contrary, some of the districts may reclaim the lost conservation area that may not fall under the rules and modalities of the $\mathrm{A} / \mathrm{R} \mathrm{CDM}$ project activities. In so doing, the fraction of CDM eligible lands, as expressed by the ratio of CDM eligible land area to district area, may be determined as part of local land use planning.

\subsection{Meeting sustainable development objectives}

In addition to the deduction of rice field areas, the argument of excluding areas with high population densities and the more-prosperous communities has direct implications on eligibility for most districts in Java and for a few districts in the outer islands.

The HDI range indicated in the BAPPENAS and UNDP studies was unequally distributed. Based on the most recent SUSENAS data, no indices below 50 or above 80 were found, which suggests that the value of 66 may be used as threshold between low and high HDI. Districts with HDI below 66 are considered as 'not' wealthy, while those with indices above 66 are counted among the wealthy districts. Districts' population densities and HDI are shown in Appendix 2.

Fire risk as a factor to be anticipated is used as a flag for each of the districts to prepare in managing the risks and optimising the opportunity. The list of districts' fire risks is shown in Appendix 3.

The areas in Java, Sumatra, Kalimantan, Nusa Tenggara, Sulawesi, Molluca and Papua that meet these criteria involve $195 \mathrm{M}$ ha in 302 districts with $48 \mathrm{M}$ ha of 'eligible Kyoto lands', $158 \mathrm{M}$ people and a mean HDI of 64.7. The mean of district-level population density is 293 persons $/ \mathrm{km}^{2}$ and the mean FRI is 0.086 .

\subsection{Applying criteria for prioritising districts}

Although all these districts may be able to develop 'valid' project proposals for CDM (and there is no formal reason why they cannot), a priority-setting 
process may include the following criteria:

1) low HDI, reflecting the focus on 'development' in CDM; the mean (64.9) was chosen as threshold;

2) medium population density of between 10 and 100 persons $/ \mathrm{km}^{2}$; at very low densities 'reforestation' is likely to depend on external supply of labour (defying the positive development aspect), while at high densities tree-based land use systems are unlikely to provide sufficient returns to labour, leading to competition for land between tree-based and intensive land use types. We tentatively used a value of 100 persons $/ \mathrm{km}^{2}$, as the most intensive tree-based system we know (rubber agroforest) absorbs 60-70 persons $/ \mathrm{km}^{2}$, and we can allow for a non-rural component of the population at district level (more precise data on 'rural population' are not available at this stage);

3) minimum fraction of district that is Kyoto land and not rice fields; we suggest $15 \%$ as cutoff point, as below this value CDM is unlikely to warrant attention at district scale.

With these three criteria we obtain a priority list of 60 districts, or $20 \%$ of total. This priority list involves $46 \mathrm{M}$ ha $(24 \%$ of total) with $19 \mathrm{M}$ ha of 'Kyoto lands' (40\% of total) and $19.5 \mathrm{M}$ people (12\% of total). The areas have a mean HDI of 62.9 (reflecting the 'pro-poor' prioritisation). The mean of district-level population density is 53 person $/ \mathrm{km}^{2}$ (the larger districts tend to have a lower density) and the mean fire frequency index is 0.135 (60\% higher than for the set as a whole). It seems reasonable to use this 'priority list' (Figure 10; Table 2) as the potential domain for CDM application and to look for districts that 'represent' the three categories of fire frequency index, as well as other characteristics that we found to be associated with the priority list.

\subsection{Clustering of districts based on similarity}

Assessing the degree of similarity of these priority districts becomes the next step of analysis. Grouping of districts based on the degree of similarity is considered useful to ensure that the districts to be selected represent similar characteristics. This procedure will also allow for the estimation of success across those districts in the same group by extrapolation.

First, cluster analysis was applied to all districts in the data set using nine input indicators representing district area, land use, population density, HDI and fire risk (Appendix 5). A subset to the priority districts was then compiled to see the clustering within priority districts.

From the analysis, 15 clusters were obtained, three of which were extracted and suggested as the basis for further selection.

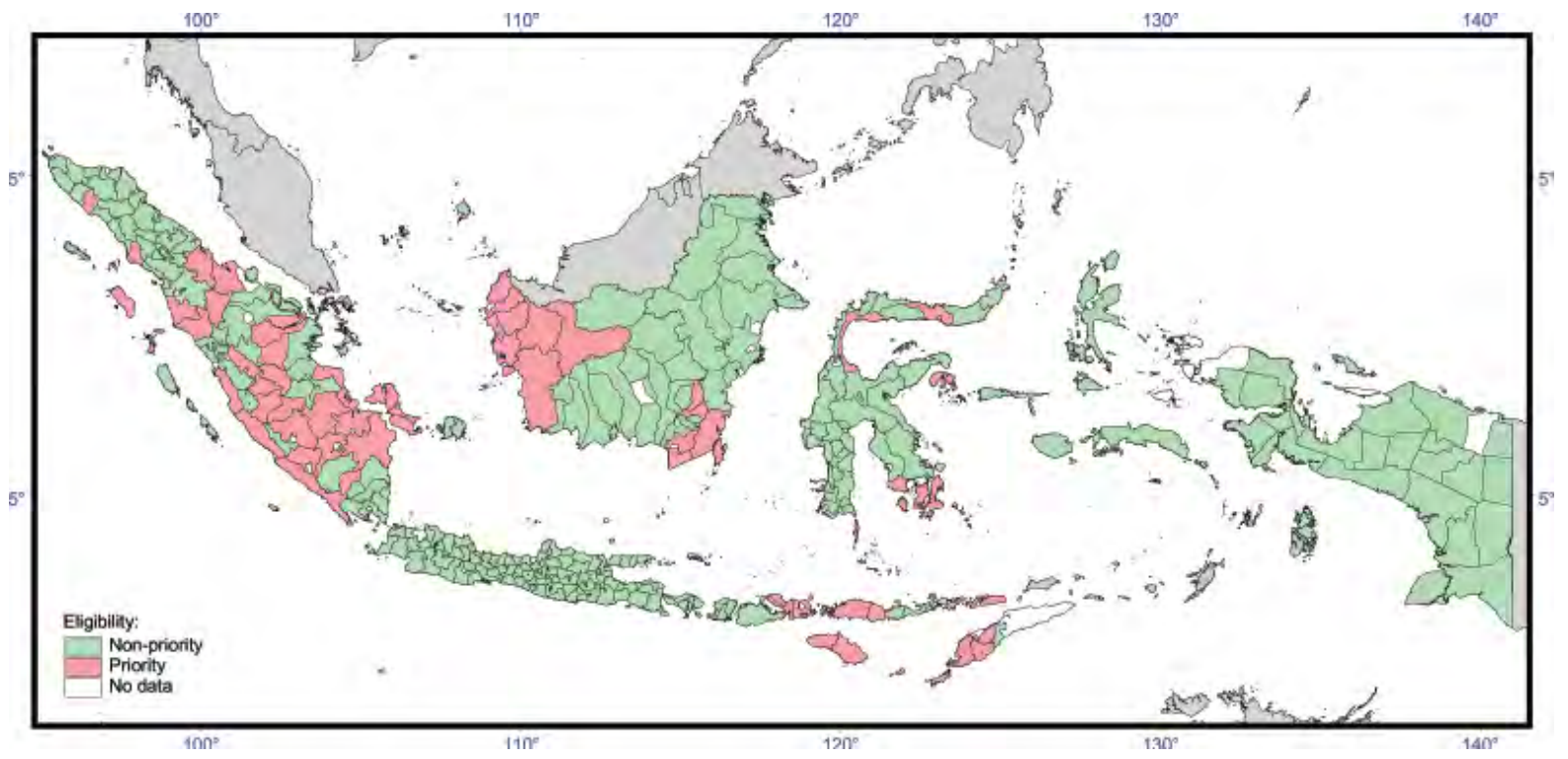

Figure 10. Districts prioritised for CDM based on the criteria: minimum 15\% of eligible lands in the district, population density between 10 and 100 persons $/ \mathrm{km}^{2}$, HDI below 65 
Table 2. Districts that meet the 'priority' criteria of HDI below data set mean, population density between 10 and 100 persons $/ \mathrm{km}^{2}$ and at least $15 \%$ of district eligible

\begin{tabular}{|c|c|c|c|c|c|}
\hline Code & District & Province & HDI 2002 & $\begin{array}{c}\text { Population } \\
\text { Density } \\
\text { (persons/km²) }\end{array}$ & $\begin{array}{l}\text { Potential CDM } \\
\text { Fraction } \\
\end{array}$ \\
\hline \multicolumn{6}{|c|}{ Priority districts with low fire frequency } \\
\hline 1115 & Nagan Raya & Nanggroe Aceh Darussalam & 66 & 39 & 0.305 \\
\hline 1202 & Mandailing Natal & North Sumatra & 64 & 53 & 0.160 \\
\hline 1302 & Pesisir Selatan & West Sumatra & 66 & 64 & 0.207 \\
\hline 1304 & Sawahlunto/Sijunjung & West Sumatra & 62 & 54 & 0.244 \\
\hline 1309 & Pasaman & West Sumatra & 64 & 65 & 0.324 \\
\hline 1701 & Bengkulu Selatan & Bengkulu & 65 & 17 & 0.310 \\
\hline 1801 & Lampung Barat & Lampung & 63 & 72 & 0.202 \\
\hline 5205 & Dompu & West Nusa Tenggara & 58 & 87 & 0.327 \\
\hline 5206 & Bima & West Nusa Tenggara & 59 & 93 & 0.265 \\
\hline 5301 & Sumba Barat & East Nusa Tenggara & 53 & 98 & 0.516 \\
\hline 5302 & Sumba Timur & East Nusa Tenggara & 57 & 29 & 0.573 \\
\hline 5303 & Kupang & East Nusa Tenggara & 57 & 60 & 0.477 \\
\hline 5304 & Timor Tengah Selatan & East Nusa Tenggara & 58 & 99 & 0.512 \\
\hline 5305 & Timor Tengah Utara & East Nusa Tenggara & 60 & 75 & 0.626 \\
\hline 5307 & Alor & East Nusa Tenggara & 57 & 56 & 0.291 \\
\hline 5308 & Lembata & East Nusa Tenggara & 62 & 76 & 0.326 \\
\hline 5312 & Ngada & East Nusa Tenggara & 64 & 79 & 0.411 \\
\hline 5313 & Manggarai & East Nusa Tenggara & 60 & 69 & 0.303 \\
\hline 7201 & Banggai Kepulauan & Central Sulawesi & 61 & 47 & 0.199 \\
\hline 7301 & Selayar & South Sulawesi & 64 & 90 & 0.155 \\
\hline 7402 & Muna & Southeast Sulawesi & 61 & 64 & 0.293 \\
\hline 7502 & Gorontalo & Gorontalo & 65 & 70 & 0.251 \\
\hline \multicolumn{6}{|c|}{ Priority districts with medium fire frequency } \\
\hline 1102 & Aceh Singkil & Nanggroe Aceh Darussalam & 62 & 47 & 0.215 \\
\hline 1201 & Labuhan Batu & North Sumatra & 62 & 32 & 0.571 \\
\hline 1402 & Indragiri Hulu & Riau & 66 & 34 & 0.337 \\
\hline 1404 & Pelalawan & Riau & 66 & 15 & 0.237 \\
\hline 1502 & Merangin & Jambi & 66 & 37 & 0.378 \\
\hline 1503 & Sarolangun & Jambi & 65 & 27 & 0.454 \\
\hline 1506 & Tanjung Jabung Timur & Jambi & 65 & 39 & 0.329 \\
\hline 1508 & Tebo & Jambi & 65 & 34 & 0.425 \\
\hline 1509 & Bungo & Jambi & 64 & 48 & 0.522 \\
\hline 1604 & Lahat & South Sumatra & 65 & 75 & 0.605 \\
\hline 1605 & Musi Rawas & South Sumatra & 62 & 36 & 0.550 \\
\hline 1703 & Bengkulu Utara & Bengkulu & 64 & 31 & 0.393 \\
\hline 6101 & Sambas & West Kalimantan & 59 & 79 & 0.344 \\
\hline 6102 & Bengkayang & West Kalimantan & 63 & 35 & 0.458 \\
\hline 6104 & Pontianak & West Kalimantan & 64 & 63 & 0.164 \\
\hline 6302 & Kota Baru & South Kalimantan & 65 & 18 & 0.247 \\
\hline 6309 & Tabalong & South Kalimantan & 63 & 50 & 0.427 \\
\hline 7401 & Buton & Southeast Sulawesi & 63 & 64 & 0.259 \\
\hline \multicolumn{6}{|c|}{ Priority districts with high fire frequency } \\
\hline 1407 & Rokan Hulu & Riau & 64 & 40 & 0.522 \\
\hline 1409 & Rokan Hilir & Riau & 66 & 41 & 0.444 \\
\hline 1602 & Ogan Komering Ilir & South Sumatra & 63 & 48 & 0.534 \\
\hline 1603 & Muara Enim & South Sumatra & 64 & 73 & 0.845 \\
\hline 1606 & Musi Banyu Asin & South Sumatra & 65 & 28 & 0.416 \\
\hline 1607 & Banyu Asin & South Sumatra & 65 & 55 & 0.569 \\
\hline 1807 & Way Kanan & Lampung & 65 & 90 & 0.754 \\
\hline 1901 & Bangka & Kepulauan Bangka Belitung & 65 & 69 & 0.667 \\
\hline
\end{tabular}




\begin{tabular}{lllccc}
\hline Code & \multicolumn{1}{c}{ District } & \multicolumn{1}{c}{ Province } & HDI 2002 & $\begin{array}{c}\text { Population } \\
\text { Density } \\
\text { (persons } / \mathbf{k m}^{2} \text { ) }\end{array}$ & $\begin{array}{c}\text { Potential CDM } \\
\text { Fraction }\end{array}$ \\
\hline 1903 & Bangka Barat & Kepulauan Bangka Belitung & 65 & 45 & 0.689 \\
\hline 1904 & Bangka Tengah & Kepulauan Bangka Belitung & 65 & 60 & 0.629 \\
\hline 1905 & Bangka Selatan & Kepulauan Bangka Belitung & 65 & 37 & 0.607 \\
\hline 6103 & Landak & West Kalimantan & 62 & 35 & 0.511 \\
\hline 6105 & Sanggau & West Kalimantan & 62 & 28 & 0.651 \\
\hline 6106 & Ketapang & West Kalimantan & 64 & 13 & 0.283 \\
\hline 6107 & Sintang & West Kalimantan & 62 & 15 & 0.462 \\
\hline 6301 & Tanah Laut & South Kalimantan & 66 & 64 & 0.461 \\
\hline 6303 & Banjar & South Kalimantan & 64 & 34 & 0.328 \\
\hline 6308 & Hulu Sungai Utara & South Kalimantan & 62 & 70 & 0.380 \\
\hline
\end{tabular}

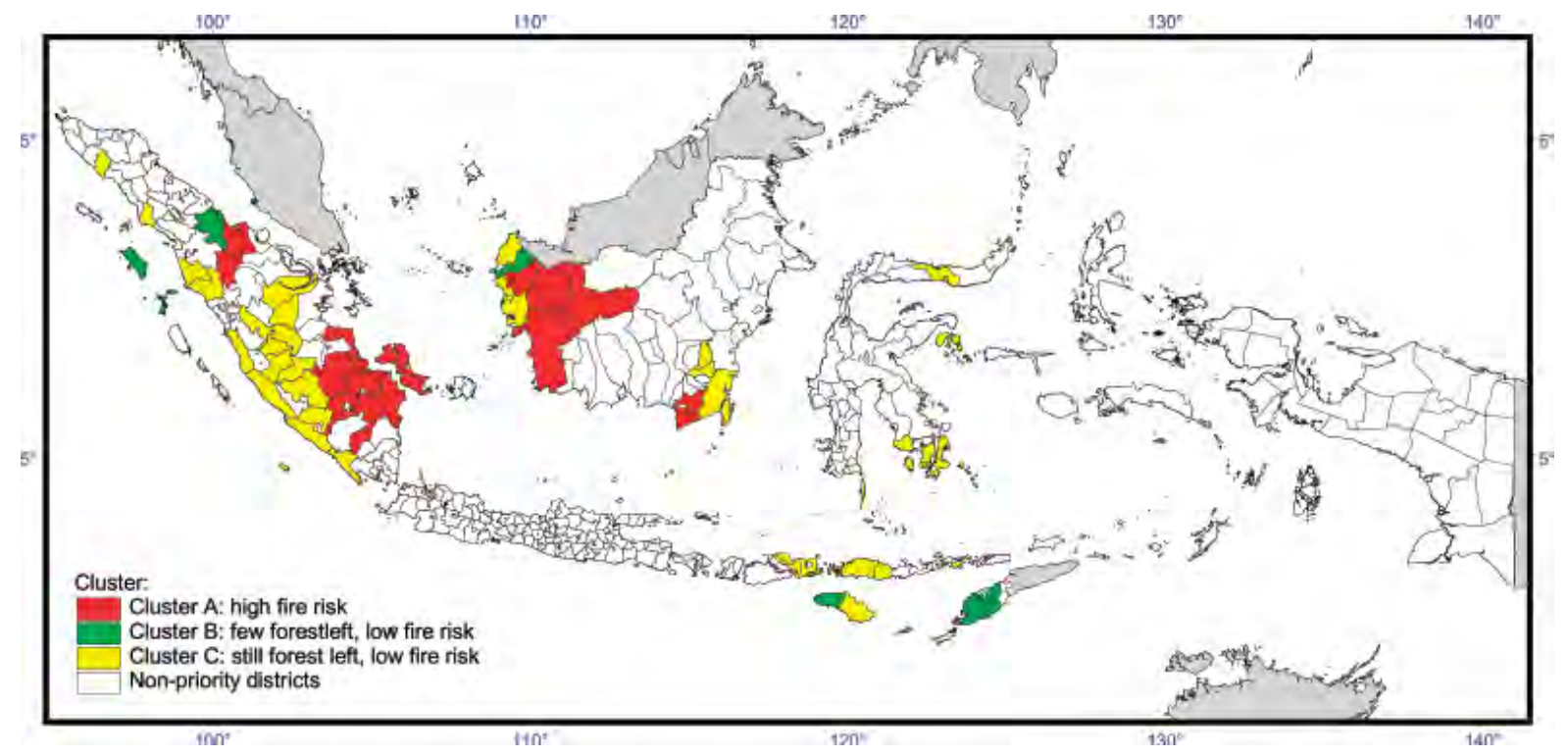

Figure 11. Three clusters suggested representing districts with degrees of similarity

Cluster A: Characterised by high fire risk, the districts are located mostly in the low peneplain areas of eastern Sumatra and in West Kalimantan. Nineteen of 32 districts are on the priority list. For CDM projects proposed in these districts, fire risk should be taken into consideration.

Cluster B: Characterised by low to medium fire risk, the districts are located mostly in Nusa Tenggara. All nine districts are on the priority list.

Cluster C: Characterised by low to medium fire risk, the districts are located mostly at the western mountain range of Bukit Barisan in Sumatra. Fourteen of the 67 districts are on the priority list.
The three clusters based on the similarity in terms of fire risk and terrain can be seen in Figure 11.

Papua is not included in the clusters with fire risk as an attribute, but clusters based on the area or coverage of, for example, conservation area may serve the purpose for this particular region. Likewise, Java is not included, but if the clustering were based on population density, it might be included. As far as A/R CDM project activities are concerned clusters should be based on practical aspect rather than conceptual. 


\section{Further Considerations}

Obviously, other criteria will have to be added to reflect the level of preparedness and interest of local community and district government, as well as the actual land uses on 'Kyoto eligible' lands.

The current analysis at district (kabupaten) level was based on coarse data useful for getting the idea in the broad context (national level). More-detailed analyses with finer data sets, for example on the subdistrict (kecamatan) level, are needed, however, for better identification of land parcels eligible for CDM projects, biophysical as well as socio-economic conditions to be considered and the various risks to be anticipated.
Once detailed analyses are done and eligible land parcels are identified, economic values of various land use options are needed. Some Kyoto eligible lands with higher existing economic value may need to be excluded from prospective CDM lands.

Like other tree-planting activities, CDM projects should benefit local farmers. Thorough socioeconomic studies on the local populations should therefore be done to evaluate whether the project meets the umbrella vision of poverty alleviation. 


\section{References}

BPS, BAPPENAS and UNDP. 2004. National Human Development Report 2004. The Economics of Democracy: Financing Human Development in Indonesia. Jakarta, Indonesia: UNDP. 207p

Hadi, DP and van Noordwijk, M. 2006. Agroecosystems, their population densities and land cover in Indonesia in the context of uplandlowland relationships. In: van Noordwijk $\mathrm{M}$ and O'Connor T,eds. Highlights of ongoing research of the world agroforestry centre in Indonesia. Bogor, Indonesia. World Agroforestry Centre ICRAF, SEA Regional Office.

Loveland, T. et al. 1998. Global Land Cover Characterization. Sioux Falls, SD: USGS EROS Data Center
Iremonger, S., Ravilious, C. And Quinton, T. (eds.), 1997. A global overview of forest conservation. CD-ROM. WCMC and CIFOR, Cambridge, U.K.

Ministry of Forestry. 1999. Forestry Statistics of Indonesia 1997/1998. Agency for Forest Inventory and Land Use Planning. Jakarta.

Regional Physical Planning Programme for Transmigration (RePPProT). 1990. The Land Resources of Indonesia: a national overview. London: Land Resources Department, Natural Resources Institute. 282 p.

Stibig, H-J., Beuchle, R. and Janvier, P. 2002. Forest cover map of Insular Southeast Asia at 1:5500000. TREES Publications Series D: No. 3, EUR 20129 EN, European Commission, Luxemburg. 


\section{Appendices}

Appendix 1. CDM eligible land by district

\begin{tabular}{|c|c|c|c|c|c|c|}
\hline $\begin{array}{l}\text { District } \\
\text { Code }\end{array}$ & Province & District & $\begin{array}{l}\text { District area } \\
\text { (ha) }\end{array}$ & $\begin{array}{l}\text { "Kyotoland" } \\
\text { (ha) }\end{array}$ & $\begin{array}{l}\text { Ricefield } \\
\text { (ha) }\end{array}$ & $\begin{array}{l}\text { Eligible land } \\
\text { (ha)* }\end{array}$ \\
\hline 1101 & $\begin{array}{l}\text { Nanggroe Aceh } \\
\text { Darussalam }\end{array}$ & Simeulue & 207136.80 & 29069.76 & 20942 & 8127.76 \\
\hline 1102 & $\begin{array}{l}\text { Nanggroe Aceh } \\
\text { Darussalam }\end{array}$ & Aceh Singkil & 364225.11 & 109715.86 & 31556 & 78159.86 \\
\hline 1103 & $\begin{array}{l}\text { Nanggroe Aceh } \\
\text { Darussalam }\end{array}$ & Aceh Selatan & 398194.90 & 34025.36 & 28696 & 5329.36 \\
\hline 1104 & $\begin{array}{l}\text { Nanggroe Aceh } \\
\text { Darussalam }\end{array}$ & Aceh Tenggara & 483685.58 & 33762.60 & 27927 & 5835.60 \\
\hline 1105 & $\begin{array}{l}\text { Nanggroe Aceh } \\
\text { Darussalam }\end{array}$ & Aceh Timur & 592734.81 & 262790.91 & 67714 & 195076.91 \\
\hline 1106 & $\begin{array}{l}\text { Nanggroe Aceh } \\
\text { Darussalam }\end{array}$ & Aceh Tengah & 728881.53 & 112606.78 & 12828 & 99778.78 \\
\hline 1107 & $\begin{array}{l}\text { Nanggroe Aceh } \\
\text { Darussalam }\end{array}$ & Aceh Barat & 353416.14 & 150350.02 & 101356 & 48994.02 \\
\hline 1108 & $\begin{array}{l}\text { Nanggroe Aceh } \\
\text { Darussalam }\end{array}$ & Aceh Besar & 322745.27 & 147099.57 & 37336 & 109763.57 \\
\hline 1109 & $\begin{array}{l}\text { Nanggroe Aceh } \\
\text { Darussalam }\end{array}$ & Pidie & 471800.71 & 142087.38 & 54968 & 87119.38 \\
\hline 1110 & $\begin{array}{l}\text { Nanggroe Aceh } \\
\text { Darussalam }\end{array}$ & Bireuen & 190778.76 & 84648.60 & 18450 & 66198.60 \\
\hline 1111 & $\begin{array}{l}\text { Nanggroe Aceh } \\
\text { Darussalam }\end{array}$ & Aceh Utara & 269572.63 & 181450.34 & 48179 & 133271.34 \\
\hline 1112 & $\begin{array}{l}\text { Nanggroe Aceh } \\
\text { Darussalam }\end{array}$ & Aceh Barat Daya & 255660.67 & 30960.12 & n.a. & 30960.12 \\
\hline 1113 & $\begin{array}{l}\text { Nanggroe Aceh } \\
\text { Darussalam }\end{array}$ & Gayo Lues & 619822.88 & 56431.23 & n.a. & 56431.23 \\
\hline 1114 & $\begin{array}{l}\text { Nanggroe Aceh } \\
\text { Darussalam }\end{array}$ & Aceh Tamiang & 245743.08 & 131339.32 & n.a. & 131339.32 \\
\hline 1115 & $\begin{array}{l}\text { Nanggroe Aceh } \\
\text { Darussalam }\end{array}$ & Nagan Raya & 386546.21 & 117984.18 & n.a. & 117984.18 \\
\hline 1116 & $\begin{array}{l}\text { Nanggroe Aceh } \\
\text { Darussalam }\end{array}$ & Aceh Jaya & 431549.51 & 78604.90 & n.a. & 78604.90 \\
\hline 1201 & North Sumatra & Labuhan Batu & 1640953.25 & 1003023.15 & 65395 & 937628.15 \\
\hline 1202 & North Sumatra & Mandailing Natal & 696569.90 & 152302.31 & 40601 & 111701.31 \\
\hline 1203 & North Sumatra & Tapanuli Selatan & 1307446.14 & 498704.93 & 67654 & 431050.93 \\
\hline 1204 & North Sumatra & Tapanuli Tengah & 264323.81 & 91729.16 & 33162 & 58567.16 \\
\hline 1205 & North Sumatra & Tapanuli Utara & 643672.70 & 145599.37 & 64740 & 80859.37 \\
\hline 1206 & North Sumatra & Toba Samosir & 408939.22 & 97265.30 & 24974 & 72291.30 \\
\hline 1208 & North Sumatra & Asahan & 510575.08 & 404103.92 & 47225 & 356878.92 \\
\hline 1209 & North Sumatra & Simalungun & 491690.76 & 376770.86 & 47031 & 329739.86 \\
\hline 1210 & North Sumatra & Dairi & 490829.72 & 121605.02 & 13675 & 107930.02 \\
\hline 1211 & North Sumatra & Karo & 241020.74 & 113010.74 & 15096 & 97914.74 \\
\hline 1212 & North Sumatra & Deli Serdang & 505664.32 & 439294.77 & 99866 & 339428.77 \\
\hline 1213 & North Sumatra & Langkat & 690264.40 & 374762.14 & 61868 & 312894.14 \\
\hline 1301 & West Sumatra & Kepulauan Mentawai & 653894.71 & 13723.73 & 4088 & 9635.73 \\
\hline
\end{tabular}




\begin{tabular}{|c|c|c|c|c|c|c|}
\hline $\begin{array}{l}\text { District } \\
\text { Code }\end{array}$ & Province & District & $\begin{array}{l}\text { District area } \\
\text { (ha) }\end{array}$ & $\begin{array}{l}\text { "Kyotoland" } \\
\text { (ha) }\end{array}$ & $\begin{array}{l}\text { Ricefield } \\
\text { (ha) }\end{array}$ & $\begin{array}{l}\text { Eligible land } \\
\text { (ha)* }\end{array}$ \\
\hline 1302 & West Sumatra & Pesisir Selatan & 646016.65 & 174888.63 & 40884 & 134004.63 \\
\hline 1303 & West Sumatra & Solok & 737173.41 & 114213.60 & 39725 & 74488.60 \\
\hline 1304 & West Sumatra & Sawahlunto/Sijunjung & 628094.15 & 182853.42 & 29530 & 153323.42 \\
\hline 1305 & West Sumatra & Tanah Datar & 148490.41 & 51382.58 & 30968 & 20414.58 \\
\hline 1306 & West Sumatra & Padang Pariaman & 172836.37 & 77980.49 & 28455 & 49525.49 \\
\hline 1307 & West Sumatra & Agam & 246481.10 & 114489.72 & 38129 & 76360.72 \\
\hline 1308 & West Sumatra & Lima Puluh Koto & 311903.76 & 96237.57 & 38709 & 57528.57 \\
\hline 1309 & West Sumatra & Pasaman & 848442.67 & 324049.79 & 48776 & 275273.79 \\
\hline 1401 & Riau & Kuantan Singingi & 551732.96 & 241426.18 & 25524 & 215902.18 \\
\hline 1402 & Riau & Indragiri Hulu & 838907.40 & 319783.40 & 37075 & 282708.40 \\
\hline 1403 & Riau & Indragiri Hilir & 1307633.56 & 690502.41 & 93269 & 597233.41 \\
\hline 1404 & Riau & Pelalawan & 1401268.48 & 371215.63 & 39750 & 331465.63 \\
\hline 1405 & Riau & Siak & 863634.29 & 370751.45 & 16127 & 354624.45 \\
\hline 1406 & Riau & Kampar & 1137858.96 & 654151.21 & 49750 & 604401.21 \\
\hline 1407 & Riau & Rokan Hulu & 822439.39 & 449723.53 & 20287 & 429436.53 \\
\hline 1408 & Riau & Bengkalis & 1246465.03 & 403984.33 & 66703 & 337281.33 \\
\hline 1409 & Riau & Rokan Hilir & 1023553.67 & 497485.83 & 42980 & 454505.83 \\
\hline 1410 & Riau & Kepulauan Riau & 429534.55 & 77117.37 & 2897 & 74220.37 \\
\hline 1411 & Riau & Karimun & 97662.68 & 43075.74 & 0 & 43075.74 \\
\hline 1412 & Riau & Natuna & 283578.64 & 33779.53 & 2188 & 31591.53 \\
\hline 1501 & Jambi & Kerinci & 400131.71 & 78969.52 & 28596 & 50373.52 \\
\hline 1502 & Jambi & Merangin & 738899.17 & 290693.94 & 11727 & 278966.94 \\
\hline 1503 & Jambi & Sarolangun & 710660.03 & 334914.00 & 12185 & 322729.00 \\
\hline 1504 & Jambi & Batanghari & 615202.00 & 296661.28 & 32090 & 264571.28 \\
\hline 1505 & Jambi & Muara Jambi & 499349.49 & 259651.87 & 29124 & 230527.87 \\
\hline 1506 & Jambi & Tanjung Jabung Timur & 513253.38 & 267312.07 & 98486 & 168826.07 \\
\hline 1507 & Jambi & Tanjung Jabung Barat & 576664.70 & 234502.92 & 30636 & 203866.92 \\
\hline 1508 & Jambi & Tebo & 665371.30 & 299244.68 & 16407 & 282837.68 \\
\hline 1509 & Jambi & Bungo & 494431.13 & 278512.21 & 20534 & 257978.21 \\
\hline 1601 & South Sumatra & Ogan Komering Ulu & 1086604.10 & 774061.74 & 119613 & 654448.74 \\
\hline 1602 & South Sumatra & Ogan Komering Ilir & 2048356.30 & 1477744.47 & 383227 & 1094517.47 \\
\hline 1603 & South Sumatra & Muara Enim & 829422.74 & 730001.08 & 29463 & 700538.08 \\
\hline 1604 & South Sumatra & Lahat & 705651.78 & 471291.76 & 44244 & 427047.76 \\
\hline 1605 & South Sumatra & Musi Rawas & 1277002.45 & 762491.62 & 60229 & 702262.62 \\
\hline 1606 & South Sumatra & Musi Banyu Asin & 1585607.76 & 1075199.71 & 415588 & 659611.71 \\
\hline 1607 & South Sumatra & Banyu Asin & 1251936.69 & 719974.07 & 7077 & 712897.07 \\
\hline 1701 & Bengkulu & Bengkulu Selatan & 768084.06 & 304672.95 & 66549 & 238123.95 \\
\hline 1702 & Bengkulu & Rejang Lebong & 408527.18 & 161289.83 & 25078 & 136211.83 \\
\hline 1703 & Bengkulu & Bengkulu Utara & 1041263.40 & 464970.45 & 55726 & 409244.45 \\
\hline 1801 & Lampung & Lampung Barat & 517041.45 & 136177.70 & 31603 & 104574.70 \\
\hline 1802 & Lampung & Tanggamus & 382668.92 & 163250.95 & 31659 & 131591.95 \\
\hline 1803 & Lampung & Lampung Selatan & 455843.85 & 260180.71 & 64393 & 195787.71 \\
\hline 1804 & Lampung & Lampung Timur & 291058.26 & 242640.74 & 60930 & 181710.74 \\
\hline 1805 & Lampung & Lampung Tengah & 456640.39 & 418957.42 & 58753 & 360204.42 \\
\hline 1806 & Lampung & Lampung Utara & 243742.53 & 215509.71 & 20376 & 195133.71 \\
\hline 1807 & Lampung & Way Kanan & 410099.67 & 335305.03 & 26134 & 309171.03 \\
\hline 1808 & Lampung & Tulang Bawang & 703463.38 & 631084.28 & 88247 & 542837.28 \\
\hline 1901 & $\begin{array}{l}\text { Kepulauan Bangka } \\
\text { - Belitung }\end{array}$ & Bangka & 325113.57 & 230213.41 & 13244 & 216969.41 \\
\hline 1902 & $\begin{array}{l}\text { Kepulauan Bangka } \\
\text { - Belitung }\end{array}$ & Belitung & 237577.60 & 118065.90 & 625 & 117440.90 \\
\hline 1903 & $\begin{array}{l}\text { Kepulauan Bangka } \\
\text { - Belitung }\end{array}$ & Bangka Barat & 301859.58 & 208087.65 & n.a. & 208087.65 \\
\hline 1904 & $\begin{array}{l}\text { Kepulauan Bangka } \\
\text { - Belitung }\end{array}$ & Bangka Tengah & 206605.34 & 129944.56 & n.a. & 129944.56 \\
\hline
\end{tabular}




\begin{tabular}{|c|c|c|c|c|c|c|}
\hline $\begin{array}{c}\text { District } \\
\text { Code }\end{array}$ & Province & District & $\begin{array}{l}\text { District area } \\
\text { (ha) }\end{array}$ & $\begin{array}{l}\text { "Kyotoland" } \\
\text { (ha) }\end{array}$ & $\begin{array}{c}\text { Ricefield } \\
\text { (ha) }\end{array}$ & $\begin{array}{c}\text { Eligible land } \\
\text { (ha)* }\end{array}$ \\
\hline 1905 & $\begin{array}{l}\text { Kepulauan Bangka } \\
\text { - Belitung }\end{array}$ & Bangka Selatan & 380391.77 & 230759.40 & n.a. & 230759.40 \\
\hline 1906 & $\begin{array}{l}\text { Kepulauan Bangka } \\
\text { - Belitung }\end{array}$ & Belitung Timur & 206839.20 & 122746.83 & n.a. & 122746.83 \\
\hline 3201 & West Java & Bogor & 306501.21 & 226956.89 & 56385 & 170571.89 \\
\hline 3202 & West Java & Sukabumi & 428466.81 & 317192.60 & 66997 & 250195.60 \\
\hline 3203 & West Java & Cianjur & 374097.10 & 259704.90 & 77291 & 182413.90 \\
\hline 3204 & West Java & Bandung & 314423.57 & 188133.48 & 62152 & 125981.48 \\
\hline 3205 & West Java & Garut & 315697.79 & 178637.86 & 54145 & 124492.86 \\
\hline 3206 & West Java & Tasikmalaya & 281499.30 & 202808.32 & 56619 & 146189.32 \\
\hline 3207 & West Java & Ciamis & 277999.65 & 213459.01 & 66461 & 146998.01 \\
\hline 3208 & West Java & Kuningan & 124603.30 & 92661.12 & 98548 & -5886.88 \\
\hline 3209 & West Java & Cirebon & 107320.96 & 95264.11 & 57752 & 37512.11 \\
\hline 3210 & West Java & Majalengka & 134191.84 & 120008.39 & 52937 & 67071.39 \\
\hline 3211 & West Java & Sumedang & 161175.81 & 125293.72 & 35403 & 89890.72 \\
\hline 3212 & West Java & Indramayu & 209791.81 & 181428.92 & 108175 & 73253.92 \\
\hline 3213 & West Java & Subang & 221540.39 & 185266.45 & 86058 & 99208.45 \\
\hline 3214 & West Java & Purwakarta & 97552.26 & 70347.68 & 18931 & 51416.68 \\
\hline 3215 & West Java & Karawang & 198463.08 & 155281.71 & 88526 & 66755.71 \\
\hline 3216 & West Java & Bekasi & 129682.83 & 108216.26 & 59101 & 49115.26 \\
\hline 3301 & Central Java & Cilacap & 230901.89 & 161978.94 & 64486 & 97492.94 \\
\hline 3302 & Central Java & Banyumas & 142813.07 & 114294.10 & 34220 & 80074.10 \\
\hline 3303 & Central Java & Purbalingga & 82654.08 & 56430.91 & 21038 & 35392.91 \\
\hline 3304 & Central Java & Banjarnegara & 116285.67 & 80111.14 & 15682 & 64429.14 \\
\hline 3305 & Central Java & Kebumen & 134370.93 & 114862.44 & 42362 & 72500.44 \\
\hline 3306 & Central Java & Purworejo & 109490.47 & 91536.67 & 30306 & 61230.67 \\
\hline 3307 & Central Java & Wonosobo & 100524.85 & 58981.17 & 18565 & 40416.17 \\
\hline 3308 & Central Java & Magelang & 114516.40 & 84988.45 & 38376 & 46612.45 \\
\hline 3309 & Central Java & Boyolali & 110684.38 & 99863.85 & 23263 & 76600.85 \\
\hline 3310 & Central Java & Klaten & 67329.36 & 65218.62 & 34244 & 30974.62 \\
\hline 3311 & Central Java & Sukoharjo & 51552.72 & 51223.71 & 21176 & 30047.71 \\
\hline 3312 & Central Java & Wonogiri & 192492.99 & 178436.12 & 31434 & 147002.12 \\
\hline 3313 & Central Java & Karanganyar & 81928.14 & 70878.84 & 22856 & 48022.84 \\
\hline 3314 & Central Java & Sragen & 98172.85 & 93337.30 & 39966 & 53371.30 \\
\hline 3315 & Central Java & Grobogan/Purwodadi & 199907.44 & 196897.13 & 61843 & 135054.13 \\
\hline 3316 & Central Java & Blora & 196019.25 & 195147.10 & 45727 & 149420.10 \\
\hline 3317 & Central Java & Rembang & 106793.03 & 100662.95 & 29464 & 71198.95 \\
\hline 3318 & Central Java & Pati & 159835.08 & 144567.00 & 57677 & 86890.00 \\
\hline 3319 & Central Java & Kudus & 42716.52 & 39796.63 & 21720 & 18076.63 \\
\hline 3320 & Central Java & Jepara & 107735.78 & 74013.35 & 26135 & 47878.35 \\
\hline 3321 & Central Java & Demak & 98940.80 & 88937.79 & 51373 & 37564.79 \\
\hline 3322 & Central Java & Semarang & 102834.72 & 83663.02 & 25795 & 57868.02 \\
\hline 3323 & Central Java & Temanggung & 89169.68 & 76920.97 & 27847 & 49073.97 \\
\hline 3324 & Central Java & Kendal & 102536.39 & 78556.38 & 27268 & 51288.38 \\
\hline 3325 & Central Java & Batang & 75002.98 & 58548.62 & 22709 & 35839.62 \\
\hline 3326 & Central Java & Pekalongan & 98479.18 & 51720.51 & 26147 & 25573.51 \\
\hline 3327 & Central Java & Pemalang & 113752.32 & 90251.70 & 38939 & 51312.70 \\
\hline 3328 & Central Java & Tegal & 100231.03 & 86735.23 & 194619 & -107883.77 \\
\hline 3329 & Central Java & Brebes & 175972.27 & 128602.25 & 143905 & -15302.75 \\
\hline 3401 & DI Yogyakarta & Kulon Progo & 61078.55 & 51884.76 & 11097 & 40787.76 \\
\hline 3402 & DI Yogyakarta & Bantul & 49215.51 & 44320.14 & 16613 & 27707.14 \\
\hline 3403 & DI Yogyakarta & Gunung Kidul & 147688.46 & 143789.05 & 10131 & 133658.05 \\
\hline 3404 & DI Yogyakarta & Sleman & 57489.25 & 52063.17 & 23648 & 28415.17 \\
\hline 3501 & East Java & Pacitan & 142654.39 & 134248.30 & 13337 & 120911.30 \\
\hline
\end{tabular}




\begin{tabular}{|c|c|c|c|c|c|c|}
\hline $\begin{array}{c}\text { District } \\
\text { Code } \\
\end{array}$ & Province & District & $\begin{array}{c}\text { District area } \\
\text { (ha) }\end{array}$ & $\begin{array}{c}\text { "Kyotoland" } \\
\text { (ha) }\end{array}$ & $\begin{array}{c}\text { Ricefield } \\
\text { (ha) }\end{array}$ & $\begin{array}{c}\text { Eligible land } \\
\text { (ha)* }\end{array}$ \\
\hline 3502 & East Java & Ponorogo & 145047.39 & 121254.17 & 34837 & 86417.17 \\
\hline 3503 & East Java & Trenggalek & 125737.32 & 100594.25 & 11985 & 88609.25 \\
\hline 3504 & East Java & Tulungagung & 116385.54 & 95001.24 & 23183 & 71818.24 \\
\hline 3505 & East Java & Blitar & 174708.65 & 146812.51 & 31662 & 115150.51 \\
\hline 3506 & East Java & Kediri & 155319.75 & 137385.78 & 50992 & 86393.78 \\
\hline 3507 & East Java & Malang & 352940.15 & 240555.21 & 51438 & 189117.21 \\
\hline 3508 & East Java & Lumajang & 180980.53 & 107094.42 & 37457 & 69637.42 \\
\hline 3509 & East Java & Jember & 335953.15 & 200018.87 & 84611 & 115407.87 \\
\hline 3510 & East Java & Banyuwangi & 354447.18 & 168858.90 & 69387 & 99471.90 \\
\hline 3511 & East Java & Bondowoso & 155520.77 & 101432.54 & 30448 & 70984.54 \\
\hline 3512 & East Java & Situbondo & 162309.65 & 102945.61 & 31832 & 71113.61 \\
\hline 3513 & East Java & Probolinggo & 172799.82 & 112808.23 & 526760 & -413951.77 \\
\hline 3514 & East Java & Pasuruan & 149398.52 & 115919.53 & 40416 & 75503.53 \\
\hline 3515 & East Java & Sidoarjo & 68652.83 & 50569.87 & 25955 & 24614.87 \\
\hline 3516 & East Java & Mojokerto & 100126.04 & 78795.34 & 36741 & 42054.34 \\
\hline 3517 & East Java & Jombang & 109693.59 & 103039.03 & 48636 & 54403.03 \\
\hline 3518 & East Java & Nganjuk & 128918.68 & 117318.02 & 42993 & 74325.02 \\
\hline 3519 & East Java & Madiun & 111557.63 & 103259.97 & 32291 & 70968.97 \\
\hline 3520 & East Java & Magetan & 72495.64 & 61996.88 & 29273 & 32723.88 \\
\hline 3521 & East Java & Ngawi & 140951.81 & 135764.79 & 50666 & 85098.79 \\
\hline 3522 & East Java & Bojonegoro & 236190.62 & 230630.02 & 174270 & 56360.02 \\
\hline 3523 & East Java & Tuban & 199037.73 & 188925.78 & 64247 & 124678.78 \\
\hline 3524 & East Java & Lamongan & 177649.76 & 166822.93 & 86239 & 80583.93 \\
\hline 3525 & East Java & Gresik & 122664.93 & 86631.45 & 36806 & 49825.45 \\
\hline 3526 & East Java & Bangkalan & 131131.14 & 123522.29 & 30552 & 92970.29 \\
\hline 3527 & East Java & Sampang & 123754.20 & 115389.77 & 22383 & 93006.77 \\
\hline 3528 & East Java & Pamekasan & 80533.92 & 77109.73 & 16918 & 60191.73 \\
\hline 3529 & East Java & Sumenep & 215965.81 & 122766.19 & 23274 & 99492.19 \\
\hline 3601 & Banten & Pandeglang & 289958.52 & 178936.66 & 61020 & 117916.66 \\
\hline 3602 & Banten & Lebak & 334960.96 & 249337.44 & 45834 & 203503.44 \\
\hline 3603 & Banten & Tangerang & 119173.30 & 104462.74 & 43853 & 60609.74 \\
\hline 3604 & Banten & Serang & 183015.16 & 145380.11 & 63006 & 82374.11 \\
\hline 5101 & Bali & Jembrana & 85823.87 & 29101.92 & 7953 & 21148.92 \\
\hline 5102 & Bali & Tabanan & 86909.80 & 44974.10 & 23112 & 21862.10 \\
\hline 5103 & Bali & Badung & 39293.99 & 30346.52 & 11301 & 19045.52 \\
\hline 5104 & Bali & Gianyar & 36477.31 & 23075.86 & 14990 & 8085.86 \\
\hline 5105 & Bali & Klungkung & 30972.19 & 23843.82 & 4108 & 19735.82 \\
\hline 5106 & Bali & Bangli & 52583.45 & 23960.80 & 3078 & 20882.80 \\
\hline 5107 & Bali & Karangasem & 86134.73 & 43740.85 & 7126 & 36614.85 \\
\hline 5108 & Bali & Buleleng & 133563.10 & 65006.30 & 11601 & 53405.30 \\
\hline 5201 & West Nusa Tenggara & Lombok Barat & 172380.29 & 84514.10 & 147794 & -63279.91 \\
\hline 5202 & West Nusa Tenggara & Lombok Tengah & 126292.85 & 94727.08 & 52917 & 41810.08 \\
\hline 5203 & West Nusa Tenggara & LombokTimur & 150385.62 & 81817.21 & 48508 & 33309.21 \\
\hline 5204 & West Nusa Tenggara & Sumbawa & 837565.77 & 178293.35 & 55685 & 122608.35 \\
\hline 5205 & West Nusa Tenggara & Dompu & 218591.72 & 89171.11 & 17655 & 71516.11 \\
\hline 5206 & West Nusa Tenggara & Bima & 431425.32 & 146682.15 & 32296 & 114386.15 \\
\hline 5301 & East Nusa Tenggara & Sumba Barat & 392908.24 & 229069.42 & 26400 & 202669.42 \\
\hline 5302 & East Nusa Tenggara & Sumba Timur & 680117.12 & 413891.05 & 24179 & 389712.05 \\
\hline 5303 & East Nusa Tenggara & Kupang & 551793.53 & 283038.77 & 19775 & 263263.77 \\
\hline 5304 & East Nusa Tenggara & Timor Tengah Selatan & 401686.90 & 213095.22 & 7276 & 205819.22 \\
\hline 5305 & East Nusa Tenggara & Timor Tengah Utara & 268107.32 & 181299.53 & 13554 & 167745.53 \\
\hline 5306 & East Nusa Tenggara & Belu & 226307.06 & 121012.64 & 11834 & 109178.64 \\
\hline 5307 & East Nusa Tenggara & Alor & 296432.37 & 89877.46 & 3559 & 86318.46 \\
\hline 5308 & East Nusa Tenggara & Lembata & 127451.08 & 41669.44 & 65 & 41604.44 \\
\hline
\end{tabular}




\begin{tabular}{|c|c|c|c|c|c|c|}
\hline $\begin{array}{l}\text { District } \\
\text { Code }\end{array}$ & Province & District & $\begin{array}{l}\text { District area } \\
\text { (ha) }\end{array}$ & $\begin{array}{l}\text { "Kyotoland" } \\
\text { (ha) }\end{array}$ & $\begin{array}{c}\text { Ricefield } \\
\text { (ha) }\end{array}$ & $\begin{array}{c}\text { Eligible land } \\
\text { (ha)* }\end{array}$ \\
\hline 5309 & East Nusa Tenggara & Flores Timur & 178248.57 & 53615.53 & 716 & 52899.53 \\
\hline 5310 & East Nusa Tenggara & Sikka & 179408.99 & 78798.66 & 4248 & 74550.66 \\
\hline 5311 & East Nusa Tenggara & Ende & 223173.15 & 106112.75 & 6973 & 99139.75 \\
\hline 5312 & East Nusa Tenggara & Ngada & 300446.53 & 134999.01 & 11604 & 123395.01 \\
\hline 5313 & East Nusa Tenggara & Manggarai & 690517.74 & 259288.96 & 50286 & 209002.96 \\
\hline 5314 & East Nusa Tenggara & Rote Ndao & 129459.90 & 78164.79 & 20689 & 57475.79 \\
\hline 6101 & West Kalimantan & Sambas & 597606.92 & 276856.01 & 71060 & 205796.01 \\
\hline 6102 & West Kalimantan & Bengkayang & 556461.70 & 310182.27 & 55275 & 254907.27 \\
\hline 6103 & West Kalimantan & Landak & 863235.80 & 561528.12 & 120105 & 441423.12 \\
\hline 6104 & West Kalimantan & Pontianak & 1086192.77 & 256058.65 & 78291 & 177767.65 \\
\hline 6105 & West Kalimantan & Sanggau & 1871739.99 & 1328911.37 & 110187 & 1218724.37 \\
\hline 6106 & West Kalimantan & Ketapang & 3486219.35 & 1092728.97 & 107051 & 985677.97 \\
\hline 6107 & West Kalimantan & Sintang & 3266001.17 & 1543802.10 & 35673 & 1508129.10 \\
\hline 6108 & West Kalimantan & Kapuas Hulu & 3096121.20 & 358823.10 & 38713 & 320110.10 \\
\hline 6201 & Central Kalimantan & Kotawaringin Barat & 1133284.48 & 268256.57 & 22554 & 245702.57 \\
\hline 6202 & Central Kalimantan & Kotawaringin Timur & 1620839.93 & 254065.26 & 57834 & 196231.26 \\
\hline 6203 & Central Kalimantan & Kapuas & 1487330.68 & 380057.75 & 189381 & 190676.75 \\
\hline 6204 & Central Kalimantan & Barito Selatan & 440520.79 & 87010.82 & 14660 & 72350.82 \\
\hline 6205 & Central Kalimantan & Barito Utara & 1131246.74 & 187878.03 & 23970 & 163908.03 \\
\hline 6206 & Central Kalimantan & Sukamara & 379524.15 & 167402.40 & 7371 & 160031.40 \\
\hline 6207 & Central Kalimantan & Lamandau & 491652.36 & 72944.89 & 3189 & 69755.89 \\
\hline 6208 & Central Kalimantan & Seruyan & 1442729.86 & 265923.74 & 11359 & 254564.74 \\
\hline 6209 & Central Kalimantan & Katingan & 2079164.94 & 121055.00 & 75328 & 45727.00 \\
\hline 6210 & Central Kalimantan & Pulang Pisau & 1168506.44 & 415823.47 & 67623 & 348200.47 \\
\hline 6211 & Central Kalimantan & Gunung Mas & 859684.13 & 172469.07 & 10210 & 162259.07 \\
\hline 6212 & Central Kalimantan & Barito Timur & 386628.67 & 201199.93 & 17741 & 183458.93 \\
\hline 6213 & Central Kalimantan & Murung Raya & 2417461.28 & 167844.35 & 1509 & 166335.35 \\
\hline 6301 & South Kalimantan & Tanah Laut & 385743.46 & 227923.30 & 49943 & 177980.30 \\
\hline 6302 & South Kalimantan & Kota Baru & 1427631.57 & 433231.43 & 80242 & 352989.43 \\
\hline 6303 & South Kalimantan & Banjar & 482190.86 & 228293.98 & 70210 & 158083.98 \\
\hline 6304 & South Kalimantan & Barito Kuala & 233661.47 & 165765.45 & 113512 & 52253.45 \\
\hline 6305 & South Kalimantan & Tapin & 216893.93 & 180386.46 & 115310 & 65076.46 \\
\hline 6306 & South Kalimantan & Hulu Sungai Selatan & 165397.75 & 133584.35 & 53670 & 79914.35 \\
\hline 6307 & South Kalimantan & Hulu Sungai Tengah & 118848.64 & 91166.06 & 45235 & 45931.06 \\
\hline 6308 & South Kalimantan & Hulu Sungai Utara & 293569.96 & 178220.61 & 66707 & 111513.61 \\
\hline 6309 & South Kalimantan & Tabalong & 361561.78 & 185832.42 & 31550 & 154282.42 \\
\hline 6401 & East Kalimantan & Pasir & 1085759.13 & 194900.83 & 29389 & 165511.83 \\
\hline 6402 & East Kalimantan & Kutai Barat & 3431876.14 & 514343.16 & 52606 & 461737.16 \\
\hline 6403 & East Kalimantan & Kutai Kertanegara & 2617197.75 & 1130204.85 & 69644 & 1060560.85 \\
\hline 6404 & East Kalimantan & Kutai Timur & 2835565.79 & 1013653.92 & 21633 & 992020.92 \\
\hline 6405 & East Kalimantan & Berau & 2113705.09 & 116512.18 & 8577 & 107935.18 \\
\hline 6406 & East Kalimantan & Malinau & 3854502.72 & 35666.49 & 4001 & 31665.49 \\
\hline 6407 & East Kalimantan & Bulongan & 1581043.95 & 98180.67 & 15894 & 82286.67 \\
\hline 6408 & East Kalimantan & Nunukan & 1583268.28 & 31029.67 & 7827 & 23202.67 \\
\hline 6409 & East Kalimantan & Penajam Paser Utara & 336955.44 & 100261.62 & 29760 & 70501.62 \\
\hline 7101 & North Sulawesi & Bolaang Mengondow & 782361.51 & 124042.95 & 44071 & 79971.95 \\
\hline 7102 & North Sulawesi & Minahasa & 451686.25 & 200169.44 & 21994 & 178175.44 \\
\hline 7103 & North Sulawesi & $\begin{array}{l}\text { Kepulauan Sangihe } \\
\text { Talaud }\end{array}$ & 92188.71 & 12318.56 & 302 & 12016.56 \\
\hline 7104 & North Sulawesi & Kepulauan Talaud & 105007.05 & 11325.40 & 2787 & 8538.40 \\
\hline 7201 & Central Sulawesi & Banggai Kepulauan & 316194.64 & 67697.12 & 4850 & 62847.12 \\
\hline 7202 & Central Sulawesi & Banggai & 909612.95 & 114428.56 & 24672 & 89756.56 \\
\hline 7203 & Central Sulawesi & Morowali & 1306925.84 & 102924.58 & 34662 & 68262.58 \\
\hline 7204 & Central Sulawesi & Poso & 1192920.97 & 125928.58 & 37918 & 88010.58 \\
\hline
\end{tabular}




\begin{tabular}{|c|c|c|c|c|c|c|}
\hline $\begin{array}{l}\text { District } \\
\text { Code }\end{array}$ & Province & District & $\begin{array}{l}\text { District area } \\
\text { (ha) }\end{array}$ & $\begin{array}{l}\text { "Kyotoland" } \\
\text { (ha) }\end{array}$ & $\begin{array}{c}\text { Ricefield } \\
\text { (ha) }\end{array}$ & $\begin{array}{c}\text { Eligible land } \\
\text { (ha)* }\end{array}$ \\
\hline 7205 & Central Sulawesi & Donggala & 936916.68 & 113760.18 & 72253 & 41507.18 \\
\hline 7206 & Central Sulawesi & Toli-Toli & 361970.94 & 45347.61 & 19148 & 26199.61 \\
\hline 7207 & Central Sulawesi & Buol & 401081.13 & 41613.63 & 9233 & 32380.63 \\
\hline 7208 & Central Sulawesi & Parigi Moutong & 628871.45 & 113778.63 & 350 & 113428.63 \\
\hline 7301 & South Sulawesi & Selayar & 121445.57 & 21236.39 & 2420 & 18816.39 \\
\hline 7302 & South Sulawesi & Bulukumba & 114787.00 & 76993.03 & 24595 & 52398.03 \\
\hline 7303 & South Sulawesi & Bantaeng & 39130.42 & 27228.15 & 6888 & 20340.15 \\
\hline 7304 & South Sulawesi & Jeneponto & 67073.50 & 46993.52 & 19082 & 27911.52 \\
\hline 7305 & South Sulawesi & Takalar & 63882.50 & 43147.08 & 16610 & 26537.08 \\
\hline 7306 & South Sulawesi & Gowa & 175826.86 & 104139.23 & 50605 & 53534.23 \\
\hline 7307 & South Sulawesi & Sinjai & 85161.17 & 62604.13 & 13622 & 48982.13 \\
\hline 7308 & South Sulawesi & Maros & 160650.80 & 71310.04 & 30257 & 41053.04 \\
\hline 7309 & South Sulawesi & Pangkajene Kepulauan & 96301.76 & 37848.89 & 18591 & 19257.89 \\
\hline 7310 & South Sulawesi & Barru & 118038.53 & 36650.92 & 13302 & 23348.92 \\
\hline 7311 & South Sulawesi & Bone & 454959.76 & 320425.22 & 111992 & 208433.22 \\
\hline 7312 & South Sulawesi & Soppeng & 136237.24 & 72378.22 & 25035 & 47343.22 \\
\hline 7313 & South Sulawesi & Wajo & 247660.72 & 130736.35 & 89830 & 40906.35 \\
\hline 7314 & South Sulawesi & Sidenreng Rappang & 193180.38 & 92225.61 & 45425 & 46800.61 \\
\hline 7315 & South Sulawesi & Pinrang & 190039.08 & 77143.22 & 45898 & 31245.22 \\
\hline 7316 & South Sulawesi & Enrekang & 180852.48 & 64975.08 & 8407 & 56568.08 \\
\hline 7317 & South Sulawesi & Luwu & 312644.37 & 90908.84 & 41787 & 49121.84 \\
\hline 7318 & South Sulawesi & Tana Toraja & 341646.47 & 63084.00 & 31610 & 31474.00 \\
\hline 7319 & South Sulawesi & Polewali Mamasa & 199879.16 & 56487.72 & 29893 & 26594.72 \\
\hline 7320 & South Sulawesi & Majene & 102020.79 & 15835.01 & 1501 & 14334.01 \\
\hline 7321 & South Sulawesi & Mamuju & 1049566.31 & 43264.50 & 31541 & 11723.50 \\
\hline 7322 & South Sulawesi & Luwu Utara & 1490796.59 & 145271.39 & 101036 & 44235.39 \\
\hline 7323 & South Sulawesi & Mamasa & 273979.94 & 26092.02 & & 26092.02 \\
\hline 7401 & Southeast Sulawesi & Buton & 693722.57 & 196655.42 & 17276 & 179379.42 \\
\hline 7402 & Southeast Sulawesi & Muna & 444887.83 & 134049.92 & 3529 & 130520.92 \\
\hline 7403 & Southeast Sulawesi & Kendari & 1609999.56 & 303242.81 & 73841 & 229401.81 \\
\hline 7404 & Southeast Sulawesi & Kolaka & 927909.94 & 62128.04 & 31582 & 30546.04 \\
\hline 7501 & Gorontalo & Boalemo & 638481.28 & 71754.36 & 13215 & 58539.36 \\
\hline 7502 & Gorontalo & Gorontalo & 579720.74 & 166919.23 & 21560 & 145359.23 \\
\hline 8101 & Maluku & Maluku Tenggara Barat & 944052.12 & 106567.80 & 0 & 106567.80 \\
\hline 8102 & Maluku & Maluku Tenggara & 1027840.28 & 77710.63 & 0 & 77710.63 \\
\hline 8103 & Maluku & Maluku Tengah & 2033066.75 & 80094.63 & 27011 & 53083.63 \\
\hline 8104 & Maluku & Buru & 891900.93 & 117775.97 & 23915 & 93860.97 \\
\hline 8171 & Maluku & Ambon & 30833.39 & 1983.91 & 0 & 1983.91 \\
\hline 8201 & North Maluku & Maluku Utara & 2152622.03 & 57580.94 & 2100 & 55480.94 \\
\hline 8202 & North Maluku & Halmahera Tengah & 1096252.73 & 13870.83 & 5523 & 8347.83 \\
\hline 9101 & Papua & Merauke & 5174572.66 & 1876219.09 & n.a. & 1876219.09 \\
\hline 9102 & Papua & Jayawijaya & 1775305.39 & 232955.92 & n.a. & 232955.92 \\
\hline 9104 & Papua & Nabire & 1902478.81 & 28591.16 & n.a. & 28591.16 \\
\hline 9106 & Papua & Puncak Jaya & 1456299.76 & 124858.62 & n.a. & 124858.62 \\
\hline 9107 & Papua & Fak-Fak & 1187456.74 & 72189.21 & n.a. & 72189.21 \\
\hline 9108 & Papua & Mimika & 2449449.30 & 57445.98 & n.a. & 57445.98 \\
\hline 9110 & Papua & Manokwari & 1537108.74 & 61038.34 & n.a. & 61038.34 \\
\hline 9112 & Papua & Biak Numfor & 346336.46 & 11160.27 & n.a. & 11160.27 \\
\hline 9171 & Papua & Jayapura & 1430215.90 & 47002.37 & n.a. & 47002.37 \\
\hline 9405 & Papua & Paniai & 1244760.99 & 59951.99 & n.a. & 59951.99 \\
\hline 9413 & Papua & Boven Digoel & 2876588.58 & 148443.44 & n.a. & 148443.44 \\
\hline 9414 & Papua & Mappi & 2270697.97 & 800647.02 & n.a. & 800647.02 \\
\hline 9415 & Papua & Asmat & 3681256.78 & 458835.84 & n.a. & 458835.84 \\
\hline 9416 & Papua & Yahukimo & 1821982.02 & 65244.05 & n.a. & 65244.05 \\
\hline
\end{tabular}




\begin{tabular}{|c|c|c|c|c|c|c|}
\hline $\begin{array}{l}\text { District } \\
\text { Code }\end{array}$ & Province & District & $\begin{array}{l}\text { District area } \\
\text { (ha) }\end{array}$ & $\begin{array}{l}\text { "Kyotoland" } \\
\text { (ha) }\end{array}$ & $\begin{array}{c}\text { Ricefield } \\
\text { (ha) }\end{array}$ & $\begin{array}{c}\text { Eligible land } \\
\text { (ha)* }\end{array}$ \\
\hline 9417 & Papua & Pegunungan Bintang & 1911412.45 & 26168.14 & n.a. & 26168.14 \\
\hline 9418 & Papua & Tolikara & 643303.26 & 57767.53 & n.a. & 57767.53 \\
\hline 9419 & Papua & Sarmi & 2923724.29 & 109305.99 & n.a. & 109305.99 \\
\hline 9420 & Papua & Keerom & 1212944.47 & 39490.24 & n.a. & 39490.24 \\
\hline 9421 & Papua & Kaimana & 1767661.90 & 7007.16 & n.a. & 7007.16 \\
\hline 9422 & Papua & Sorong & 1412621.57 & 23326.80 & n.a. & 23326.80 \\
\hline 9424 & Papua & Teluk Bintuni & 2254368.37 & 24387.57 & n.a. & 24387.57 \\
\hline 9425 & Papua & Teluk Wondama & 443712.49 & 6640.21 & n.a. & 6640.21 \\
\hline 9426 & Papua & Waropen & 3137820.95 & 84543.87 & n.a. & 84543.87 \\
\hline
\end{tabular}

*) Note: Negative figures indicate data discrepancies in the rice field areas (taken from the District Statistics Office).

They may have used harvest area which can be doubled or triplet depending on the number of harvest per year 
Appendix 2. Population density and Human Development index by district

\begin{tabular}{|c|c|c|c|c|c|c|}
\hline $\begin{array}{c}\text { District } \\
\text { Code }\end{array}$ & Province & District & $\begin{array}{c}\text { Population density } \\
\text { (persons } / \mathbf{k m}^{2} \text { ) }\end{array}$ & $\begin{array}{c}\text { Population } \\
\text { density class }\end{array}$ & HDI 2002 & HDI class \\
\hline 1101 & $\begin{array}{l}\text { Nanggroe Aceh } \\
\text { Darussalam }\end{array}$ & Simeulue & 36.87 & 2 & 62 & 2 \\
\hline 1102 & $\begin{array}{l}\text { Nanggroe Aceh } \\
\text { Darussalam }\end{array}$ & Aceh Singkil & 47.44 & 2 & 62 & 2 \\
\hline 1103 & $\begin{array}{l}\text { Nanggroe Aceh } \\
\text { Darussalam }\end{array}$ & Aceh Selatan & 41.84 & 2 & 64 & 2 \\
\hline 1104 & $\begin{array}{l}\text { Nanggroe Aceh } \\
\text { Darussalam }\end{array}$ & Aceh Tenggara & 34.64 & 2 & 67 & 3 \\
\hline 1105 & $\begin{array}{l}\text { Nanggroe Aceh } \\
\text { Darussalam }\end{array}$ & Aceh Timur & 42.67 & 2 & 67 & 3 \\
\hline 1106 & $\begin{array}{l}\text { Nanggroe Aceh } \\
\text { Darussalam }\end{array}$ & Aceh Tengah & 38.03 & 2 & 67 & 3 \\
\hline 1107 & $\begin{array}{l}\text { Nanggroe Aceh } \\
\text { Darussalam }\end{array}$ & Aceh Barat & 64.02 & 2 & 66 & 2 \\
\hline 1108 & $\begin{array}{l}\text { Nanggroe Aceh } \\
\text { Darussalam }\end{array}$ & Aceh Besar & 93.18 & 2 & 67 & 3 \\
\hline 1109 & $\begin{array}{l}\text { Nanggroe Aceh } \\
\text { Darussalam }\end{array}$ & Pidie & 109.33 & 3 & 68 & 3 \\
\hline 1110 & $\begin{array}{l}\text { Nanggroe Aceh } \\
\text { Darussalam }\end{array}$ & Bireuen & 183.28 & 3 & 71 & 3 \\
\hline 1111 & $\begin{array}{l}\text { Nanggroe Aceh } \\
\text { Darussalam }\end{array}$ & Aceh Utara & 146.50 & 3 & 66 & 2 \\
\hline 1112 & $\begin{array}{l}\text { Nanggroe Aceh } \\
\text { Darussalam }\end{array}$ & Aceh Barat Daya & 59.86 & 2 & 67 & 3 \\
\hline 1113 & $\begin{array}{l}\text { Nanggroe Aceh } \\
\text { Darussalam }\end{array}$ & Gayo Lues & 13.47 & 2 & 67 & 3 \\
\hline 1114 & $\begin{array}{l}\text { Nanggroe Aceh } \\
\text { Darussalam }\end{array}$ & Aceh Tamiang & 97.04 & 2 & 67 & 3 \\
\hline 1115 & $\begin{array}{l}\text { Nanggroe Aceh } \\
\text { Darussalam }\end{array}$ & Nagan Raya & 39.33 & 2 & 66 & 2 \\
\hline 1116 & $\begin{array}{l}\text { Nanggroe Aceh } \\
\text { Darussalam }\end{array}$ & Aceh Jaya & 21.61 & 2 & 67 & 3 \\
\hline 1201 & North Sumatra & Labuhan Batu & 32.21 & 2 & 62 & 2 \\
\hline 1202 & North Sumatra & Mandailing Natal & 52.87 & 2 & 64 & 2 \\
\hline 1203 & North Sumatra & Tapanuli Selatan & 46.95 & 2 & 68 & 3 \\
\hline 1204 & North Sumatra & Tapanuli Tengah & 102.69 & 3 & 66 & 2 \\
\hline 1205 & North Sumatra & Tapanuli Utara & 39.64 & 2 & 67 & 3 \\
\hline 1206 & North Sumatra & Toba Samosir & 69.72 & 2 & 70 & 3 \\
\hline 1208 & North Sumatra & Asahan & 193.31 & 3 & 67 & 3 \\
\hline 1209 & North Sumatra & Simalungun & 164.07 & 3 & 68 & 3 \\
\hline 1210 & North Sumatra & Dairi & 52.02 & 2 & 67 & 3 \\
\hline 1211 & North Sumatra & Karo & 126.96 & 3 & 71 & 3 \\
\hline 1212 & North Sumatra & Deli Serdang & 404.81 & 4 & 68 & 3 \\
\hline 1213 & North Sumatra & Langkat & 135.99 & 3 & 68 & 3 \\
\hline 1301 & West Sumatra & Kepulauan Mentawai & 10.17 & 2 & 64 & 2 \\
\hline 1302 & West Sumatra & Pesisir Selatan & 64.23 & 2 & 66 & 2 \\
\hline 1303 & West Sumatra & Solok & 61.72 & 2 & 64 & 2 \\
\hline 1304 & West Sumatra & Sawahlunto/Sijunjung & 53.71 & 2 & 62 & 2 \\
\hline 1305 & West Sumatra & Tanah Datar & 224.77 & 3 & 68 & 3 \\
\hline 1306 & West Sumatra & Padang Pariaman & 213.50 & 3 & 66 & 2 \\
\hline 1307 & West Sumatra & Agam & 172.60 & 3 & 68 & 3 \\
\hline 1308 & West Sumatra & Lima Puluh Koto & 103.34 & 3 & 67 & 3 \\
\hline 1309 & West Sumatra & Pasaman & 64.54 & 2 & 64 & 2 \\
\hline 1401 & Riau & Kuantan Singingi & 43.61 & 2 & 67 & 3 \\
\hline 1402 & Riau & Indragiri Hulu & 33.71 & 2 & 66 & 2 \\
\hline
\end{tabular}




\begin{tabular}{|c|c|c|c|c|c|c|}
\hline $\begin{array}{c}\text { District } \\
\text { Code }\end{array}$ & Province & District & $\begin{array}{c}\text { Population density } \\
\text { (persons/(km²) }\end{array}$ & $\begin{array}{l}\text { Population } \\
\text { density class }\end{array}$ & HDI 2002 & HDI class \\
\hline 1403 & Riau & Indragiri Hilir & 47.89 & 2 & 68 & 3 \\
\hline 1404 & Riau & Pelalawan & 14.83 & 2 & 66 & 2 \\
\hline 1405 & Riau & Siak & 31.65 & 2 & 71 & 3 \\
\hline 1406 & Riau & Kampar & 46.40 & 2 & 68 & 3 \\
\hline 1407 & Riau & Rokan Hulu & 39.66 & 2 & 64 & 2 \\
\hline 1408 & Riau & Bengkalis & 50.74 & 2 & 69 & 3 \\
\hline 1409 & Riau & Rokan Hilir & 41.14 & 2 & 66 & 2 \\
\hline 1410 & Riau & Kepulauan Riau & 44.82 & 2 & 67 & 3 \\
\hline 1411 & Riau & Karimun & 186.31 & 3 & 69 & 3 \\
\hline 1412 & Riau & Natuna & 30.28 & 2 & 65 & 2 \\
\hline 1501 & Jambi & Kerinci & 75.41 & 2 & 68 & 3 \\
\hline 1502 & Jambi & Merangin & 36.61 & 2 & 66 & 2 \\
\hline 1503 & Jambi & Sarolangun & 26.94 & 2 & 65 & 2 \\
\hline 1504 & Jambi & Batanghari & 33.35 & 2 & 67 & 3 \\
\hline 1505 & Jambi & Muara Jambi & 54.18 & 2 & 67 & 3 \\
\hline 1506 & Jambi & Tanjung Jabung Timur & 38.93 & 2 & 65 & 2 \\
\hline 1507 & Jambi & Tanjung Jabung Barat & 38.31 & 2 & 68 & 3 \\
\hline 1508 & Jambi & Tebo & 34.43 & 2 & 65 & 2 \\
\hline 1509 & Jambi & Bungo & 47.96 & 2 & 64 & 2 \\
\hline 1601 & South Sumatra & Ogan Komering Ulu & 100.67 & 3 & 67 & 3 \\
\hline 1602 & South Sumatra & Ogan Komering Ilir & 47.88 & 2 & 63 & 2 \\
\hline 1603 & South Sumatra & Muara Enim & 73.30 & 2 & 64 & 2 \\
\hline 1604 & South Sumatra & Lahat & 74.96 & 2 & 65 & 2 \\
\hline 1605 & South Sumatra & Musi Rawas & 36.06 & 2 & 62 & 2 \\
\hline 1606 & South Sumatra & Musi Banyu Asin & 27.87 & 2 & 65 & 2 \\
\hline 1607 & South Sumatra & Banyu Asin & 54.79 & 2 & 65 & 2 \\
\hline 1701 & Bengkulu & Bengkulu Selatan & 17.39 & 2 & 65 & 2 \\
\hline 1702 & Bengkulu & Rejang Lebong & 105.66 & 3 & 64 & 2 \\
\hline 1703 & Bengkulu & Bengkulu Utara & 30.59 & 2 & 64 & 2 \\
\hline 1801 & Lampung & Lampung Barat & 72.46 & 2 & 63 & 2 \\
\hline 1802 & Lampung & Tanggamus & 214.67 & 3 & 66 & 2 \\
\hline 1803 & Lampung & Lampung Selatan & 259.53 & 3 & 64 & 2 \\
\hline 1804 & Lampung & Lampung Timur & 309.40 & 4 & 66 & 2 \\
\hline 1805 & Lampung & Lampung Tengah & 240.48 & 3 & 67 & 3 \\
\hline 1806 & Lampung & Lampung Utara & 227.66 & 3 & 66 & 2 \\
\hline 1807 & Lampung & Way Kanan & 89.64 & 2 & 65 & 2 \\
\hline 1808 & Lampung & Tulang Bawang & 101.33 & 3 & 64 & 2 \\
\hline 1901 & $\begin{array}{l}\text { Kepulauan Bangka } \\
\text { - Belitung }\end{array}$ & Bangka & 68.87 & 2 & 65 & 2 \\
\hline 1902 & $\begin{array}{l}\text { Kepulauan Bangka } \\
\text { - Belitung }\end{array}$ & Belitung & 55.03 & 2 & 67 & 3 \\
\hline 1903 & $\begin{array}{l}\text { Kepulauan Bangka } \\
\text { - Belitung }\end{array}$ & Bangka Barat & 44.88 & 2 & 65 & 2 \\
\hline 1904 & $\begin{array}{l}\text { Kepulauan Bangka } \\
\text { - Belitung }\end{array}$ & Bangka Tengah & 60.44 & 2 & 65 & 2 \\
\hline 1905 & $\begin{array}{l}\text { Kepulauan Bangka } \\
\text { - Belitung }\end{array}$ & Bangka Selatan & 37.43 & 2 & 65 & 2 \\
\hline 1906 & $\begin{array}{l}\text { Kepulauan Bangka } \\
\text { - Belitung }\end{array}$ & Belitung Timur & 41.36 & 2 & 67 & 3 \\
\hline 3201 & West Java & Bogor & 258.47 & 3 & 66 & 2 \\
\hline 3202 & West Java & Sukabumi & 506.11 & 4 & 64 & 2 \\
\hline 3203 & West Java & Cianjur & 646.71 & 4 & 65 & 2 \\
\hline 3204 & West Java & Bandung & 709.36 & 4 & 69 & 3 \\
\hline 3205 & West Java & Garut & 693.06 & 4 & 63 & 2 \\
\hline 3206 & West Java & Tasikmalaya & 564.16 & 4 & 67 & 3 \\
\hline
\end{tabular}




\begin{tabular}{|c|c|c|c|c|c|c|}
\hline $\begin{array}{l}\text { District } \\
\text { Code }\end{array}$ & Province & District & $\begin{array}{c}\text { Population density } \\
\text { (persons } / \mathbf{k m}^{2} \text { ) }\end{array}$ & $\begin{array}{c}\text { Population } \\
\text { density class }\end{array}$ & HDI 2002 & HDI class \\
\hline 3207 & West Java & Ciamis & 540.52 & 4 & 65 & 2 \\
\hline 3208 & West Java & Kuningan & 830.12 & 4 & 65 & 2 \\
\hline 3209 & West Java & Cirebon & 1899.14 & 4 & 62 & 2 \\
\hline 3210 & West Java & Majalengka & 859.56 & 4 & 64 & 2 \\
\hline 3211 & West Java & Sumedang & 629.64 & 4 & 68 & 3 \\
\hline 3212 & West Java & Indramayu & 787.89 & 4 & 61 & 2 \\
\hline 3213 & West Java & Subang & 619.07 & 4 & 63 & 2 \\
\hline 3214 & West Java & Purwakarta & 764.32 & 4 & 66 & 2 \\
\hline 3215 & West Java & Karawang & 948.47 & 4 & 63 & 2 \\
\hline 3216 & West Java & Bekasi & 1433.19 & 4 & 67 & 3 \\
\hline 3301 & Central Java & Cilacap & 710.96 & 4 & 65 & 2 \\
\hline 3302 & Central Java & Banyumas & 1051.30 & 4 & 67 & 3 \\
\hline 3303 & Central Java & Purbalingga & 1024.53 & 4 & 65 & 2 \\
\hline 3304 & Central Java & Banjarnegara & 760.46 & 4 & 64 & 2 \\
\hline 3305 & Central Java & Kebumen & 888.49 & 4 & 66 & 2 \\
\hline 3306 & Central Java & Purworejo & 648.06 & 4 & 68 & 3 \\
\hline 3307 & Central Java & Wonosobo & 755.14 & 4 & 65 & 2 \\
\hline 3308 & Central Java & Magelang & 104.43 & 3 & 67 & 3 \\
\hline 3309 & Central Java & Boyolali & 836.49 & 4 & 66 & 2 \\
\hline 3310 & Central Java & Klaten & 1664.04 & 4 & 68 & 3 \\
\hline 3311 & Central Java & Sukoharjo & 1566.39 & 4 & 68 & 3 \\
\hline 3312 & Central Java & Wonogiri & 521.87 & 4 & 67 & 3 \\
\hline 3313 & Central Java & Karanganyar & 991.15 & 4 & 69 & 3 \\
\hline 3314 & Central Java & Sragen & 876.06 & 4 & 65 & 2 \\
\hline 3315 & Central Java & Grobogan/Purwodadi & 649.84 & 4 & 66 & 2 \\
\hline 3316 & Central Java & Blora & 421.78 & 4 & 65 & 2 \\
\hline 3317 & Central Java & Rembang & 539.75 & 4 & 66 & 2 \\
\hline 3318 & Central Java & Pati & 743.14 & 4 & 69 & 3 \\
\hline 3319 & Central Java & Kudus & 1728.25 & 4 & 67 & 3 \\
\hline 3320 & Central Java & Jepara & 960.33 & 4 & 67 & 3 \\
\hline 3321 & Central Java & Demak & 1035.94 & 4 & 66 & 2 \\
\hline 3322 & Central Java & Semarang & 1350.52 & 4 & 70 & 3 \\
\hline 3323 & Central Java & Temanggung & 779.09 & 4 & 70 & 3 \\
\hline 3324 & Central Java & Kendal & 859.97 & 4 & 66 & 2 \\
\hline 3325 & Central Java & Batang & 923.24 & 4 & 66 & 2 \\
\hline 3326 & Central Java & Pekalongan & 300.28 & 4 & 64 & 2 \\
\hline 3327 & Central Java & Pemalang & 1157.62 & 4 & 62 & 2 \\
\hline 3328 & Central Java & Tegal & 1426.21 & 4 & 63 & 2 \\
\hline 3329 & Central Java & Brebes & 1002.22 & 4 & 61 & 2 \\
\hline 3401 & DI Yogyakarta & Kulon Progo & 614.55 & 4 & 69 & 3 \\
\hline 3402 & DI Yogyakarta & Bantul & 1657.00 & 4 & 68 & 3 \\
\hline 3403 & DI Yogyakarta & Gunung Kidul & 464.40 & 4 & 67 & 3 \\
\hline 3404 & DI Yogyakarta & Sleman & 1635.68 & 4 & 73 & 3 \\
\hline 3501 & East Java & Pacitan & 377.16 & 4 & 66 & 2 \\
\hline 3502 & East Java & Ponorogo & 599.37 & 4 & 63 & 2 \\
\hline 3503 & East Java & Trenggalek & 532.18 & 4 & 68 & 3 \\
\hline 3504 & East Java & Tulungagung & 824.74 & 4 & 68 & 3 \\
\hline 3505 & East Java & Blitar & 635.65 & 4 & 67 & 3 \\
\hline 3506 & East Java & Kediri & 162.18 & 3 & 66 & 2 \\
\hline 3507 & East Java & Malang & 661.89 & 4 & 65 & 2 \\
\hline 3508 & East Java & Lumajang & 552.27 & 4 & 61 & 2 \\
\hline 3509 & East Java & Jember & 663.86 & 4 & 58 & 2 \\
\hline 3510 & East Java & Banyuwangi & 434.50 & 4 & 63 & 2 \\
\hline 3511 & East Java & Bondowoso & 455.64 & 4 & 54 & 2 \\
\hline
\end{tabular}




\begin{tabular}{|c|c|c|c|c|c|c|}
\hline $\begin{array}{l}\text { District } \\
\text { Code }\end{array}$ & Province & District & $\begin{array}{l}\text { Population density } \\
\text { (persons } / \mathbf{k m}^{2} \text { ) }\end{array}$ & $\begin{array}{l}\text { Population } \\
\text { density class }\end{array}$ & HDI 2002 & HDI class \\
\hline 3512 & East Java & Situbondo & 382.48 & 4 & 56 & 2 \\
\hline 3513 & East Java & Probolinggo & 598.84 & 4 & 57 & 2 \\
\hline 3514 & East Java & Pasuruan & 117.86 & 3 & 62 & 2 \\
\hline 3515 & East Java & Sidoarjo & 2438.50 & 4 & 72 & 3 \\
\hline 3516 & East Java & Mojokerto & 111.91 & 3 & 68 & 3 \\
\hline 3517 & East Java & Jombang & 1068.21 & 4 & 66 & 2 \\
\hline 3518 & East Java & Nganjuk & 797.44 & 4 & 65 & 2 \\
\hline 3519 & East Java & Madiun & 150.87 & 3 & 64 & 2 \\
\hline 3520 & East Java & Magetan & 855.87 & 4 & 67 & 3 \\
\hline 3521 & East Java & Ngawi & 595.87 & 4 & 62 & 2 \\
\hline 3522 & East Java & Bojonegoro & 513.27 & 4 & 61 & 2 \\
\hline 3523 & East Java & Tuban & 540.57 & 4 & 61 & 2 \\
\hline 3524 & East Java & Lamongan & 695.48 & 4 & 64 & 2 \\
\hline 3525 & East Java & Gresik & 861.96 & 4 & 69 & 3 \\
\hline 3526 & East Java & Bangkalan & 675.14 & 4 & 58 & 2 \\
\hline 3527 & East Java & Sampang & 673.14 & 4 & 50 & 1 \\
\hline 3528 & East Java & Pamekasan & 917.84 & 4 & 58 & 2 \\
\hline 3529 & East Java & Sumenep & 477.65 & 4 & 57 & 2 \\
\hline 3601 & Banten & Pandeglang & 373.09 & 4 & 63 & 2 \\
\hline 3602 & Banten & Lebak & 334.94 & 4 & 62 & 2 \\
\hline 3603 & Banten & Tangerang & 2674.18 & 4 & 68 & 3 \\
\hline 3604 & Banten & Serang & 970.67 & 4 & 64 & 2 \\
\hline 5101 & Bali & Jembrana & 292.52 & 3 & 69 & 3 \\
\hline 5102 & Bali & Tabanan & 464.15 & 4 & 70 & 3 \\
\hline 5103 & Bali & Badung & 1025.64 & 4 & 70 & 3 \\
\hline 5104 & Bali & Gianyar & 1141.66 & 4 & 68 & 3 \\
\hline 5105 & Bali & Klungkung & 530.80 & 4 & 65 & 2 \\
\hline 5106 & Bali & Bangli & 397.22 & 4 & 67 & 3 \\
\hline 5107 & Bali & Karangasem & 460.23 & 4 & 59 & 2 \\
\hline 5108 & Bali & Buleleng & 456.73 & 4 & 64 & 2 \\
\hline 5201 & West Nusa Tenggara & Lombok Barat & 411.13 & 4 & 55 & 2 \\
\hline 5202 & West Nusa Tenggara & Lombok Tengah & 614.46 & 4 & 54 & 2 \\
\hline 5203 & West Nusa Tenggara & Lombok Timur & 673.67 & 4 & 56 & 2 \\
\hline 5204 & West Nusa Tenggara & Sumbawa & 54.82 & 2 & 61 & 2 \\
\hline 5205 & West Nusa Tenggara & Dompu & 87.15 & 2 & 58 & 2 \\
\hline 5206 & West Nusa Tenggara & Bima & 93.28 & 2 & 59 & 2 \\
\hline 5301 & East Nusa Tenggara & Sumba Barat & 97.55 & 2 & 53 & 2 \\
\hline 5302 & East Nusa Tenggara & Sumba Timur & 28.73 & 2 & 57 & 2 \\
\hline 5303 & East Nusa Tenggara & Kupang & 59.66 & 2 & 57 & 2 \\
\hline 5304 & East Nusa Tenggara & Timor Tengah Selatan & 98.50 & 2 & 58 & 2 \\
\hline 5305 & East Nusa Tenggara & Timor Tengah Utara & 75.05 & 2 & 60 & 2 \\
\hline 5306 & East Nusa Tenggara & Belu & 147.79 & 3 & 58 & 2 \\
\hline 5307 & East Nusa Tenggara & Alor & 55.83 & 2 & 57 & 2 \\
\hline 5308 & East Nusa Tenggara & Lembata & 75.87 & 2 & 62 & 2 \\
\hline 5309 & East Nusa Tenggara & Flores Timur & 119.94 & 3 & 63 & 2 \\
\hline 5310 & East Nusa Tenggara & Sikka & 153.06 & 3 & 58 & 2 \\
\hline 5311 & East Nusa Tenggara & Ende & 105.94 & 3 & 61 & 2 \\
\hline 5312 & East Nusa Tenggara & Ngada & 78.96 & 2 & 64 & 2 \\
\hline 5313 & East Nusa Tenggara & Manggarai & 68.70 & 2 & 60 & 2 \\
\hline 5314 & East Nusa Tenggara & Rote Ndao & 78.09 & 2 & & 1 \\
\hline 6101 & West Kalimantan & Sambas & 79.07 & 2 & 59 & 2 \\
\hline 6102 & West Kalimantan & Bengkayang & 34.66 & 2 & 63 & 2 \\
\hline 6103 & West Kalimantan & Landak & 35.11 & 2 & 62 & 2 \\
\hline 6104 & West Kalimantan & Pontianak & 62.77 & 2 & 64 & 2 \\
\hline
\end{tabular}




\begin{tabular}{|c|c|c|c|c|c|c|}
\hline $\begin{array}{c}\text { District } \\
\text { Code }\end{array}$ & Province & District & $\begin{array}{c}\text { Population density } \\
\left(\text { persons } / \mathbf{k m}^{2}\right)\end{array}$ & $\begin{array}{l}\text { Population } \\
\text { density class }\end{array}$ & HDI 2002 & HDI class \\
\hline 6105 & West Kalimantan & Sanggau & 28.02 & 2 & 62 & 2 \\
\hline 6106 & West Kalimantan & Ketapang & 13.09 & 2 & 64 & 2 \\
\hline 6107 & West Kalimantan & Sintang & 14.56 & 2 & 62 & 2 \\
\hline 6108 & West Kalimantan & Kapuas Hulu & 6.31 & 1 & 63 & 2 \\
\hline 6201 & Central Kalimantan & Kotawaringin Barat & 16.48 & 2 & 69 & 3 \\
\hline 6202 & Central Kalimantan & Kotawaringin Timur & 17.29 & 2 & 68 & 3 \\
\hline 6203 & Central Kalimantan & Kapuas & 21.83 & 2 & 69 & 3 \\
\hline 6204 & Central Kalimantan & Barito Selatan & 25.80 & 2 & 68 & 3 \\
\hline 6205 & Central Kalimantan & Barito Utara & 9.50 & 1 & 70 & 3 \\
\hline 6206 & Central Kalimantan & Sukamara & 8.63 & 1 & 69 & 3 \\
\hline 6207 & Central Kalimantan & Lamandau & 9.76 & 1 & 69 & 3 \\
\hline 6208 & Central Kalimantan & Seruyan & 6.28 & 1 & 68 & 3 \\
\hline 6209 & Central Kalimantan & Katingan & 6.00 & 1 & 68 & 3 \\
\hline 6210 & Central Kalimantan & Pulang Pisau & 9.71 & 1 & 69 & 3 \\
\hline 6211 & Central Kalimantan & Gunung Mas & 9.56 & 1 & 69 & 3 \\
\hline 6212 & Central Kalimantan & Barito Timur & 19.59 & 2 & 68 & 3 \\
\hline 6213 & Central Kalimantan & Murung Raya & 3.42 & 1 & 69 & 3 \\
\hline 6301 & South Kalimantan & Tanah Laut & 63.88 & 2 & 66 & 2 \\
\hline 6302 & South Kalimantan & Kota Baru & 17.67 & 2 & 65 & 2 \\
\hline 6303 & South Kalimantan & Banjar & 33.63 & 2 & 64 & 2 \\
\hline 6304 & South Kalimantan & Barito Kuala & 111.81 & 3 & 61 & 2 \\
\hline 6305 & South Kalimantan & Tapin & 66.62 & 2 & 67 & 3 \\
\hline 6306 & South Kalimantan & Hulu Sungai Selatan & 120.70 & 3 & 65 & 2 \\
\hline 6307 & South Kalimantan & Hulu Sungai Tengah & 194.65 & 3 & 65 & 2 \\
\hline 6308 & South Kalimantan & Hulu Sungai Utara & 70.03 & 2 & 62 & 2 \\
\hline 6309 & South Kalimantan & Tabalong & 50.16 & 2 & 63 & 2 \\
\hline 6401 & East Kalimantan & Pasir & 15.65 & 2 & 68 & 3 \\
\hline 6402 & East Kalimantan & Kutai Barat & 4.18 & 1 & 68 & 3 \\
\hline 6403 & East Kalimantan & Kutai Kertanegara & 18.36 & 2 & 68 & 3 \\
\hline 6404 & East Kalimantan & Kutai Timur & 5.78 & 1 & 66 & 2 \\
\hline 6405 & East Kalimantan & Berau & 6.30 & 1 & 68 & 3 \\
\hline 6406 & East Kalimantan & Malinau & 1.21 & 1 & 64 & 2 \\
\hline 6407 & East Kalimantan & Bulongan & 5.99 & 1 & 70 & 3 \\
\hline 6408 & East Kalimantan & Nunukan & 6.57 & 1 & 68 & 3 \\
\hline 6409 & East Kalimantan & Penajam Paser Utara & 34.73 & 2 & 68 & 3 \\
\hline 7101 & North Sulawesi & Bolaang Mengondow & 58.51 & 2 & 69 & 3 \\
\hline 7102 & North Sulawesi & Minahasa & 101.39 & 3 & 72 & 3 \\
\hline 7103 & North Sulawesi & $\begin{array}{l}\text { Kepulauan Sangihe } \\
\text { Talaud }\end{array}$ & 208.29 & 3 & 70 & 3 \\
\hline 7104 & North Sulawesi & Kepulauan Talaud & 73.97 & 2 & & 1 \\
\hline 7201 & Central Sulawesi & Banggai Kepulauan & 47.04 & 2 & 61 & 2 \\
\hline 7202 & Central Sulawesi & Banggai & 30.94 & 2 & 66 & 2 \\
\hline 7203 & Central Sulawesi & Morowali & 12.45 & 2 & 65 & 2 \\
\hline 7204 & Central Sulawesi & Poso & 22.66 & 2 & 64 & 2 \\
\hline 7205 & Central Sulawesi & Donggala & 45.91 & 2 & 62 & 2 \\
\hline 7206 & Central Sulawesi & Toli-Toli & 52.30 & 2 & 64 & 2 \\
\hline 7207 & Central Sulawesi & Buol & 26.79 & 2 & 63 & 2 \\
\hline 7208 & Central Sulawesi & Parigi Moutong & 54.25 & 2 & & 1 \\
\hline 7301 & South Sulawesi & Selayar & 90.17 & 2 & 64 & 2 \\
\hline 7302 & South Sulawesi & Bulukumba & 323.38 & 4 & 64 & 2 \\
\hline 7303 & South Sulawesi & Bantaeng & 421.30 & 4 & 63 & 2 \\
\hline 7304 & South Sulawesi & Jeneponto & 481.76 & 4 & 58 & 2 \\
\hline 7305 & South Sulawesi & Takalar & 376.56 & 4 & 62 & 2 \\
\hline 7306 & South Sulawesi & Gowa & 313.91 & 4 & 64 & 2 \\
\hline
\end{tabular}




\begin{tabular}{|c|c|c|c|c|c|c|}
\hline $\begin{array}{c}\text { District } \\
\text { Code }\end{array}$ & Province & District & $\begin{array}{c}\text { Population density } \\
\text { (persons } / \mathbf{k m}^{2} \text { ) }\end{array}$ & $\begin{array}{l}\text { Population } \\
\text { density class }\end{array}$ & HDI 2002 & HDI class \\
\hline 7307 & South Sulawesi & Sinjai & 254.10 & 3 & 64 & 2 \\
\hline 7308 & South Sulawesi & Maros & 178.05 & 3 & 64 & 2 \\
\hline 7309 & South Sulawesi & Pangkajene Kepulauan & 297.03 & 3 & 64 & 2 \\
\hline 7310 & South Sulawesi & Barru & 132.87 & 3 & 66 & 2 \\
\hline 7311 & South Sulawesi & Bone & 149.45 & 3 & 63 & 2 \\
\hline 7312 & South Sulawesi & Soppeng & 164.64 & 3 & 68 & 3 \\
\hline 7313 & South Sulawesi & Wajo & 146.45 & 3 & 63 & 2 \\
\hline 7314 & South Sulawesi & Sidenreng Rappang & 127.40 & 3 & 66 & 2 \\
\hline 7315 & South Sulawesi & Pinrang & 174.46 & 3 & 66 & 2 \\
\hline 7316 & South Sulawesi & Enrekang & 97.21 & 2 & 67 & 3 \\
\hline 7317 & South Sulawesi & Luwu & 96.98 & 2 & 68 & 3 \\
\hline 7318 & South Sulawesi & Tana Toraja & 121.95 & 3 & 67 & 3 \\
\hline 7319 & South Sulawesi & Polewali Mamasa & 175.78 & 3 & 60 & 2 \\
\hline 7320 & South Sulawesi & Majene & 126.21 & 3 & 64 & 2 \\
\hline 7321 & South Sulawesi & Mamuju & 23.76 & 2 & 63 & 2 \\
\hline 7322 & South Sulawesi & Luwu Utara & 18.08 & 2 & 68 & 3 \\
\hline 7323 & South Sulawesi & Mamasa & 43.21 & 2 & & 1 \\
\hline 7401 & Southeast Sulawesi & Buton & 64.09 & 2 & 63 & 2 \\
\hline 7402 & Southeast Sulawesi & Muna & 64.35 & 2 & 61 & 2 \\
\hline 7403 & Southeast Sulawesi & Kendari & 15.39 & 2 & 65 & 2 \\
\hline 7404 & Southeast Sulawesi & Kolaka & 37.34 & 2 & 65 & 2 \\
\hline 7501 & Gorontalo & Boalemo & 16.27 & 2 & 64 & 2 \\
\hline 7502 & Gorontalo & Gorontalo & 70.23 & 2 & 65 & 2 \\
\hline 8101 & Maluku & Maluku Tenggara Barat & 14.89 & 2 & & 1 \\
\hline 8102 & Maluku & Maluku Tenggara & 18.17 & 2 & 63 & 2 \\
\hline 8103 & Maluku & Maluku Tengah & 27.05 & 2 & 67 & 3 \\
\hline 8104 & Maluku & Buru & 13.18 & 2 & 65 & 2 \\
\hline 8171 & Maluku & Ambon & 723.46 & 4 & 63 & 2 \\
\hline 8201 & North Maluku & Maluku Utara & 4.37 & 1 & 64 & 2 \\
\hline 8202 & North Maluku & Halmahera Tengah & 2.89 & 1 & 65 & 2 \\
\hline 9101 & Papua & Merauke & 3.26 & 1 & 58 & 2 \\
\hline 9102 & Papua & Jayawijaya & 10.49 & 2 & 47 & 1 \\
\hline 9104 & Papua & Nabire & 7.99 & 1 & 54 & 2 \\
\hline 9106 & Papua & Puncak Jaya & 4.48 & 1 & 66 & 2 \\
\hline 9107 & Papua & Fak-Fak & 4.86 & 1 & 64 & 2 \\
\hline 9108 & Papua & Mimika & 4.74 & 1 & 65 & 2 \\
\hline 9110 & Papua & Manokwari & 9.72 & 1 & 58 & 2 \\
\hline 9112 & Papua & Biak Numfor & 35.72 & 2 & 65 & 2 \\
\hline 9171 & Papua & Jayapura & 6.59 & 1 & 71 & 3 \\
\hline 9405 & Papua & Paniai & 8.11 & 1 & & 1 \\
\hline 9413 & Papua & Boven Digoel & 1.32 & 1 & & 1 \\
\hline 9414 & Papua & Mappi & 2.98 & 1 & & 1 \\
\hline 9415 & Papua & Asmat & 1.70 & 1 & & 1 \\
\hline 9416 & Papua & Yahukimo & 6.06 & 1 & & 1 \\
\hline 9417 & Papua & Pegunungan Bintang & 2.92 & 1 & & 1 \\
\hline 9418 & Papua & Tolikara & 6.25 & 1 & & 1 \\
\hline 9419 & Papua & Sarmi & 1.24 & 1 & & 1 \\
\hline 9420 & Papua & Keerom & 2.86 & 1 & & 1 \\
\hline 9421 & Papua & Kaimana & 2.04 & 1 & & 1 \\
\hline 9422 & Papua & Sorong & 4.05 & 1 & & 1 \\
\hline 9424 & Papua & Teluk Bintuni & 2.05 & 1 & & 1 \\
\hline 9425 & Papua & Teluk Wondama & 4.49 & 1 & & 1 \\
\hline 9426 & Papua & Waropen & 0.68 & 1 & & 1 \\
\hline
\end{tabular}


Appendix 3. Fire risk in CDM eligible land by district

\begin{tabular}{|c|c|c|c|c|c|}
\hline $\begin{array}{l}\text { District } \\
\text { Code }\end{array}$ & Province & District & District area (ha) & Fire Risk Index & Fire risk class \\
\hline 1101 & $\begin{array}{l}\text { Nanggroe Aceh } \\
\text { Darussalam }\end{array}$ & Simeulue & 207136.80 & 0.00740 & Few Fires \\
\hline 1102 & $\begin{array}{l}\text { Nanggroe Aceh } \\
\text { Darussalam }\end{array}$ & Aceh Singkil & 364225.11 & 0.05084 & Intermediate \\
\hline 1103 & $\begin{array}{l}\text { Nanggroe Aceh } \\
\text { Darussalam }\end{array}$ & Aceh Selatan & 398194.90 & 0.00494 & Few Fires \\
\hline 1104 & $\begin{array}{l}\text { Nanggroe Aceh } \\
\text { Darussalam }\end{array}$ & Aceh Tenggara & 483685.58 & 0.01165 & Few Fires \\
\hline 1105 & $\begin{array}{l}\text { Nanggroe Aceh } \\
\text { Darussalam }\end{array}$ & Aceh Timur & 592734.81 & 0.02260 & Few Fires \\
\hline 1106 & $\begin{array}{l}\text { Nanggroe Aceh } \\
\text { Darussalam }\end{array}$ & Aceh Tengah & 728881.53 & 0.02427 & Few Fires \\
\hline 1107 & $\begin{array}{l}\text { Nanggroe Aceh } \\
\text { Darussalam }\end{array}$ & Aceh Barat & 353416.14 & 0.01950 & Few Fires \\
\hline 1108 & $\begin{array}{l}\text { Nanggroe Aceh } \\
\text { Darussalam }\end{array}$ & Aceh Besar & 322745.27 & 0.06730 & Intermediate \\
\hline 1109 & $\begin{array}{l}\text { Nanggroe Aceh } \\
\text { Darussalam }\end{array}$ & Pidie & 471800.71 & 0.02013 & Few Fires \\
\hline 1110 & $\begin{array}{l}\text { Nanggroe Aceh } \\
\text { Darussalam }\end{array}$ & Bireuen & 190778.76 & 0.05647 & Intermediate \\
\hline 1111 & $\begin{array}{l}\text { Nanggroe Aceh } \\
\text { Darussalam }\end{array}$ & Aceh Utara & 269572.63 & 0.07750 & Intermediate \\
\hline 1112 & $\begin{array}{l}\text { Nanggroe Aceh } \\
\text { Darussalam }\end{array}$ & Aceh Barat Daya & 255660.67 & 0.00297 & Few Fires \\
\hline 1113 & $\begin{array}{l}\text { Nanggroe Aceh } \\
\text { Darussalam }\end{array}$ & Gayo Lues & 619822.88 & 0.01279 & Few Fires \\
\hline 1114 & $\begin{array}{l}\text { Nanggroe Aceh } \\
\text { Darussalam }\end{array}$ & Aceh Tamiang & 245743.08 & 0.03189 & Few Fires \\
\hline 1115 & $\begin{array}{l}\text { Nanggroe Aceh } \\
\text { Darussalam }\end{array}$ & Nagan Raya & 386546.21 & 0.03100 & Few Fires \\
\hline 1116 & $\begin{array}{l}\text { Nanggroe Aceh } \\
\text { Darussalam }\end{array}$ & Aceh Jaya & 431549.51 & 0.00581 & Few Fires \\
\hline 1201 & North Sumatra & Labuhan Batu & 1640953.25 & 0.16417 & Intermediate \\
\hline 1202 & North Sumatra & Mandailing Natal & 696569.90 & 0.03119 & Few Fires \\
\hline 1203 & North Sumatra & Tapanuli Selatan & 1307446.14 & 0.11537 & Intermediate \\
\hline 1204 & North Sumatra & Tapanuli Tengah & 264323.81 & 0.03609 & Few Fires \\
\hline 1205 & North Sumatra & Tapanuli Utara & 643672.70 & 0.02557 & Few Fires \\
\hline 1206 & North Sumatra & Toba Samosir & 408939.22 & 0.02069 & Few Fires \\
\hline 1208 & North Sumatra & Asahan & 510575.08 & 0.08149 & Intermediate \\
\hline 1209 & North Sumatra & Simalungun & 491690.76 & 0.07369 & Intermediate \\
\hline 1210 & North Sumatra & Dairi & 490829.72 & 0.00927 & Few Fires \\
\hline 1211 & North Sumatra & Karo & 241020.74 & 0.02173 & Few Fires \\
\hline 1212 & North Sumatra & Deli Serdang & 505664.32 & 0.05809 & Intermediate \\
\hline 1213 & North Sumatra & Langkat & 690264.40 & 0.05420 & Intermediate \\
\hline 1301 & West Sumatra & Kepulauan Mentawai & 653894.71 & 0.00059 & Few Fires \\
\hline 1302 & West Sumatra & Pesisir Selatan & 646016.65 & 0.04552 & Few Fires \\
\hline 1303 & West Sumatra & Solok & 737173.41 & 0.01038 & Few Fires \\
\hline 1304 & West Sumatra & Sawahlunto/Sijunjung & 628094.15 & 0.02546 & Few Fires \\
\hline 1305 & West Sumatra & Tanah Datar & 148490.41 & 0.00317 & Few Fires \\
\hline 1306 & West Sumatra & Padang Pariaman & 172836.37 & 0.00539 & Few Fires \\
\hline 1307 & West Sumatra & Agam & 246481.10 & 0.04982 & Few Fires \\
\hline 1308 & West Sumatra & Lima Puluh Koto & 311903.76 & 0.02063 & Few Fires \\
\hline 1309 & West Sumatra & Pasaman & 848442.67 & 0.04854 & Few Fires \\
\hline 1401 & Riau & Kuantan Singingi & 551732.96 & 0.19257 & Intermediate \\
\hline
\end{tabular}




\begin{tabular}{|c|c|c|c|c|c|}
\hline $\begin{array}{c}\text { District } \\
\text { Code }\end{array}$ & Province & District & District area (ha) & Fire Risk Index & Fire risk class \\
\hline 1402 & Riau & Indragiri Hulu & 838907.40 & 0.12862 & Intermediate \\
\hline 1403 & Riau & Indragiri Hilir & 1307633.56 & 0.15438 & Intermediate \\
\hline 1404 & Riau & Pelalawan & 1401268.48 & 0.10855 & Intermediate \\
\hline 1405 & Riau & Siak & 863634.29 & 0.17732 & Intermediate \\
\hline 1406 & Riau & Kampar & 1137858.96 & 0.30733 & Risk of Fire \\
\hline 1407 & Riau & Rokan Hulu & 822439.39 & 0.28686 & Risk of Fire \\
\hline 1408 & Riau & Bengkalis & 1246465.03 & 0.14916 & Intermediate \\
\hline 1409 & Riau & Rokan Hilir & 1023553.67 & 0.29930 & Risk of Fire \\
\hline 1410 & Riau & Kepulauan Riau & 429534.55 & 0.05318 & Intermediate \\
\hline 1411 & Riau & Karimun & 97662.68 & 0.07112 & Intermediate \\
\hline 1412 & Riau & Natuna & 283578.64 & 0.01532 & Few Fires \\
\hline 1501 & Jambi & Kerinci & 400131.71 & 0.01068 & Few Fires \\
\hline 1502 & Jambi & Merangin & 738899.17 & 0.05698 & Intermediate \\
\hline 1503 & Jambi & Sarolangun & 710660.03 & 0.12222 & Intermediate \\
\hline 1504 & Jambi & Batanghari & 615202.00 & 0.07827 & Intermediate \\
\hline 1505 & Jambi & Muara Jambi & 499349.49 & 0.19296 & Intermediate \\
\hline 1506 & Jambi & Tanjung Jabung Timur & 513253.38 & 0.17741 & Intermediate \\
\hline 1507 & Jambi & Tanjung Jabung Barat & 576664.70 & 0.10978 & Intermediate \\
\hline 1508 & Jambi & Tebo & 665371.30 & 0.08469 & Intermediate \\
\hline 1509 & Jambi & Bungo & 494431.13 & 0.11765 & Intermediate \\
\hline 1601 & South Sumatra & Ogan Komering Ulu & 1086604.10 & 0.23090 & Risk of Fire \\
\hline 1602 & South Sumatra & Ogan Komering Ilir & 2048356.30 & 0.47624 & Risk of Fire \\
\hline 1603 & South Sumatra & Muara Enim & 829422.74 & 0.42587 & Risk of Fire \\
\hline 1604 & South Sumatra & Lahat & 705651.78 & 0.12292 & Intermediate \\
\hline 1605 & South Sumatra & Musi Rawas & 1277002.45 & 0.14038 & Intermediate \\
\hline 1606 & South Sumatra & Musi Banyu Asin & 1585607.76 & 0.28009 & Risk of Fire \\
\hline 1607 & South Sumatra & Banyu Asin & 1251936.69 & 0.28789 & Risk of Fire \\
\hline 1701 & Bengkulu & Bengkulu Selatan & 768084.06 & 0.02533 & Few Fires \\
\hline 1702 & Bengkulu & Rejang Lebong & 408527.18 & 0.01491 & Few Fires \\
\hline 1703 & Bengkulu & Bengkulu Utara & 1041263.40 & 0.06685 & Intermediate \\
\hline 1801 & Lampung & Lampung Barat & 517041.45 & 0.01410 & Few Fires \\
\hline 1802 & Lampung & Tanggamus & 382668.92 & 0.01873 & Few Fires \\
\hline 1803 & Lampung & Lampung Selatan & 455843.85 & 0.04795 & Few Fires \\
\hline 1804 & Lampung & Lampung Timur & 291058.26 & 0.07094 & Intermediate \\
\hline 1805 & Lampung & Lampung Tengah & 456640.39 & 0.28230 & Risk of Fire \\
\hline 1806 & Lampung & Lampung Utara & 243742.53 & 0.31963 & Risk of Fire \\
\hline 1807 & Lampung & Way Kanan & 410099.67 & 0.37076 & Risk of Fire \\
\hline 1808 & Lampung & Tulang Bawang & 703463.38 & 0.60810 & Risk of Fire \\
\hline 1901 & $\begin{array}{l}\text { Kepulauan Bangka } \\
\text { - Belitung }\end{array}$ & Bangka & 325113.57 & 0.32501 & Risk of Fire \\
\hline 1902 & $\begin{array}{l}\text { Kepulauan Bangka } \\
\text { - Belitung }\end{array}$ & Belitung & 237577.60 & 0.21070 & Risk of Fire \\
\hline 1903 & $\begin{array}{l}\text { Kepulauan Bangka } \\
\text { - Belitung }\end{array}$ & Bangka Barat & 301859.58 & 0.27565 & Risk of Fire \\
\hline 1904 & $\begin{array}{l}\text { Kepulauan Bangka } \\
\text { - Belitung }\end{array}$ & Bangka Tengah & 206605.34 & 0.21481 & Risk of Fire \\
\hline 1905 & $\begin{array}{l}\text { Kepulauan Bangka } \\
\text { - Belitung }\end{array}$ & Bangka Selatan & 380391.77 & 0.36723 & Risk of Fire \\
\hline 1906 & $\begin{array}{l}\text { Kepulauan Bangka } \\
\text { - Belitung }\end{array}$ & Belitung Timur & 206839.20 & 0.28765 & Risk of Fire \\
\hline 3201 & West Java & Bogor & 306501.21 & 0.02854 & Few Fires \\
\hline 3202 & West Java & Sukabumi & 428466.81 & 0.10534 & Intermediate \\
\hline 3203 & West Java & Cianjur & 374097.10 & 0.04368 & Few Fires \\
\hline 3204 & West Java & Bandung & 314423.57 & 0.04306 & Few Fires \\
\hline 3205 & West Java & Garut & 315697.79 & 0.02315 & Few Fires \\
\hline
\end{tabular}




\begin{tabular}{|c|c|c|c|c|c|}
\hline $\begin{array}{c}\text { District } \\
\text { Code }\end{array}$ & Province & District & District area (ha) & Fire Risk Index & Fire risk class \\
\hline 3206 & West Java & Tasikmalaya & 281499.30 & 0.02431 & Few Fires \\
\hline 3207 & West Java & Ciamis & 277999.65 & 0.02700 & Few Fires \\
\hline 3208 & West Java & Kuningan & 124603.30 & 0.03616 & Few Fires \\
\hline 3209 & West Java & Cirebon & 107320.96 & 0.27399 & Risk of Fire \\
\hline 3210 & West Java & Majalengka & 134191.84 & 0.17779 & Intermediate \\
\hline 3211 & West Java & Sumedang & 161175.81 & 0.09369 & Intermediate \\
\hline 3212 & West Java & Indramayu & 209791.81 & 0.27442 & Risk of Fire \\
\hline 3213 & West Java & Subang & 221540.39 & 0.33725 & Risk of Fire \\
\hline 3214 & West Java & Purwakarta & 97552.26 & 0.12823 & Intermediate \\
\hline 3215 & West Java & Karawang & 198463.08 & 0.17011 & Intermediate \\
\hline 3216 & West Java & Bekasi & 129682.83 & 0.14331 & Intermediate \\
\hline 3301 & Central Java & Cilacap & 230901.89 & 0.07359 & Intermediate \\
\hline 3302 & Central Java & Banyumas & 142813.07 & 0.06857 & Intermediate \\
\hline 3303 & Central Java & Purbalingga & 82654.08 & 0.01172 & Few Fires \\
\hline 3304 & Central Java & Banjarnegara & 116285.67 & 0.02169 & Few Fires \\
\hline 3305 & Central Java & Kebumen & 134370.93 & 0.11462 & Intermediate \\
\hline 3306 & Central Java & Purworejo & 109490.47 & 0.04775 & Few Fires \\
\hline 3307 & Central Java & Wonosobo & 100524.85 & 0.00461 & Few Fires \\
\hline 3308 & Central Java & Magelang & 114516.40 & 0.01112 & Few Fires \\
\hline 3309 & Central Java & Boyolali & 110684.38 & 0.04099 & Few Fires \\
\hline 3310 & Central Java & Klaten & 67329.36 & 0.03068 & Few Fires \\
\hline 3311 & Central Java & Sukoharjo & 51552.72 & 0.10181 & Intermediate \\
\hline 3312 & Central Java & Wonogiri & 192492.99 & 0.07688 & Intermediate \\
\hline 3313 & Central Java & Karanganyar & 81928.14 & 0.05310 & Intermediate \\
\hline 3314 & Central Java & Sragen & 98172.85 & 0.13837 & Intermediate \\
\hline 3315 & Central Java & Grobogan/Purwodadi & 199907.44 & 0.13153 & Intermediate \\
\hline 3316 & Central Java & Blora & 196019.25 & 0.19347 & Intermediate \\
\hline 3317 & Central Java & Rembang & 106793.03 & 0.11953 & Intermediate \\
\hline 3318 & Central Java & Pati & 159835.08 & 0.22397 & Risk of Fire \\
\hline 3319 & Central Java & Kudus & 42716.52 & 0.14534 & Intermediate \\
\hline 3320 & Central Java & Jepara & 107735.78 & 0.08578 & Intermediate \\
\hline 3321 & Central Java & Demak & 98940.80 & 0.11888 & Intermediate \\
\hline 3322 & Central Java & Semarang & 102834.72 & 0.02858 & Few Fires \\
\hline 3323 & Central Java & Temanggung & 89169.68 & 0.00154 & Few Fires \\
\hline 3324 & Central Java & Kendal & 102536.39 & 0.10171 & Intermediate \\
\hline 3325 & Central Java & Batang & 75002.98 & 0.06859 & Intermediate \\
\hline 3326 & Central Java & Pekalongan & 98479.18 & 0.02466 & Few Fires \\
\hline 3327 & Central Java & Pemalang & 113752.32 & 0.16355 & Intermediate \\
\hline 3328 & Central Java & Tegal & 100231.03 & 0.16183 & Intermediate \\
\hline 3329 & Central Java & Brebes & 175972.27 & 0.10049 & Intermediate \\
\hline 3401 & DI Yogyakarta & Kulon Progo & 61078.55 & 0.01995 & Few Fires \\
\hline 3402 & DI Yogyakarta & Bantul & 49215.51 & 0.00462 & Few Fires \\
\hline 3403 & DI Yogyakarta & Gunung Kidul & 147688.46 & 0.03006 & Few Fires \\
\hline 3404 & DI Yogyakarta & Sleman & 57489.25 & 0.02424 & Few Fires \\
\hline 3501 & East Java & Pacitan & 142654.39 & 0.03761 & Few Fires \\
\hline 3502 & East Java & Ponorogo & 145047.39 & 0.09711 & Intermediate \\
\hline 3503 & East Java & Trenggalek & 125737.32 & 0.02080 & Few Fires \\
\hline 3504 & East Java & Tulungagung & 116385.54 & 0.01817 & Few Fires \\
\hline 3505 & East Java & Blitar & 174708.65 & 0.05547 & Intermediate \\
\hline 3506 & East Java & Kediri & 155319.75 & 0.10961 & Intermediate \\
\hline 3507 & East Java & Malang & 352940.15 & 0.02137 & Few Fires \\
\hline 3508 & East Java & Lumajang & 180980.53 & 0.05123 & Intermediate \\
\hline 3509 & East Java & Jember & 335953.15 & 0.02073 & Few Fires \\
\hline 3510 & East Java & Banyuwangi & 354447.18 & 0.04311 & Few Fires \\
\hline
\end{tabular}




\begin{tabular}{|c|c|c|c|c|c|}
\hline $\begin{array}{c}\text { District } \\
\text { Code }\end{array}$ & Province & District & District area (ha) & Fire Risk Index & Fire risk class \\
\hline 3511 & East Java & Bondowoso & 155520.77 & 0.12939 & Intermediate \\
\hline 3512 & East Java & Situbondo & 162309.65 & 0.25825 & Risk of Fire \\
\hline 3513 & East Java & Probolinggo & 172799.82 & 0.09344 & Intermediate \\
\hline 3514 & East Java & Pasuruan & 149398.52 & 0.15943 & Intermediate \\
\hline 3515 & East Java & Sidoarjo & 68652.83 & 0.25266 & Risk of Fire \\
\hline 3516 & East Java & Mojokerto & 100126.04 & 0.11069 & Intermediate \\
\hline 3517 & East Java & Jombang & 109693.59 & 0.17156 & Intermediate \\
\hline 3518 & East Java & Nganjuk & 128918.68 & 0.14777 & Intermediate \\
\hline 3519 & East Java & Madiun & 111557.63 & 0.13322 & Intermediate \\
\hline 3520 & East Java & Magetan & 72495.64 & 0.17128 & Intermediate \\
\hline 3521 & East Java & Ngawi & 140951.81 & 0.19512 & Intermediate \\
\hline 3522 & East Java & Bojonegoro & 236190.62 & 0.16171 & Intermediate \\
\hline 3523 & East Java & Tuban & 199037.73 & 0.26089 & Risk of Fire \\
\hline 3524 & East Java & Lamongan & 177649.76 & 0.21756 & Risk of Fire \\
\hline 3525 & East Java & Gresik & 122664.93 & 0.11644 & Intermediate \\
\hline 3526 & East Java & Bangkalan & 131131.14 & 0.07354 & Intermediate \\
\hline 3527 & East Java & Sampang & 123754.20 & 0.07737 & Intermediate \\
\hline 3528 & East Java & Pamekasan & 80533.92 & 0.03348 & Few Fires \\
\hline 3529 & East Java & Sumenep & 215965.81 & 0.05083 & Intermediate \\
\hline 3601 & Banten & Pandeglang & 289958.52 & 0.08778 & Intermediate \\
\hline 3602 & Banten & Lebak & 334960.96 & 0.08344 & Intermediate \\
\hline 3603 & Banten & Tangerang & 119173.30 & 0.08469 & Intermediate \\
\hline 3604 & Banten & Serang & 183015.16 & 0.15455 & Intermediate \\
\hline 5101 & Bali & Jembrana & 85823.87 & 0.01307 & Few Fires \\
\hline 5102 & Bali & Tabanan & 86909.80 & 0.00000 & Few Fires \\
\hline 5103 & Bali & Badung & 39293.99 & 0.00000 & Few Fires \\
\hline 5104 & Bali & Gianyar & 36477.31 & 0.00000 & Few Fires \\
\hline 5105 & Bali & Klungkung & 30972.19 & 0.00000 & Few Fires \\
\hline 5106 & Bali & Bangli & 52583.45 & 0.00000 & Few Fires \\
\hline 5107 & Bali & Karangasem & 86134.73 & 0.01756 & Few Fires \\
\hline 5108 & Bali & Buleleng & 133563.10 & 0.03132 & Few Fires \\
\hline 5201 & West Nusa Tenggara & Lombok Barat & 172380.29 & 0.01184 & Few Fires \\
\hline 5202 & West Nusa Tenggara & Lombok Tengah & 126292.85 & 0.02158 & Few Fires \\
\hline 5203 & West Nusa Tenggara & Lombok Timur & 150385.62 & 0.00000 & Few Fires \\
\hline 5204 & West Nusa Tenggara & Sumbawa & 837565.77 & 0.00277 & Few Fires \\
\hline 5205 & West Nusa Tenggara & Dompu & 218591.72 & 0.02646 & Few Fires \\
\hline 5206 & West Nusa Tenggara & Bima & 431425.32 & 0.01904 & Few Fires \\
\hline 5301 & East Nusa Tenggara & Sumba Barat & 392908.24 & 0.00000 & Few Fires \\
\hline 5302 & East Nusa Tenggara & Sumba Timur & 680117.12 & 0.00300 & Few Fires \\
\hline 5303 & East Nusa Tenggara & Kupang & 551793.53 & 0.00000 & Few Fires \\
\hline 5304 & East Nusa Tenggara & Timor Tengah Selatan & 401686.90 & 0.00000 & Few Fires \\
\hline 5305 & East Nusa Tenggara & Timor Tengah Utara & 268107.32 & 0.00000 & Few Fires \\
\hline 5306 & East Nusa Tenggara & Belu & 226307.06 & 0.00000 & Few Fires \\
\hline 5307 & East Nusa Tenggara & Alor & 296432.37 & 0.00090 & Few Fires \\
\hline 5308 & East Nusa Tenggara & Lembata & 127451.08 & 0.00361 & Few Fires \\
\hline 5309 & East Nusa Tenggara & Flores Timur & 178248.57 & 0.00123 & Few Fires \\
\hline 5310 & East Nusa Tenggara & Sikka & 179408.99 & 0.00000 & Few Fires \\
\hline 5311 & East Nusa Tenggara & Ende & 223173.15 & 0.00000 & Few Fires \\
\hline 5312 & East Nusa Tenggara & Ngada & 300446.53 & 0.00258 & Few Fires \\
\hline 5313 & East Nusa Tenggara & Manggarai & 690517.74 & 0.00053 & Few Fires \\
\hline 5314 & East Nusa Tenggara & Rote Ndao & 129459.90 & 0.00000 & Few Fires \\
\hline 6101 & West Kalimantan & Sambas & 597606.92 & 0.11005 & Intermediate \\
\hline 6102 & West Kalimantan & Bengkayang & 556461.70 & 0.10724 & Intermediate \\
\hline 6103 & West Kalimantan & Landak & 863235.80 & 0.40621 & Risk of Fire \\
\hline
\end{tabular}




\begin{tabular}{|c|c|c|c|c|c|}
\hline $\begin{array}{l}\text { District } \\
\text { Code }\end{array}$ & Province & District & District area (ha) & Fire Risk Index & Fire risk class \\
\hline 6104 & West Kalimantan & Pontianak & 1086192.77 & 0.13096 & Intermediate \\
\hline 6105 & West Kalimantan & Sanggau & 1871739.99 & 0.51242 & Risk of Fire \\
\hline 6106 & West Kalimantan & Ketapang & 3486219.35 & 0.26827 & Risk of Fire \\
\hline 6107 & West Kalimantan & Sintang & 3266001.17 & 0.34711 & Risk of Fire \\
\hline 6108 & West Kalimantan & Kapuas Hulu & 3096121.20 & 0.03509 & Few Fires \\
\hline 6201 & Central Kalimantan & Kotawaringin Barat & 1133284.48 & 0.18094 & Intermediate \\
\hline 6202 & Central Kalimantan & Kotawaringin Timur & 1620839.93 & 0.09985 & Intermediate \\
\hline 6203 & Central Kalimantan & Kapuas & 1487330.68 & 0.15345 & Intermediate \\
\hline 6204 & Central Kalimantan & Barito Selatan & 440520.79 & 0.07244 & Intermediate \\
\hline 6205 & Central Kalimantan & Barito Utara & 1131246.74 & 0.03383 & Few Fires \\
\hline 6206 & Central Kalimantan & Sukamara & 379524.15 & 0.37748 & Risk of Fire \\
\hline 6207 & Central Kalimantan & Lamandau & 491652.36 & 0.06033 & Intermediate \\
\hline 6208 & Central Kalimantan & Seruyan & 1442729.86 & 0.11137 & Intermediate \\
\hline 6209 & Central Kalimantan & Katingan & 2079164.94 & 0.03271 & Few Fires \\
\hline 6210 & Central Kalimantan & Pulang Pisau & 1168506.44 & 0.42309 & Risk of Fire \\
\hline 6211 & Central Kalimantan & Gunung Mas & 859684.13 & 0.06356 & Intermediate \\
\hline 6212 & Central Kalimantan & Barito Timur & 386628.67 & 0.24086 & Risk of Fire \\
\hline 6213 & Central Kalimantan & Murung Raya & 2417461.28 & 0.01809 & Few Fires \\
\hline 6301 & South Kalimantan & Tanah Laut & 385743.46 & 0.36956 & Risk of Fire \\
\hline 6302 & South Kalimantan & Kota Baru & 1427631.57 & 0.11113 & Intermediate \\
\hline 6303 & South Kalimantan & Banjar & 482190.86 & 0.26536 & Risk of Fire \\
\hline 6304 & South Kalimantan & Barito Kuala & 233661.47 & 0.35020 & Risk of Fire \\
\hline 6305 & South Kalimantan & Tapin & 216893.93 & 0.37698 & Risk of Fire \\
\hline 6306 & South Kalimantan & Hulu Sungai Selatan & 165397.75 & 0.54555 & Risk of Fire \\
\hline 6307 & South Kalimantan & Hulu Sungai Tengah & 118848.64 & 0.08083 & Intermediate \\
\hline 6308 & South Kalimantan & Hulu Sungai Utara & 293569.96 & 0.22719 & Risk of Fire \\
\hline 6309 & South Kalimantan & Tabalong & 361561.78 & 0.11134 & Intermediate \\
\hline 6401 & East Kalimantan & Pasir & 1085759.13 & 0.09435 & Intermediate \\
\hline 6402 & East Kalimantan & Kutai Barat & 3431876.14 & 0.06168 & Intermediate \\
\hline 6403 & East Kalimantan & Kutai Kertanegara & 2617197.75 & 0.09978 & Intermediate \\
\hline 6404 & East Kalimantan & Kutai Timur & 2835565.79 & 0.04551 & Few Fires \\
\hline 6405 & East Kalimantan & Berau & 2113705.09 & 0.01281 & Few Fires \\
\hline 6406 & East Kalimantan & Malinau & 3854502.72 & 0.00059 & Few Fires \\
\hline 6407 & East Kalimantan & Bulongan & 1581043.95 & 0.00983 & Few Fires \\
\hline 6408 & East Kalimantan & Nunukan & 1583268.28 & 0.00082 & Few Fires \\
\hline 6409 & East Kalimantan & Penajam Paser Utara & 336955.44 & 0.06636 & Intermediate \\
\hline 7101 & North Sulawesi & Bolaang Mengondow & 782361.51 & 0.00177 & Few Fires \\
\hline 7102 & North Sulawesi & Minahasa & 451686.25 & 0.00816 & Few Fires \\
\hline 7103 & North Sulawesi & $\begin{array}{l}\text { Kepulauan Sangihe } \\
\text { Talaud }\end{array}$ & 92188.71 & 0.00002 & Few Fires \\
\hline 7104 & North Sulawesi & Kepulauan Talaud & 105007.05 & 0.00000 & Few Fires \\
\hline 7201 & Central Sulawesi & Banggai Kepulauan & 316194.64 & 0.00774 & Few Fires \\
\hline 7202 & Central Sulawesi & Banggai & 909612.95 & 0.00301 & Few Fires \\
\hline 7203 & Central Sulawesi & Morowali & 1306925.84 & 0.01889 & Few Fires \\
\hline 7204 & Central Sulawesi & Poso & 1192920.97 & 0.01318 & Few Fires \\
\hline 7205 & Central Sulawesi & Donggala & 936916.68 & 0.00394 & Few Fires \\
\hline 7206 & Central Sulawesi & Toli-Toli & 361970.94 & 0.00000 & Few Fires \\
\hline 7207 & Central Sulawesi & Buol & 401081.13 & 0.00266 & Few Fires \\
\hline 7208 & Central Sulawesi & Parigi Moutong & 628871.45 & 0.00622 & Few Fires \\
\hline 7301 & South Sulawesi & Selayar & 121445.57 & 0.03052 & Few Fires \\
\hline 7302 & South Sulawesi & Bulukumba & 114787.00 & 0.02266 & Few Fires \\
\hline 7303 & South Sulawesi & Bantaeng & 39130.42 & 0.05534 & Intermediate \\
\hline 7304 & South Sulawesi & Jeneponto & 67073.50 & 0.19883 & Intermediate \\
\hline 7305 & South Sulawesi & Takalar & 63882.50 & 0.18438 & Intermediate \\
\hline
\end{tabular}




\begin{tabular}{|c|c|c|c|c|c|}
\hline $\begin{array}{c}\text { District } \\
\text { Code }\end{array}$ & Province & District & District area (ha) & Fire Risk Index & Fire risk class \\
\hline 7306 & South Sulawesi & Gowa & 175826.86 & 0.08686 & Intermediate \\
\hline 7307 & South Sulawesi & Sinjai & 85161.17 & 0.00365 & Few Fires \\
\hline 7308 & South Sulawesi & Maros & 160650.80 & 0.06646 & Intermediate \\
\hline 7309 & South Sulawesi & Pangkajene Kepulauan & 96301.76 & 0.01064 & Few Fires \\
\hline 7310 & South Sulawesi & Barru & 118038.53 & 0.02074 & Few Fires \\
\hline 7311 & South Sulawesi & Bone & 454959.76 & 0.09922 & Intermediate \\
\hline 7312 & South Sulawesi & Soppeng & 136237.24 & 0.04042 & Few Fires \\
\hline 7313 & South Sulawesi & Wajo & 247660.72 & 0.06559 & Intermediate \\
\hline 7314 & South Sulawesi & Sidenreng Rappang & 193180.38 & 0.05336 & Intermediate \\
\hline 7315 & South Sulawesi & Pinrang & 190039.08 & 0.01414 & Few Fires \\
\hline 7316 & South Sulawesi & Enrekang & 180852.48 & 0.00800 & Few Fires \\
\hline 7317 & South Sulawesi & Luwu & 312644.37 & 0.01208 & Few Fires \\
\hline 7318 & South Sulawesi & Tana Toraja & 341646.47 & 0.02011 & Few Fires \\
\hline 7319 & South Sulawesi & Polewali Mamasa & 199879.16 & 0.01140 & Few Fires \\
\hline 7320 & South Sulawesi & Majene & 102020.79 & 0.01157 & Few Fires \\
\hline 7321 & South Sulawesi & Mamuju & 1049566.31 & 0.00318 & Few Fires \\
\hline 7322 & South Sulawesi & Luwu Utara & 1490796.59 & 0.00710 & Few Fires \\
\hline 7323 & South Sulawesi & Mamasa & 273979.94 & 0.02029 & Few Fires \\
\hline 7401 & Southeast Sulawesi & Buton & 693722.57 & 0.07860 & Intermediate \\
\hline 7402 & Southeast Sulawesi & Muna & 444887.83 & 0.04136 & Few Fires \\
\hline 7403 & Southeast Sulawesi & Kendari & 1609999.56 & 0.04192 & Few Fires \\
\hline 7404 & Southeast Sulawesi & Kolaka & 927909.94 & 0.01145 & Few Fires \\
\hline 7501 & Gorontalo & Boalemo & 638481.28 & 0.01025 & Few Fires \\
\hline 7502 & Gorontalo & Gorontalo & 579720.74 & 0.01001 & Few Fires \\
\hline 8101 & Maluku & Maluku Tenggara Barat & 944052.12 & 0.00000 & Few Fires \\
\hline 8102 & Maluku & Maluku Tenggara & 1027840.28 & 0.00000 & Few Fires \\
\hline 8103 & Maluku & Maluku Tengah & 2033066.75 & 0.00003 & Few Fires \\
\hline 8104 & Maluku & Buru & 891900.93 & 0.01068 & Few Fires \\
\hline 8171 & Maluku & Ambon & 30833.39 & 0.00000 & Few Fires \\
\hline 8201 & North Maluku & Maluku Utara & 2152622.03 & 0.00008 & Few Fires \\
\hline 8202 & North Maluku & Halmahera Tengah & 1096252.73 & 0.00007 & Few Fires \\
\hline 9101 & Papua & Merauke & 5174572.66 & 0.00000 & Few Fires \\
\hline 9102 & Papua & Jayawijaya & 1775305.39 & 0.00000 & Few Fires \\
\hline 9104 & Papua & Nabire & 1902478.81 & 0.00000 & Few Fires \\
\hline 9106 & Papua & Puncak Jaya & 1456299.76 & 0.00000 & Few Fires \\
\hline 9107 & Papua & Fak-Fak & 1187456.74 & 0.00000 & Few Fires \\
\hline 9108 & Papua & Mimika & 2449449.30 & 0.00000 & Few Fires \\
\hline 9110 & Papua & Manokwari & 1537108.74 & 0.00000 & Few Fires \\
\hline 9112 & Papua & Biak Numfor & 346336.46 & 0.00000 & Few Fires \\
\hline 9171 & Papua & Jayapura & 1430215.90 & 0.00000 & Few Fires \\
\hline 9405 & Papua & Paniai & 1244760.99 & 0.00000 & Few Fires \\
\hline 9413 & Papua & Boven Digoel & 2876588.58 & 0.00000 & Few Fires \\
\hline 9414 & Papua & Mappi & 2270697.97 & 0.00000 & Few Fires \\
\hline 9415 & Papua & Asmat & 3681256.78 & 0.00000 & Few Fires \\
\hline 9416 & Papua & Yahukimo & 1821982.02 & 0.00000 & Few Fires \\
\hline 9417 & Papua & Pegunungan Bintang & 1911412.45 & 0.00000 & Few Fires \\
\hline 9418 & Papua & Tolikara & 643303.26 & 0.00000 & Few Fires \\
\hline 9419 & Papua & Sarmi & 2923724.29 & 0.00000 & Few Fires \\
\hline 9420 & Papua & Keerom & 1212944.47 & 0.00000 & Few Fires \\
\hline 9421 & Papua & Kaimana & 1767661.90 & 0.00000 & Few Fires \\
\hline 9422 & Papua & Sorong & 1412621.57 & 0.00000 & Few Fires \\
\hline 9424 & Papua & Teluk Bintuni & 2254368.37 & 0.00000 & Few Fires \\
\hline 9425 & Papua & Teluk Wondama & 443712.49 & 0.00000 & Few Fires \\
\hline 9426 & Papua & Waropen & 3137820.95 & 0.00000 & Few Fires \\
\hline
\end{tabular}


Appendix 4. Land cover classification at $1 \mathrm{~km}$ nominal spatial resolution for Indonesia according to the IGBP legend based on imagery of the 1992-1993 period (Hadi and van Noordwijk 2005).

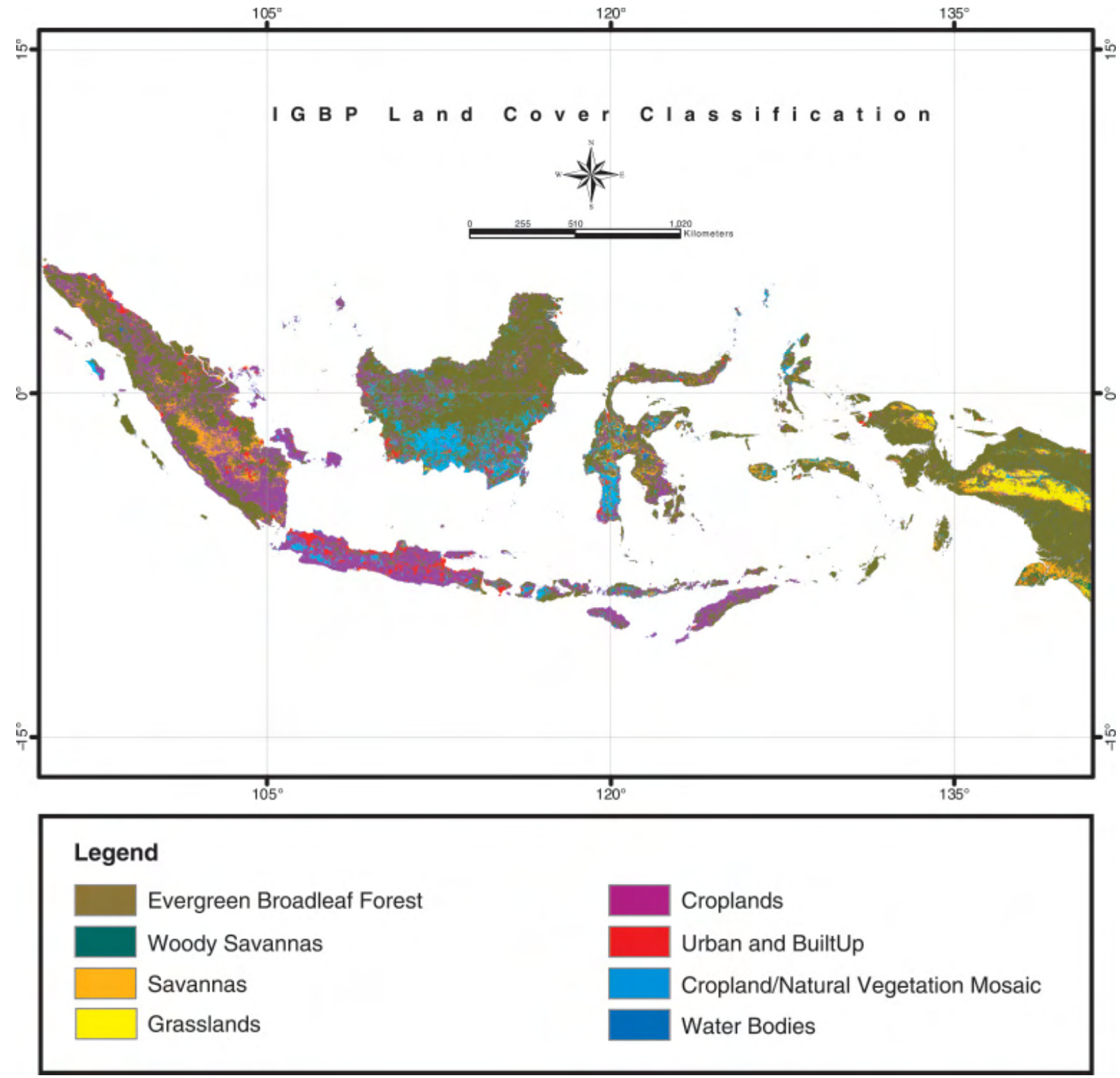


Appendix 5. Land cover classification for Indonesia's islands (excluding the seas) according to the IGBP legend (Source: Loveland et al. 1998)

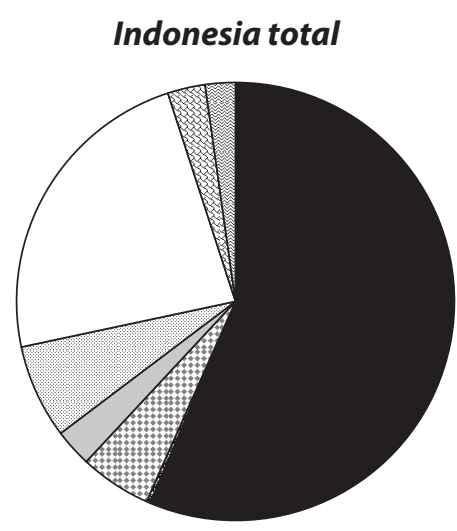

- Evergreen Broadleaf Forest

图 Woody Savannas

曰 Savannas

$\square$ Grasslands

Cropland/Natural Vegetation Mosaic

$\checkmark$ Croplands

圆 Urban and BuiltUp

图 Water Bodies

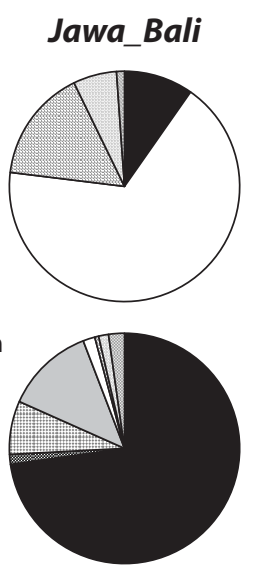

Papua

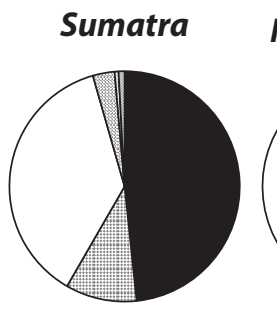

NTT_NTB_Mal
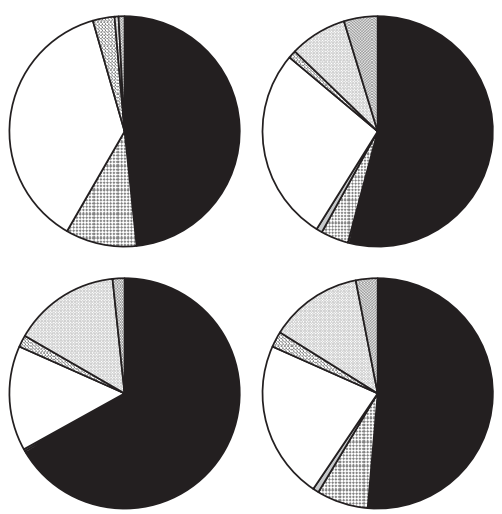

Kalimantan

Sulawesi 
Appendix 6. Workbook for applying specified prioritisation criteria to a list of district level statistics of land cover, fire frequency, population density and Human Development Index

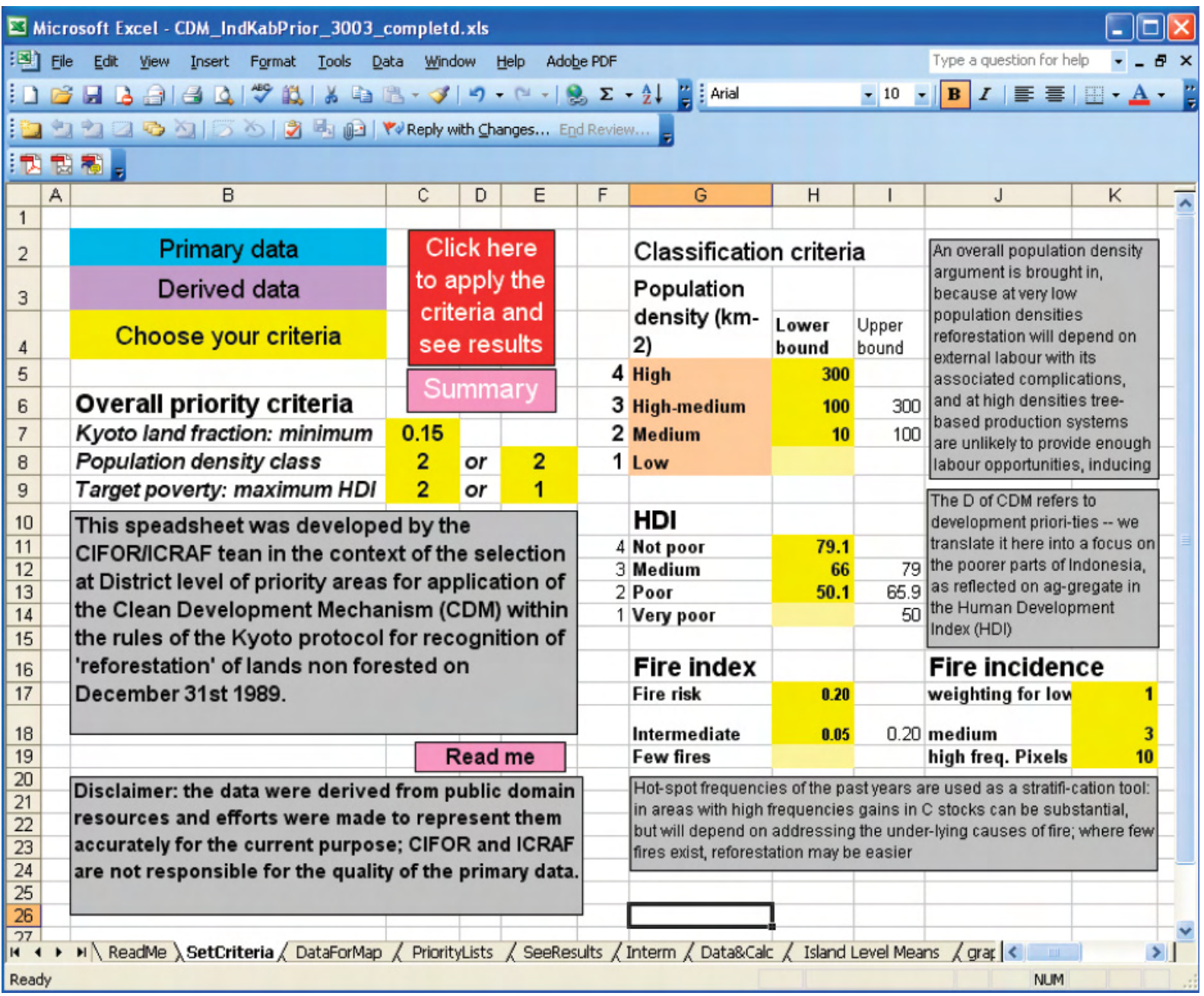



The Center for International Forestry Research (CIFOR) is a leading international forestry research organization established in 1993 in response to global concerns about the social, environmental, and economic consequences of forest loss and degradation. CIFOR is dedicated to developing policies and technologies for sustainable use and management of forests, and for enhancing the well-being of people in developing countries who rely on tropical forests for their livelihoods. CIFOR is one of the 15 Future Harvest centres of the Consultative Group on International Agricultural Research (CGIAR). With headquarters in Bogor, Indonesia, CIFOR has regional offices in Brazil, Burkina Faso, Cameroon and Zimbabwe, and it works in over 30 other countries around the world.

\section{Donors}

The Center for International Forestry Research (CIFOR) receives its major funding from governments, international development organizations, private foundations and regional organizations. In 2005, CIFOR received financial support from Australia, Asian Development Bank (ADB), Belgium, Brazil, Canada, China, Centre de coopération internationale en recherche agronomique pour le développement (CIRAD), Cordaid, Conservation International Foundation (CIF), European Commission, Finland, Food and Agriculture Organization of the United Nations (FAO), Ford Foundation, France, German Agency for Technical Cooperation (GTZ), German Federal Ministry for Economic Cooperation and Development (BMZ), Indonesia, International Development Research Centre (IDRC), International Fund for Agricultural Development (IFAD), International Tropical Timber Organization (ITTO), Israel, Italy, The World Conservation Union (IUCN), Japan, Korea, Netherlands, Norway, Netherlands Development Organization, Overseas Development Institute (ODI), Peruvian Secretariat for International Cooperation (RSCl), Philippines, Spain, Sweden, Swedish University of Agricultural Sciences (SLU), Switzerland, Swiss Agency for the Environment, Forests and Landscape, The Overbrook Foundation, The Nature Conservancy (TNC), Tropical Forest Foundation, Tropenbos International, United States, United Kingdom, United Nations Environment Programme (UNEP), World Bank, World Resources Institute (WRI) and World Wildlife Fund (WWF). 
Before a Project Design Document (PDD) can be developed, the eligibility of lands on which the afforestation and reforestation (A/R) Clean Development Mechanism (CDM) project activities are to be established has to be secured. This report describes the development of the 'hard criteria', which were used to determine the area and location of such lands with respect to administration at District or Kabupaten level in Indonesia. The criteria follow the decision on modalities and procedures of the Conference of Parties (COP) to the United Nations Framework Convention on Climate Change (UNFCCC) in their ninth sessions (Decision 19/CP.9).

Further screening is suggested to prioritize project implementation on eligible lands by considering the socio-economic and biophysical constraints. The 'soft criteria', which consist of population density, human development index (HDI) and fire risk were introduced. This means districts with low population density, low HDI and low fire risk may be prioritized.

From the host countries' perspectives it is imperative that projects meet the sustainable development objectives stipulated in the dual objectives of the CDM. The site selection criteria is 'pro-poor' as expressed by the low HDI prioritization. It is recommended, however, that the preparedness of stakeholders in the prioritized districts be assessed. Likewise, the legal instruments and institutional arrangement should be able to support the implementation of the projects.
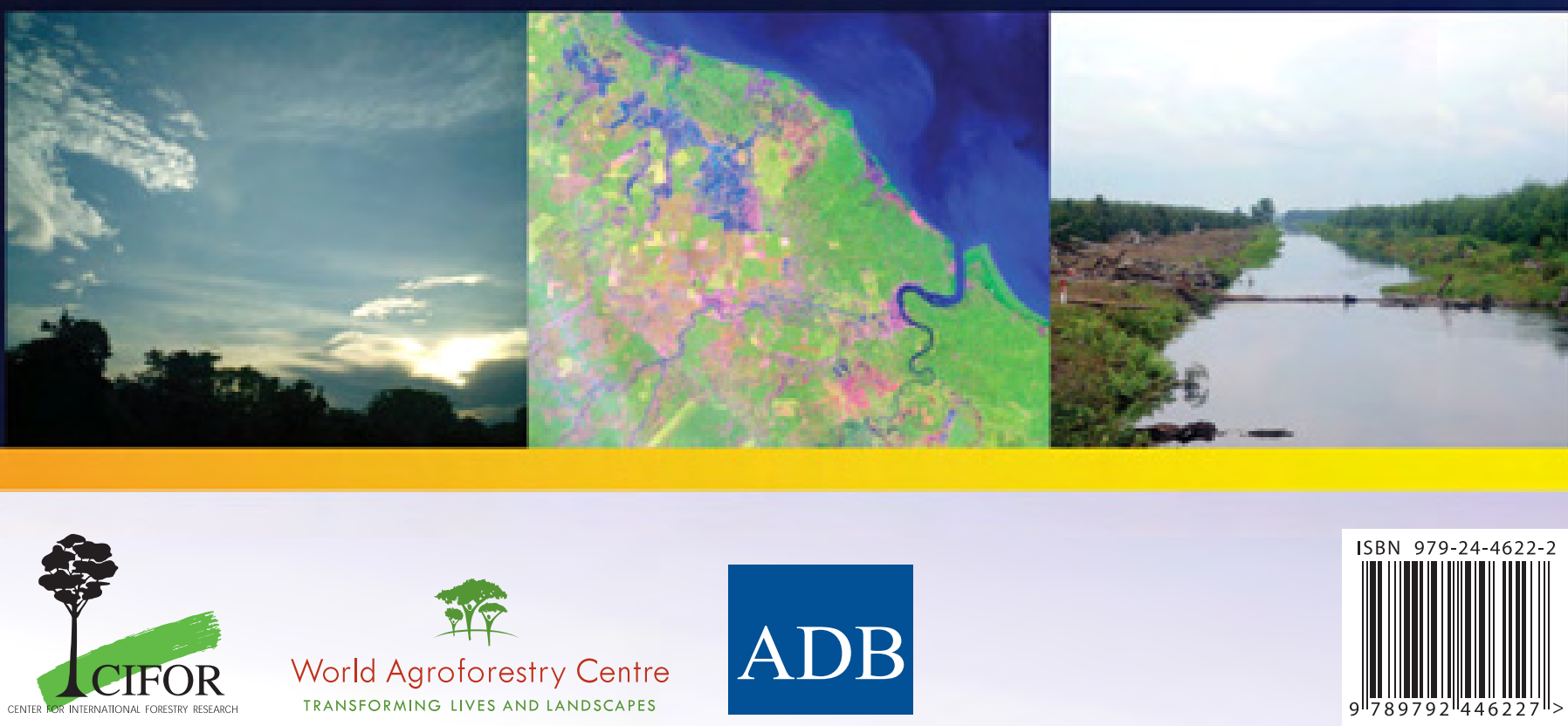